\title{
The Eli Moores Site, a 17th to early 18th Century Caddo Site on the Red River, Bowie County, Texas
}

Timothy K. Perttula

Heritage Research Center, Stephen F. Austin State University

Follow this and additional works at: https://scholarworks.sfasu.edu/ita

Part of the American Material Culture Commons, Archaeological Anthropology Commons, Environmental Studies Commons, Other American Studies Commons, Other Arts and Humanities Commons, Other History of Art, Architecture, and Archaeology Commons, and the United States History Commons

Tell us how this article helped you.

This Article is brought to you for free and open access by the Center for Regional Heritage Research at SFA ScholarWorks. It has been accepted for inclusion in Index of Texas Archaeology: Open Access Gray Literature from the Lone Star State by an authorized editor of SFA ScholarWorks. For more information, please contact cdsscholarworks@sfasu.edu. 
The Eli Moores Site, a 17th to early 18th Century Caddo Site on the Red River, Bowie County, Texas

\section{Creative Commons License}

\section{(c) (1) \&}

This work is licensed under a Creative Commons Attribution-NonCommercial 4.0 International License 


\section{The Eli Moores Site, a 17th to early 18th Century Caddo Site on the Red River, Bowie County, Texas}

\section{Edited by Timothy K. Perttula}

with contributions by Leslie L. Bush, Timothy K. Perttula, and Robert Z. Selden Jr.

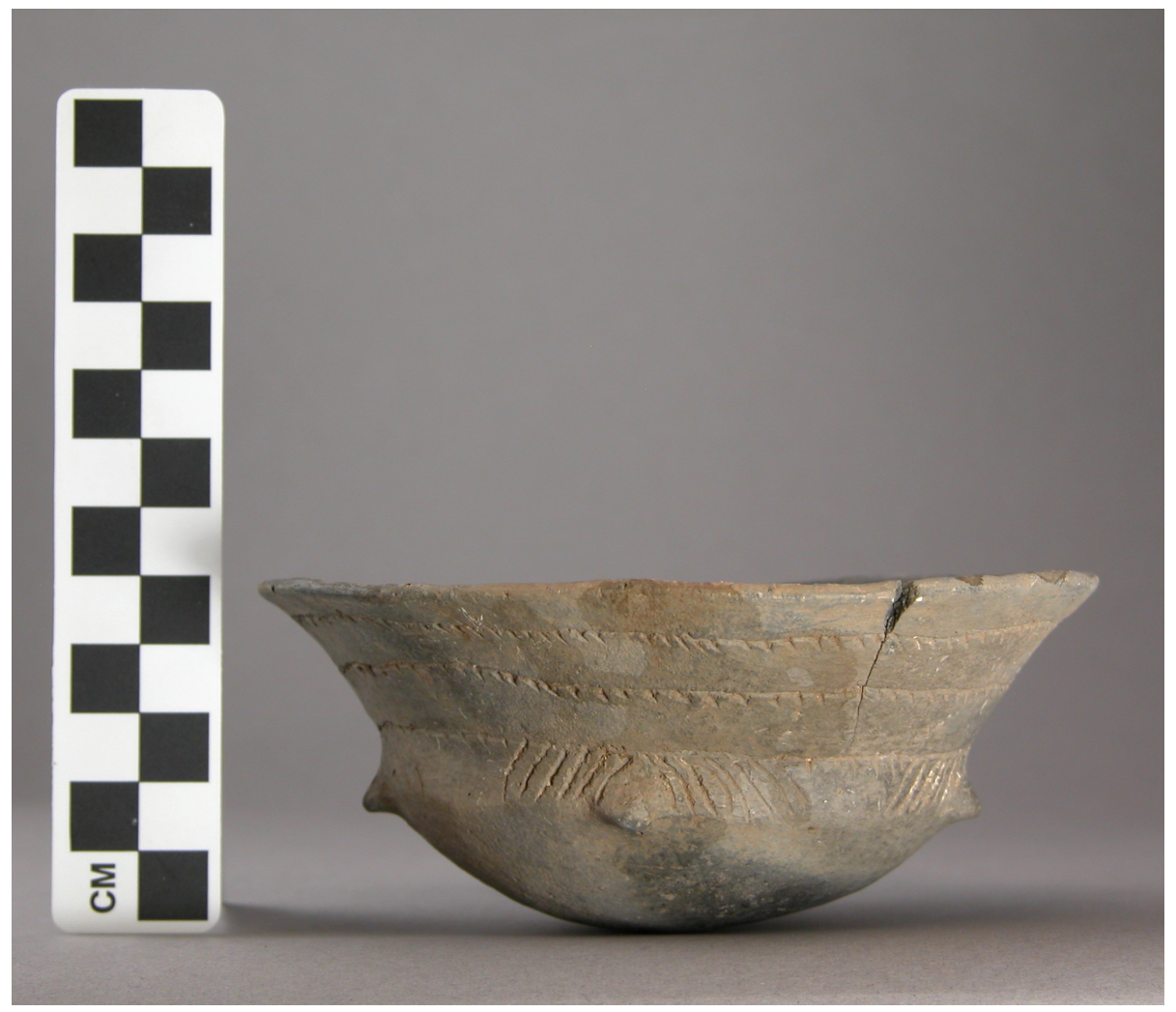

Special Publication No. 31

Friends of Northeast Texas Archaeology 
Distribution, Bo Nelson, 344 CR 4154

Pittsburg, Texas 75686

RBoNelson@aol.com

\section{Cover art:}

Belcher Engraved, var. Belcher compound bowl from Burial J-4

Copyright (C) 2014, Friends of Northeast Texas Archaeology

(Austin and Pittsburg) 


\section{Table of Contents}

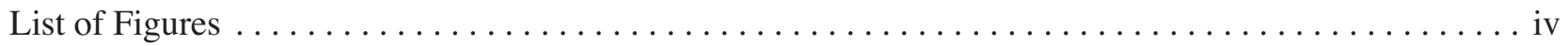

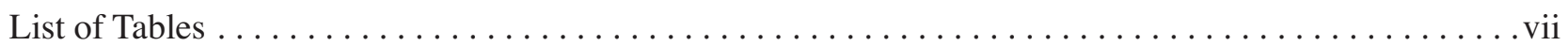

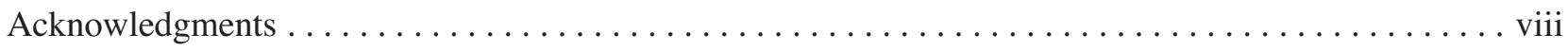

Chapter 1 , Introduction and Purpose of the Investigations $\ldots \ldots \ldots \ldots \ldots \ldots \ldots \ldots \ldots \ldots \ldots \ldots \ldots$

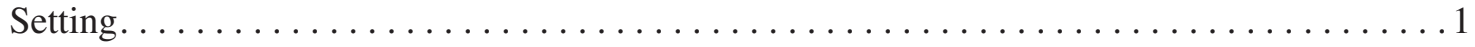

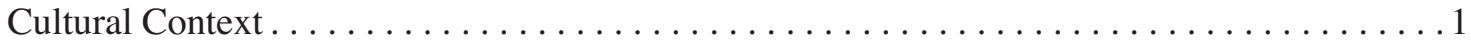

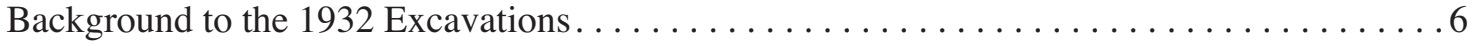

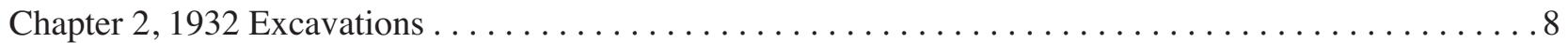

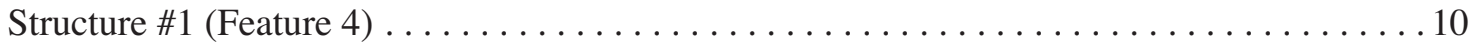

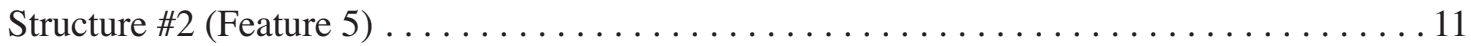

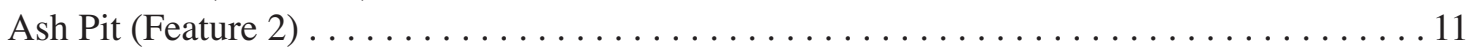

Burials in the Mound . . . . . . . . . . . . . . . . . . . . . . . . . . 11

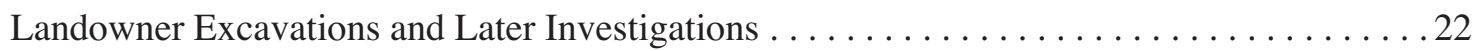

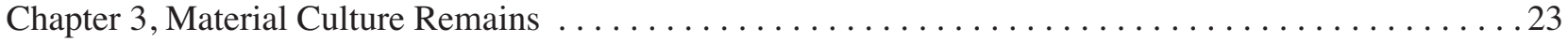

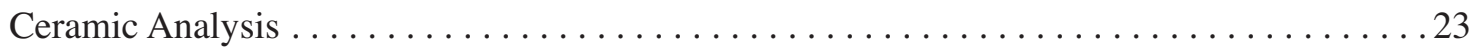

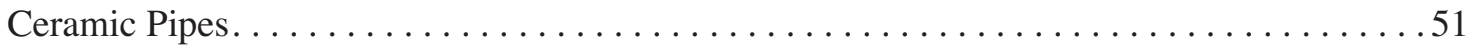

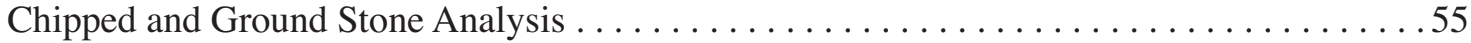

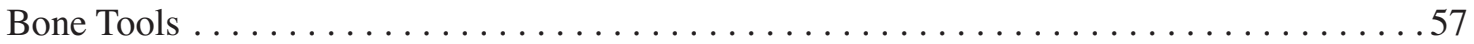

Mussel Shell Tools, Ornaments, and Unmodified Mussel Shells. . . . . . . . . . . . . . . . . 58

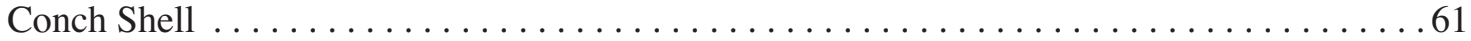

European Trade Goods . . . . . . . . . . . . . . . . . . . . . . . . . . .61

Chapter 4, Analysis of the Plant Remains from the Eli Moores Site (41BW2) . . . . . . . . . . 62

Eli Moores Site (41BW2) Plant Remains, Leslie L. Bush . . . . . . . . . . . . . . . . . 63

Chapter 5, Radiocarbon Dating, Timothy K. Perttula and Robert Z. Selden Jr. . . . . . . . . . . . . . 74

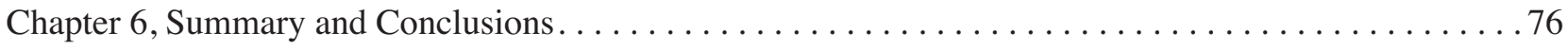

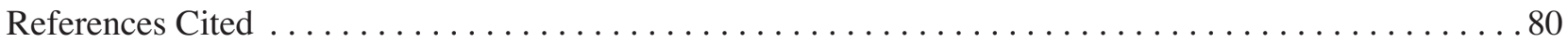




\section{List of Figures}

1. Aerial photograph of the Red River alluvial bottomlands in the area of the Eli Moores (41BW2) and Hatchel (41BW3) sites . . . . . . . . . . . . . . . . . . . . . . . 2

2. Caddo settlement areas in the southern Caddo area at ca. A.D. 1690 (after Barr 2011:Figure IV) . . . 3

3. Important Caddo archaeological sites along the Red River in the vicinity of the Eli Moores site . . . .4

4. The 1691 Teran map. Original in the J. P. Bryan Map Collection, CT0108, Center for American

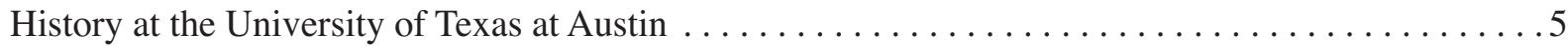

5. The mounds at the Eli Moores site, along with midden areas and 1902 and 1931 areas of burials

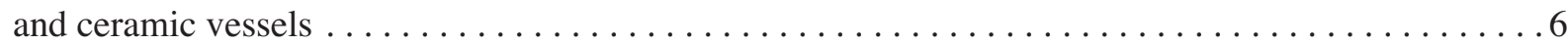

6. Plan of mounds, borrow pits, and one midden area at the Eli Moores site $\ldots \ldots \ldots \ldots \ldots \ldots$

7. Jackson's plan map of excavated areas in Mound \#1 at the Eli Moores site, and locations of burials, structures $1-2$, and various artifact find spots $\ldots \ldots \ldots \ldots \ldots \ldots \ldots \ldots \ldots \ldots \ldots \ldots \ldots \ldots \ldots \ldots \ldots$

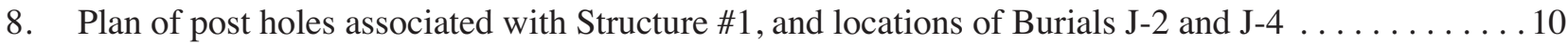

9. Close-up of the cane matting and pecan nutshell cache in Structure \#1 at the Eli Moores site . . . . 11

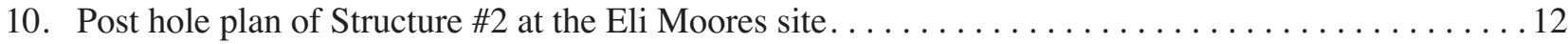

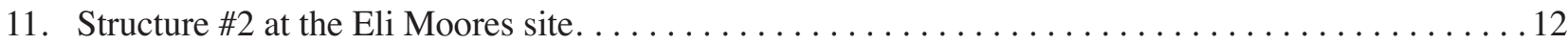

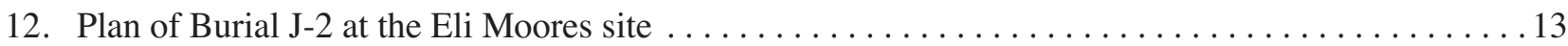

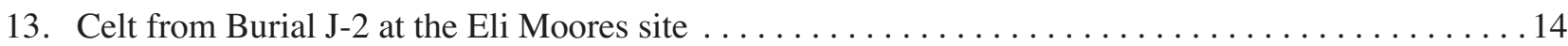

14. Taylor Engraved vessel section in Burial J-2 at the Eli Moores site $\ldots \ldots \ldots \ldots \ldots \ldots \ldots \ldots$

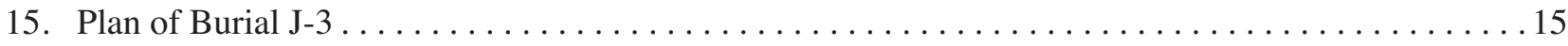

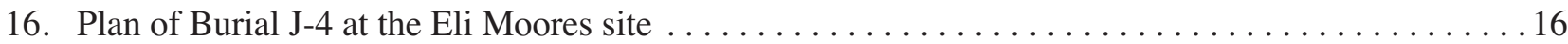

17. Arrow points in burials from the Eli Moores site: a-b, Burial J-8, Skeleton 2; c, Burial J-8,

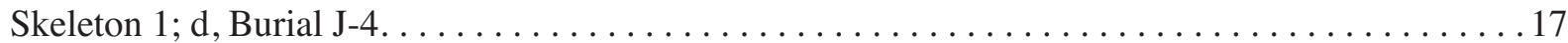

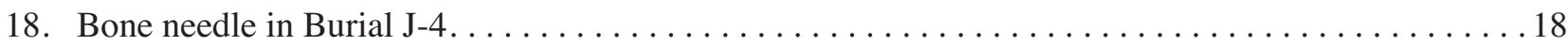

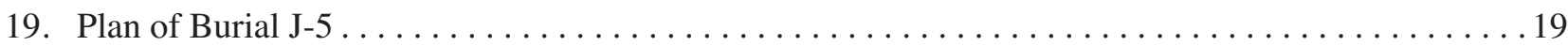

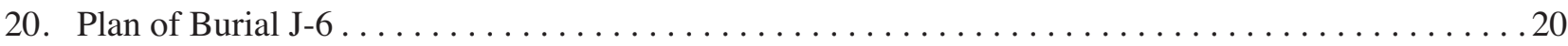

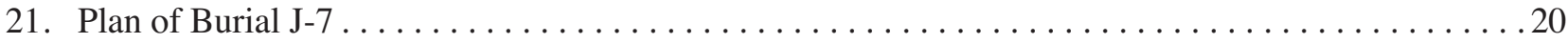

22. Barkman Engraved vessel section design elements $\ldots \ldots \ldots \ldots \ldots \ldots \ldots \ldots \ldots \ldots \ldots \ldots \ldots \ldots$

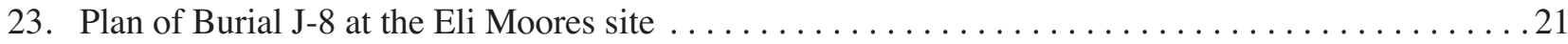

24. Drilled Turtle shell from Burial J-8, Skeleton $1 \ldots \ldots \ldots \ldots \ldots \ldots \ldots \ldots \ldots \ldots \ldots \ldots \ldots \ldots \ldots \ldots$

25. Plain ware vessels from the Eli Moores site: a, bowl or jar, Burial J-7; b, Artifact \#88,

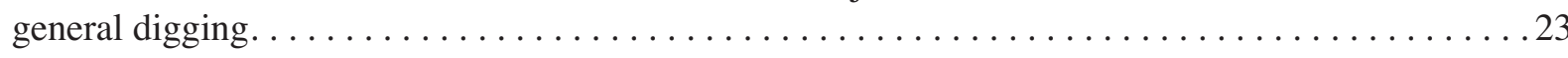

26. Utility ware vessels from the Eli Moores site: a, incised-punctated jar, Burial J-2; b, appliqued jar from Burial J-5; c, lower body section of Karnack Brushed-Incised jar . . . . . . . . . 24 
27. Fine ware vessels from the Eli Moores site: a, Simms Engraved carinated bowl, Burial J-2; b, Engraved bottle from Burial J-4; c, Belcher Engraved, var. Belcher compound bowl from Burial J-4; d, Barkman Engraved carinated bowl from Burial J-8; e, Barkman Engraved

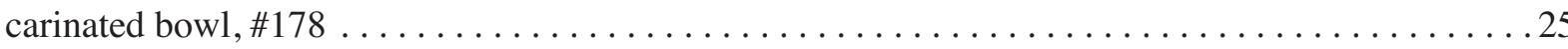

28. Utility ware rim and body sherds from the Eli Moores site: a, brushed-punctated-appliqued; b, i, incised; c, l, incised-appliqued; d, f, k, appliqued; e, tool punctated; g, brushed-punctated;

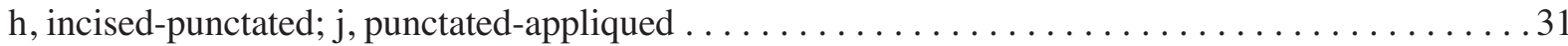

29. Utility ware vessel sections from the Eli Moores site: a, Brushed-punctated-incised jar vessel

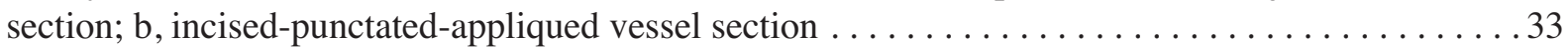

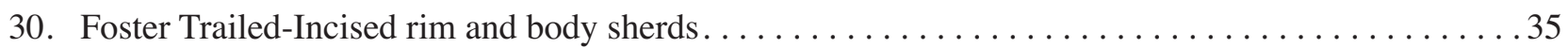

31. Cowhide Stamped vessel section from the fill of Burial J-7 $\ldots \ldots \ldots \ldots \ldots \ldots \ldots \ldots \ldots \ldots \ldots \ldots \ldots$

32. Foster Trailed-Incised vessel section from the Eli Moores site $\ldots \ldots \ldots \ldots \ldots \ldots \ldots \ldots \ldots \ldots$

33. Decorative elements on Simms Engraved rim sherds $\ldots \ldots \ldots \ldots \ldots \ldots \ldots \ldots \ldots \ldots \ldots \ldots$

34. Different engraved decorative elements on Simms Engraved rim panels . . . . . . . . . . . 41

35. Decorative elements on Barkman Engraved rim sherds $\ldots \ldots \ldots \ldots \ldots \ldots \ldots \ldots \ldots \ldots \ldots \ldots \ldots$

36. Decorative elements on Barkman Engraved lower rim sherds from carinated bowls . . . . . . . . 43

37. Avery Engraved and Taylor Engraved sherds: a, Avery Engraved compound bowl; b-c,

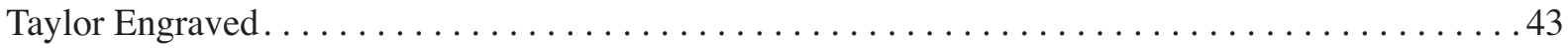

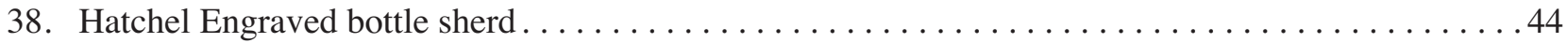

39. Hodges Engraved and Natchitoches Engraved decorative elements on sherds . . . . . . . . . . 44

40. Rim and body sherds from the Eli Moores site with engraved scroll elements . . . . . . . . . 46

41. Rim and body sherds with scroll elements and broad cross-hatched engraved zones. . . . . . . . 47

42. Decorative elements on engraved bottle sherds at the Eli Moores site $\ldots \ldots \ldots \ldots \ldots \ldots \ldots$

43. Engraved-appliqued sherds: a, Engraved-appliqued vessel section; b-c, Belcher Engraved . . . . . . 49

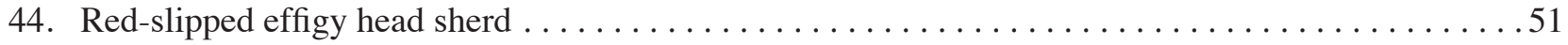

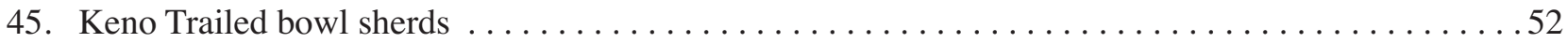

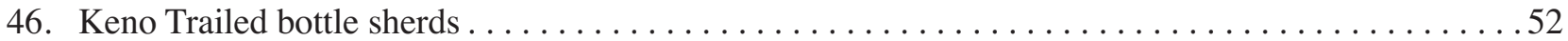

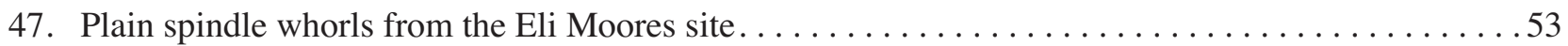

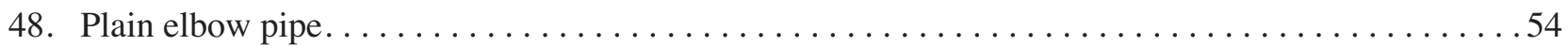

49. Other clay pipes from the Eli Moores site: a, elbow pipe; b, triangular-shaped pipe;

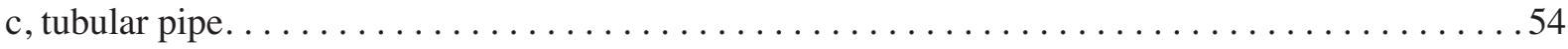

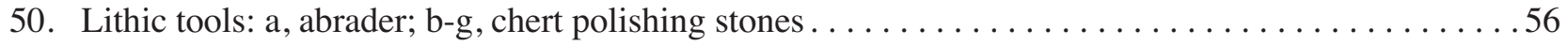

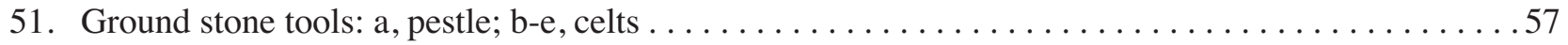

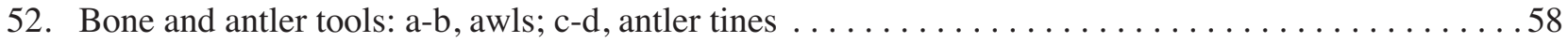

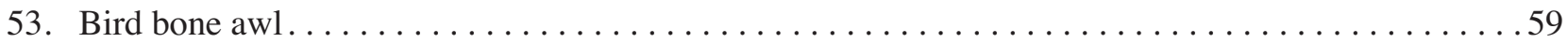


54. Other bone artifacts: a, deer cranium with attached antler stubs; $b$, drawing of perforated bear tooth; c, photograph of three bear teeth, 41BW2-22, courtesy of TARL . . . . . . . . . .59

55. Mussel and conch shell artifacts from the Eli Moores site: a, mussel shell hoe; b, apex of columella shell; c-d, Lampsilis sp. perforated shells; e, possible shell inlay . . . . . . . . . . . .60 60

56. Drawing of split cane basketry fragment from the Eli Moores site $\ldots \ldots \ldots \ldots \ldots \ldots \ldots \ldots \ldots$

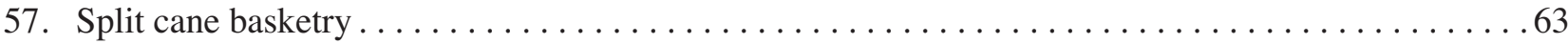

58. Summed probability distribution of calibrated radiocarbon dates from the Eli Moores site . . . . .75 


\section{List of Tables}

1. Rim and lip profiles for the plain ware, utility ware, and fine ware rim sherds in the Eli Moores ceramic assemblage. . . . . . . . . . . . . . . . . . . . . . . . . 26

2. Use of bone and shell temper in the ceramic wares at the Eli Moores site . . . . . . . . . 27

3. Decorative methods represented in the utility wares from the Eli Moores site . . . . . . . . . . 29

4. Incised decorative elements in the Eli Moores site utility wares................... 33

5. Trailed-Incised decorative elements in the Eli Moores site utility wares $\ldots \ldots \ldots \ldots \ldots \ldots \ldots$

6. Decorative methods represented in the fine wares from the Eli Moores site . . . . . . . . . . 39

7. Identified fine ware engraved ceramic types in the carinated bowls from the Eli Moores ceramic assemblage . . . . . . . . . . . . . . . . . . . . . . . . . 39

8. Indeterminate engraved rim and body sherds in the Eli Moores site fine wares $\ldots \ldots \ldots \ldots \ldots 4$

9. Plants from pecan deposit and midden at the Eli Moores site $\ldots \ldots \ldots \ldots \ldots \ldots \ldots \ldots \ldots \ldots \ldots \ldots \ldots \ldots \ldots \ldots$

10. Non-botanical items in the pecan deposit and midden from the Eli Moores site . ...........66

11. Corn cob fragments (complete diameters) from the Eli Moores site . . . . . . . . . . . . 67

12. Corn cupule dimensions from the Eli Moores site $\ldots \ldots \ldots \ldots \ldots \ldots \ldots \ldots \ldots \ldots \ldots \ldots \ldots \ldots \ldots \ldots \ldots \ldots$

13. Description of basketry fragments from the Eli Moores site $\ldots \ldots \ldots \ldots \ldots \ldots \ldots \ldots \ldots \ldots$

14. Inventory of plants from pecan deposit and midden at the Eli Moores site $\ldots \ldots \ldots \ldots \ldots \ldots$

15. Information on radiocarbon samples from the Eli Moores site $\ldots \ldots \ldots \ldots \ldots \ldots \ldots \ldots \ldots 74$

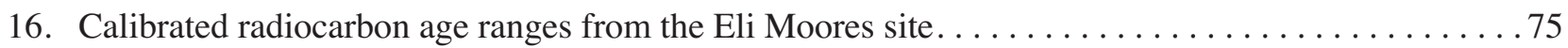




\section{Acknowledgments}

I would like to thank Laura Nightengale of the Texas Archeological Research Laboratory, The University of Texas at Austin (TARL), for all her help in accessing the Eli Moores site records and collections for study, and for her excellent photographs of ceramic vessels recovered at the site. Thanks also to Jean Hughes of TARL for scanning black and white photographs from the 1932 work at the site. Finally, thanks to Lance Trask for preparing many figures and maps for this publication. 


\section{Chapter 1, Introduction and Purpose of the Investigations}

The Eli Moores site (41BW2) is an important ancestral Caddo mound center and habitation site on the Red River in the East Texas Pineywoods, likely part of the Nasoni Caddo village visited by the Teran de los Rios entrada in 1691 (see Sabo 2012; Wedel 1978). The site may have been the residence of the caddi of the Nasoni Caddo when it was visited by the French and Spanish, and the Xinesi lived in a temple on the mound at the nearby Hatchel site. The site was investigated by the University of Texas in 1932 (Jackson 1932; Good 1977; Gilmore 1991), and in one of the mounds and in associated midden deposits, the remains of Caddo structures, midden deposits, features, eight burials (with nine individuals), and a large ceramic and lithic assemblage were recovered, along with well-preserved plant and faunal remains.

Unfortunately, however, the results of these excavations and the recovered artifact assemblage received only the most cursory investigation and analysis (e.g., Jackson 1932). As a result the significance of the site with respect to how it can contribute to a better understanding of the regional Caddo archaeological record for the 17th and early 18th century as well as a better appreciation of the nature of early contacts between Nasoni Caddo peoples and French and Spanish explorers and traders has not been realized. This monograph remedies this situation by completing a reanalysis of the existing 1932 excavation and feature records as well as the recovered artifact assemblage and plant remains that are curated at the Texas Archeological Research Laboratory at The University of Texas at Austin (TARL) and presents in detail the significant archaeological findings of the 1932 excavations. This reanalysis was initiated in the Fall of 2013.

AS discussed below, the artifact analysis focuses on the detailed stylistic and technological analysis of the plain and decorated sherds; vessels and vessel sections; clay pipes; chipped and ground stone tools; and bone and shell tools and ornaments in the Eli Moores assemblage. Drawings and/or photographs have been taken of representative artifacts from the different artifact classes, and photographs taken of the vessels and vessel sections, along with drawings of their decorative motifs and elements. The artifact analysis also includes descriptions of the small assemblage of European glass beads and lead balls (from burial J-3) in the Eli Moores collection.

\section{Setting}

The Eli Moores site is situated on a natural levee of the Red River, currently about $2.5 \mathrm{~km}$ north of the site (Figure 1). There are oxbow lakes and back swamp areas to the immediate north and south of the site, including the recent cutoff called Clear Lake. The natural levee soils are a very fine sandy loam ranging from a red to a grayish-red color, principally used in modern times for crops.

Before the land was cleared beginning in the early 19th century, this section of the Pineywoods would have had a variety of native plant communities, including cypress-tupelo swamp, bottomland prairies, bottomland/floodplain hardwood forests, upland hardwood-pine forests and upland hardwood forests, canebrakes, and cedar forests (MacRoberts and MacRoberts 2008). In the early 1800s along the Red River north of Shreveport, Louisiana, cedar "grew as a forest on both sides of the river for a distance of many miles" (MacRoberts and MacRoberts 2008:22).

\section{Cultural Context}

The principal occupation of this part of the Red River basin in East Texas in prehistoric and early historic times (up to about A.D. 1790) was by Caddo-speaking Indian groups that lived in settled horticultural and agricultural communities (cf. Barr 2007, 2011; Campbell 1996; Foster 2008). In historic times, 


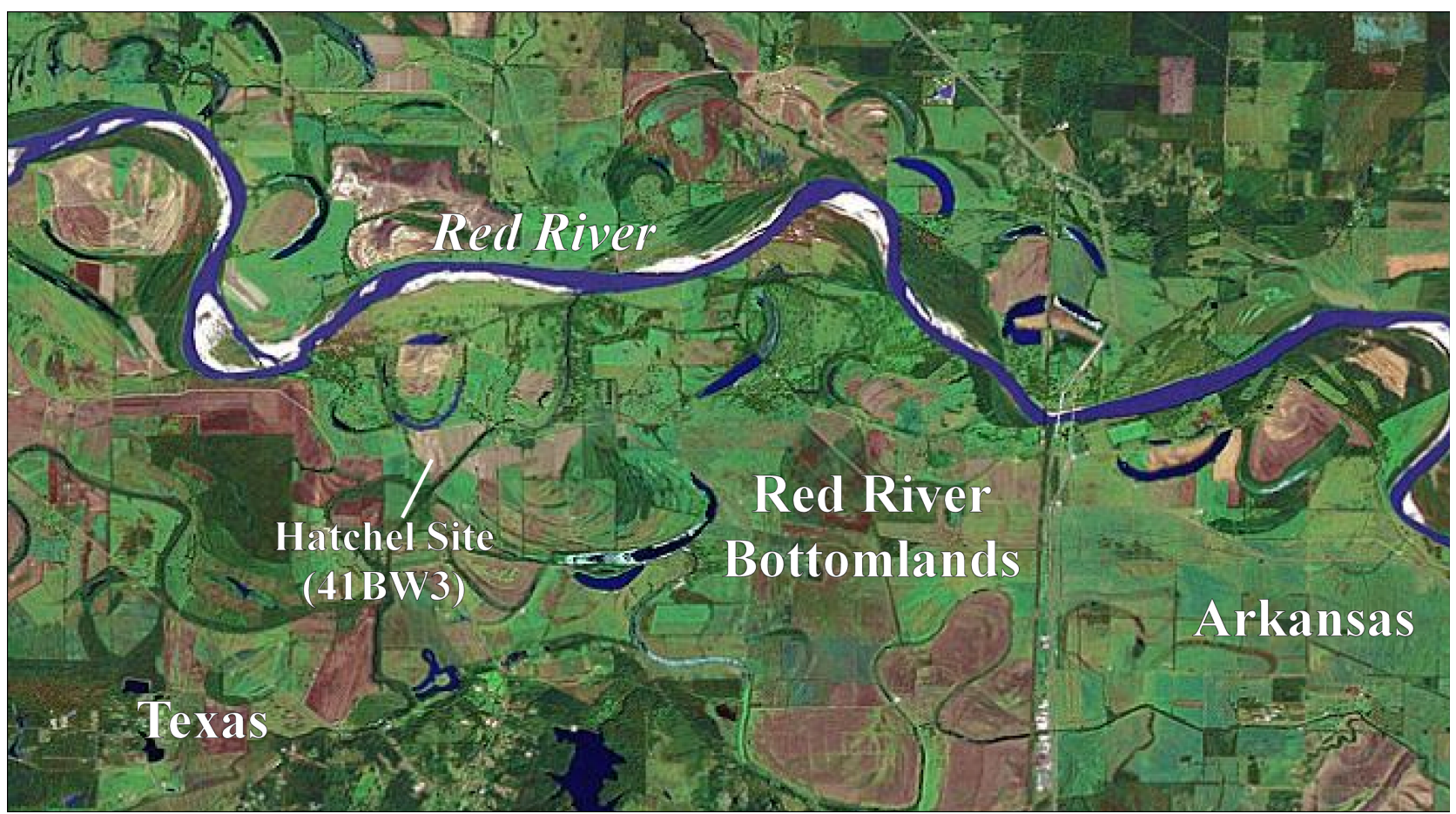

Figure 1. Aerial photograph of the Red River alluvial bottomlands in the area of the Eli Moores (41BW2) and Hatchel (41BW3) sites.

there were several Caddo "confederacies" in East Texas and Northwest Louisiana, including the Kadohadacho on the Red River and the Hasinai in East Texas (Figure 2).

These Kadohadacho communities were composed principally of farmsteads and small hamlets, but larger villages, as at the Hatchel, Mitchell, Eli Moores (41BW2), Hill Farm (41BW169), and Cabe (41BW14) sites (Figure 3) occupied by the Nasoni Caddo, were situated along the Red River bottomlands during much of the prehistoric and historic era (e.g., Story 1990; Creel 1996; Perttula 2005; Perttula et al. 1995; Sundermeyer et al. 2008), particularly during the Texarkana phase, the latest Caddo culture in the area (Creel 1996:505). Caddo archaeological sites in the region are known to be primarily located on elevated landforms (alluvial terraces and rises, natural levees, and upland edges) adjacent to the major streams, as well as along spring-fed branches and smaller tributaries with dependable water flow. They are also located in proximity to arable sandy loam soils, presumably for cultivation purposes with digging sticks and stone celts.

These Caddo groups were powerful theocratic chiefdoms that built earthen mounds (like the platform mound at the Hatchel site, see Jackson 2004) for political and religious purposes, functions, and rituals, traded extensively across the region as well as with non-Caddoan speaking groups, and developed intensive maize-producing economies by the 13th century A.D. Due to diseases introduced by Europeans sometime after the mid-16th century, and the incursions of the Osage to obtain deer hides and Caddo slaves, by about 1790, the Red River valley in the Texarkana area was abandoned by the Caddo groups.

In late November to early December 1691, a Spanish expedition led by Don Domingo Teran de los Rios explored the Red River area and a Nasoni Caddo village (Hatcher 1932, 1999). As the expedition came to the village, they noted a hill "which commanded the whole country." The hill turned out to be 


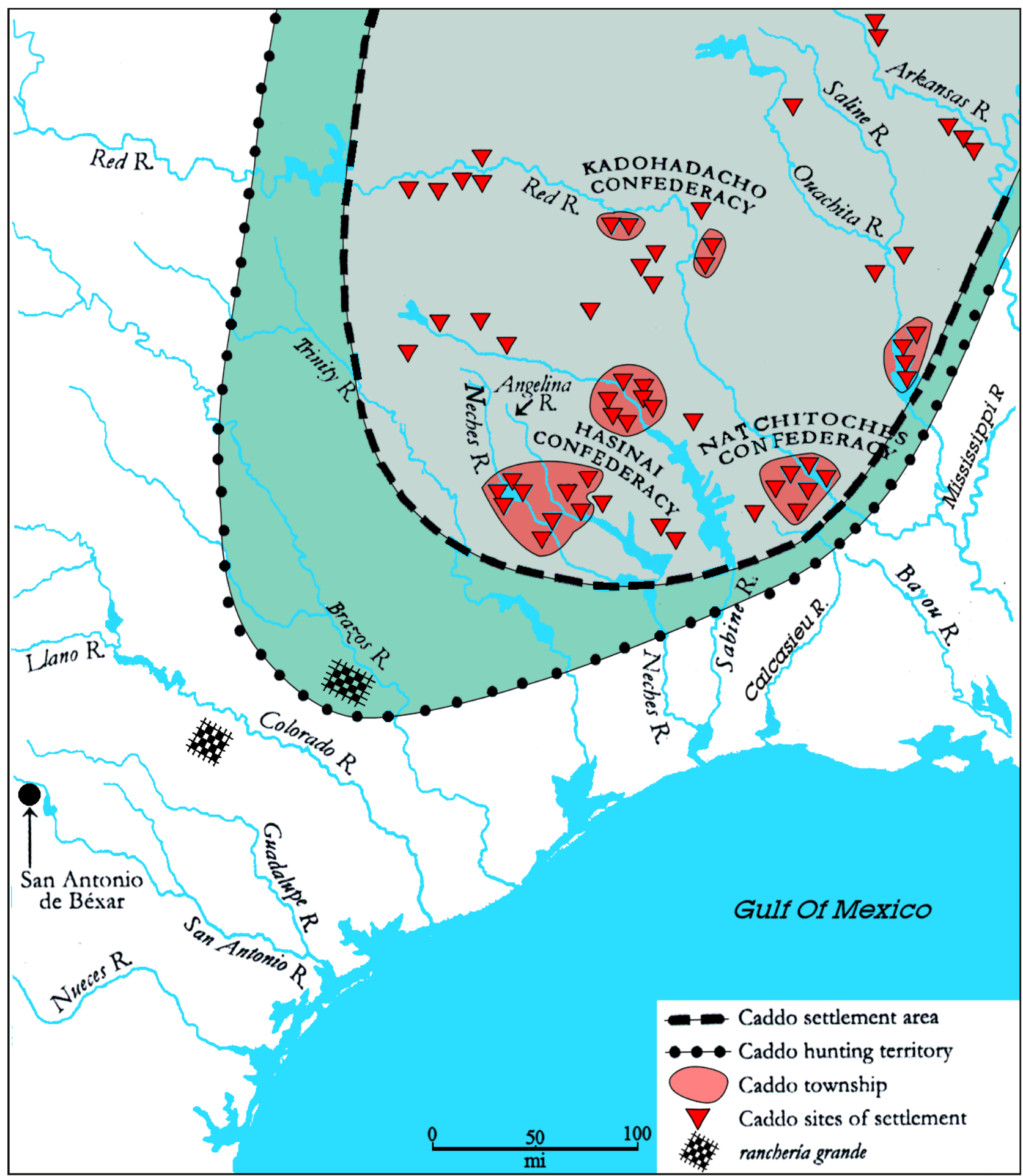

Figure 2. Caddo settlement areas in the southern Caddo area at ca.A.D. 1690 (after Barr 2011:Figure IV).

"the temple in which the Indians worshipped and made offerings to their gods" (Hatcher 1999:33). From the temple mound, the expedition "made camp at the home of an Indian whom they called Caddi, located about half a league, more or less from the temple or mesguita" (Hatcher 1999:33); Teran named the place Santa Galia. The caddi was a young man between 12-14 years of age. The caddi's compound was thus about 1.3 miles from the temple mound; at that time a league was a standard measurement of distance, 


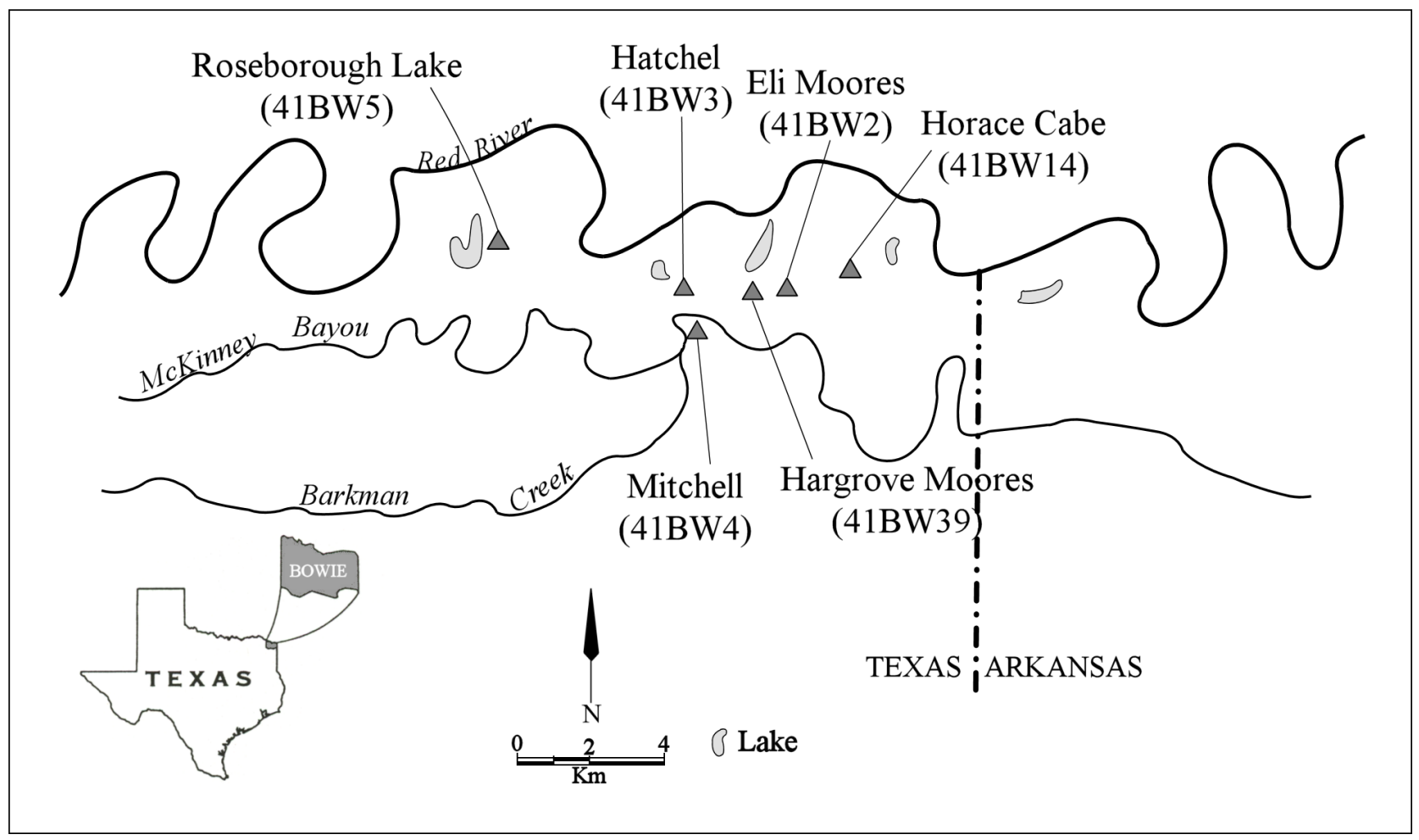

Figure 3. Important Caddo archaeological sites along the Red River in the vicinity of the Eli Moores site.

being approximately 2.6 miles (Foster 1995:9). The distance between the temple mound and the caddi's compound (Figure 4) matches the overland distance between the platform mound at the Hatchel site and the mounds and settlement at the Eli Moores site.

Teran noted that there were Caddo settlements on both banks of the river, and that "the settlements extended down stream along the river bank" (Hatcher 1999:35). Teran also noted:

the respect showed the caddi by the Indians. They offered him a seat as soon as they saw him, a deference they did not show in the case of the others who accompanied us. I noticed, too, that they had a captain, but that he is under the orders of the caddi, the latter being the arbiter and ruler of the entire nation (Hatcher 1999:35).

During that time a detailed map was drawn of a Nasoni Caddo village that depicted a templo or temple mound at the western end of the village, and a compound near the center of the village (see Figure 4), marked by a cross and the word Cadi, indicating that this was the compound of the village's political leader, the caddi. The caddi's compound had two structures, one larger than the other; the larger structure was the caddi's residence, while the other may have "housed the community officials' assistants" (Sabo 2012:436). There are two upright posts in front of (to the south) the caddi's dwelling, as well as a Christian cross behind and to the east of the dwelling. There were no elevated storage facilities shown in the caddi's compound, only one open platform or ramada, and a rectangular gable-roofed structure that Sabo (2012:436) suggests may have been a shelter erected by Teran's men. Finally, the Teran map shows a slight rise in the land south of the caddi's residence and the two upright posts, and this rise may mark the larger of the two mounds at the Eli Moores site. 


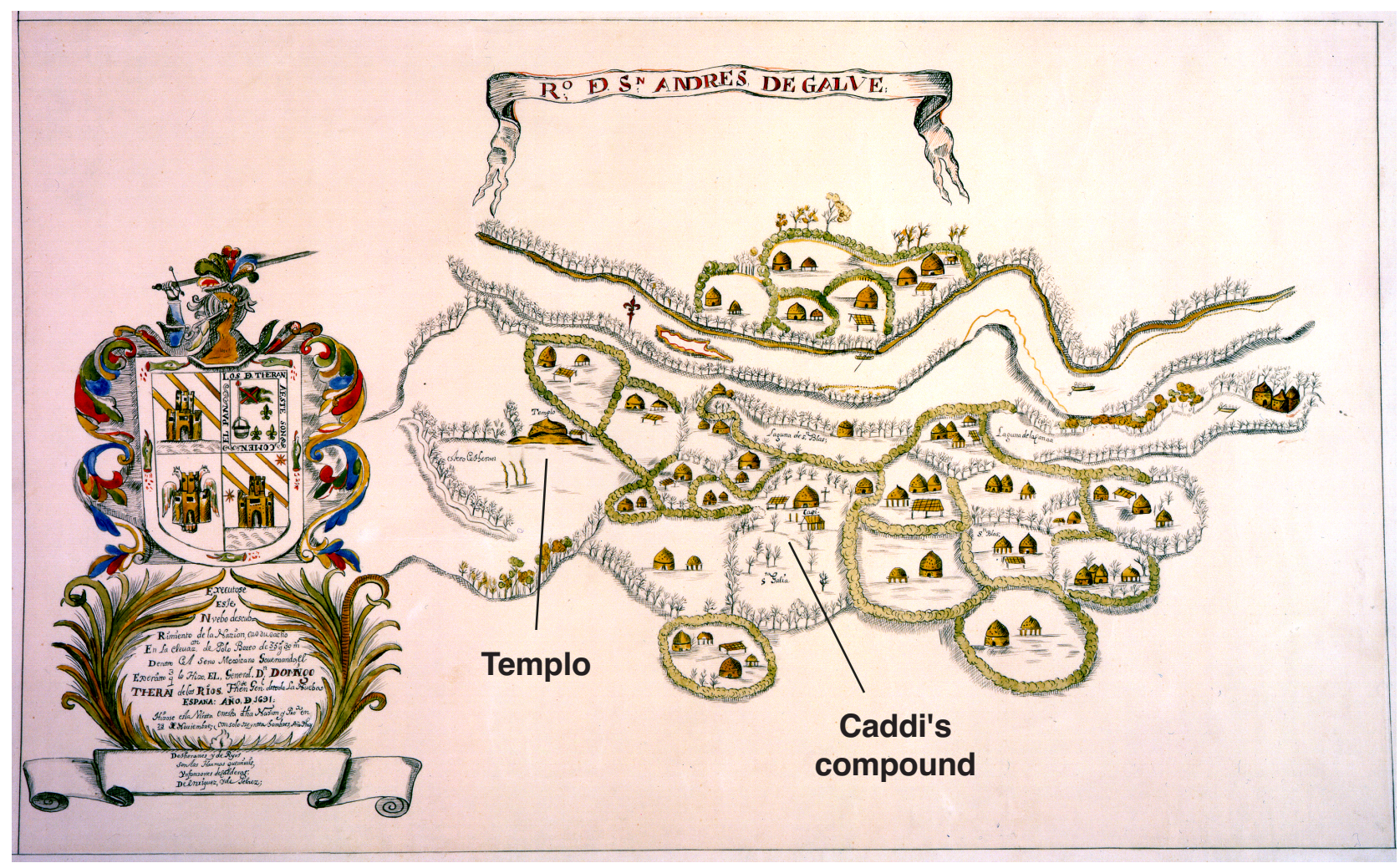

Figure 4. The 1691 Teran map. Original in the J.P. Bryan Map Collection, CT0108, Center for American History at the University of Texas at Austin.

In addition, the Teran map shows 25 building clusters or compounds, "probably individual farmsteads with one or two dwellings, elevated storage platforms, and open platforms or ramadas" (see Figure 4). The dwellings are shown with cylindrical walls and clearly distinguishable "beehive" roofs that appear to be thatched." The elevated storage platforms are also covered with thatched "beehive" roofs. The open platforms appear to have mat, brush, or bark coverings" (Sabo 2012:435).

The large mound on the map has been identified as the large earthen mound at the Hatchel site (see Wedel 1978), while the caddi's compound may well have been at the Eli Moores site. As noted above, the map also showed many houses, and associated outbuildings, from numerous individual compounds in the village. The village itself is believed to have extended several miles along the Red River, likely encompassing contemporaneous sites such as Eli Moores (41BW2), Paul Mitchell (41BW4), Hargrove Moores (41BW39), Hill Farm (41BW169), and Horace Cabe (41BW14) (see Figure 3).

In Fray Massanet's diary of the Teran expedition, he noted that there were "white men" living with the Kadohadacho. These were Frenchmen from La Salle's doomed expedition (Foster 1998). The French had given the Kadohadacho "many glass beads, jingles and other things not previously known to the Indians" (Hatcher 1999:62).

Wedel (1978:15) has suggested that La Harpe's 1719 trading post was built in the caddi's compound at the Eli Moores site. She notes that "this village, east of the temple mound [at the Hatchel site] was probably the main concentration of Upper Nasoni from 1687 to 1720, as well as in prehistoric times" (Wedel 1978:14). The French trading post was only in operation at the Upper Nasoni village for about six months. 


\section{Background to the 1932 Excavations}

According to A. T. Jackson (1932:1) the Eli Moores site first came to the attention of the landowner in 1902 when a Red River flood washed out a number of Caddo pottery vessels; this was more than 650 m northeast of the two mounds at the site (Good 1977) (Figure 5). In 1931, human remains and ceramic sherds were also washed out and exposed along a drainage ditch about $100 \mathrm{~m}$ west of the 1902 find spot. UT investigated the 1902 and 1931 localities in 1932, but no further burials or vessels were found there (Jackson 1932:6, 51).

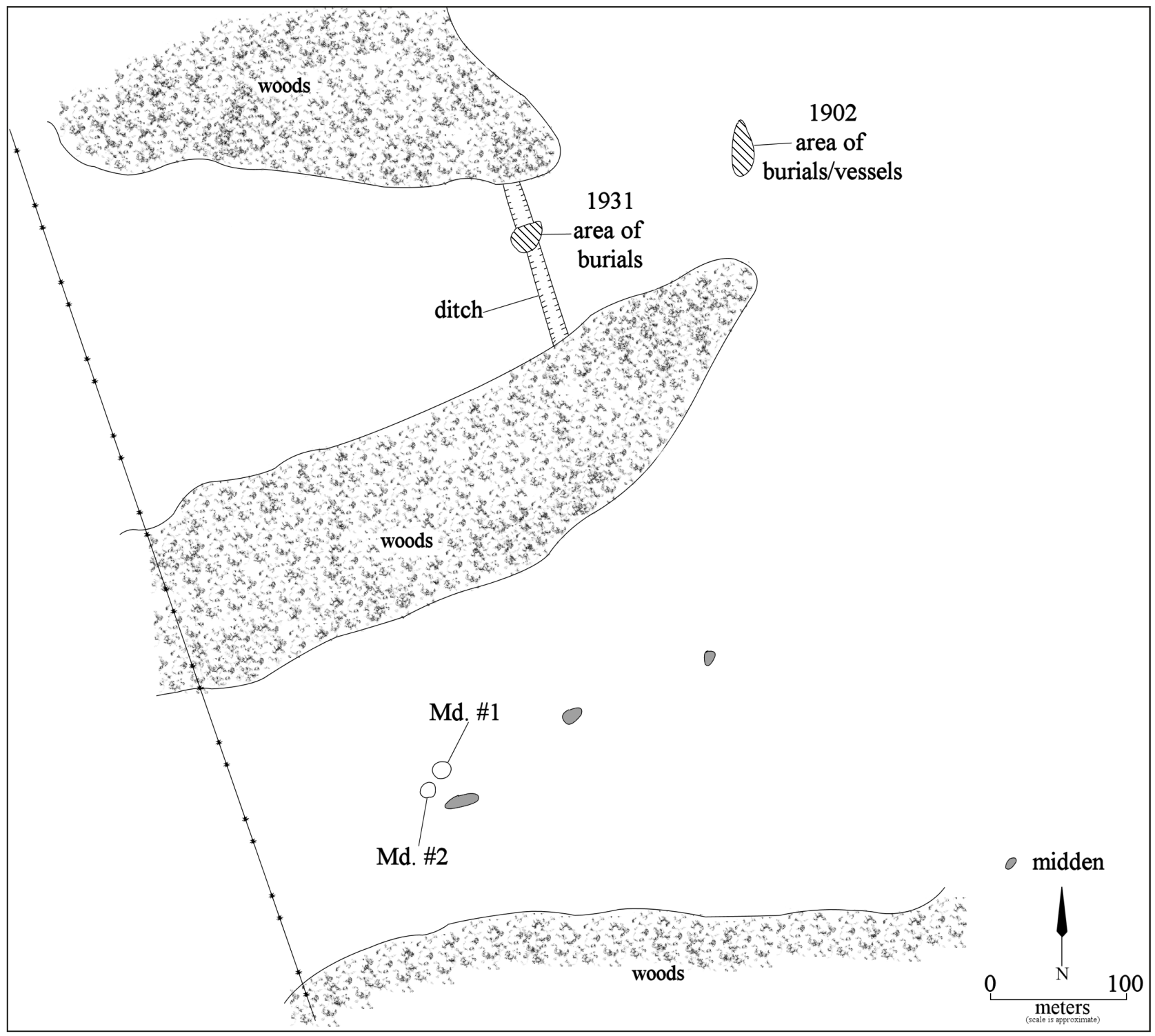

Figure 5. The mounds at the Eli Moores site, along with midden areas and 1902 and 1931 areas of burials and ceramic vessels. 
C. B. Moore (192:637) visited the Eli Moores site in March 1912, and noted "two mounds of moderate size, on one of which were two buildings." Moore also commented that the "other mound had been very largely dug into. Although the owner of the property, Mr. E. H. Moores, who resides upon it, was willing to permit investigation, it was decided not to attempt it under the circumstances."

Since neither of the two mounds at the Eli Moores site had buildings on them at the time of the 1932 UT excavations, it is unclear which mound C. B. Moore was referring to, although it is likely Mound \#1 (see Figure 5). Nor is it clear which of the two mounds had apparently already been dug into, but it is suspected that it was Mound \#2 (Good 1977), which was nearby, and had a hole dug into its west side (Jackson 1932:1, 55). 


\section{Chapter 2, 1932 Excavations}

The University of Texas 1932 excavations, between August 12-September 2, at the Eli Moores site concentrated on Mound \#1. This mound was estimated to be ca. $20 \mathrm{~m}$ in diameter and $1.5 \mathrm{~m}$ in height, and there was a borrow pit directly north of the mound (Figure 6). A blue glass bead had been previously found on the surface of the mound (TARL 1931:28). Mound \#2 is ca. 12 m southwest of Mound \#1, while an unexplored mounded midden deposit is ca. $15 \mathrm{~m}$ south of Mound \#1. Mound \#2 had a small "test hole" excavated in it by the UT crew, but only midden deposits were encountered there (Jackson 1932:51); a small borrow pit was located just south of this mound. Jackson also noted that there were several midden deposits north and east of Mound \#1, one of which had much daub (Jackson 1932:55), suggesting it was the location of a burned structure.

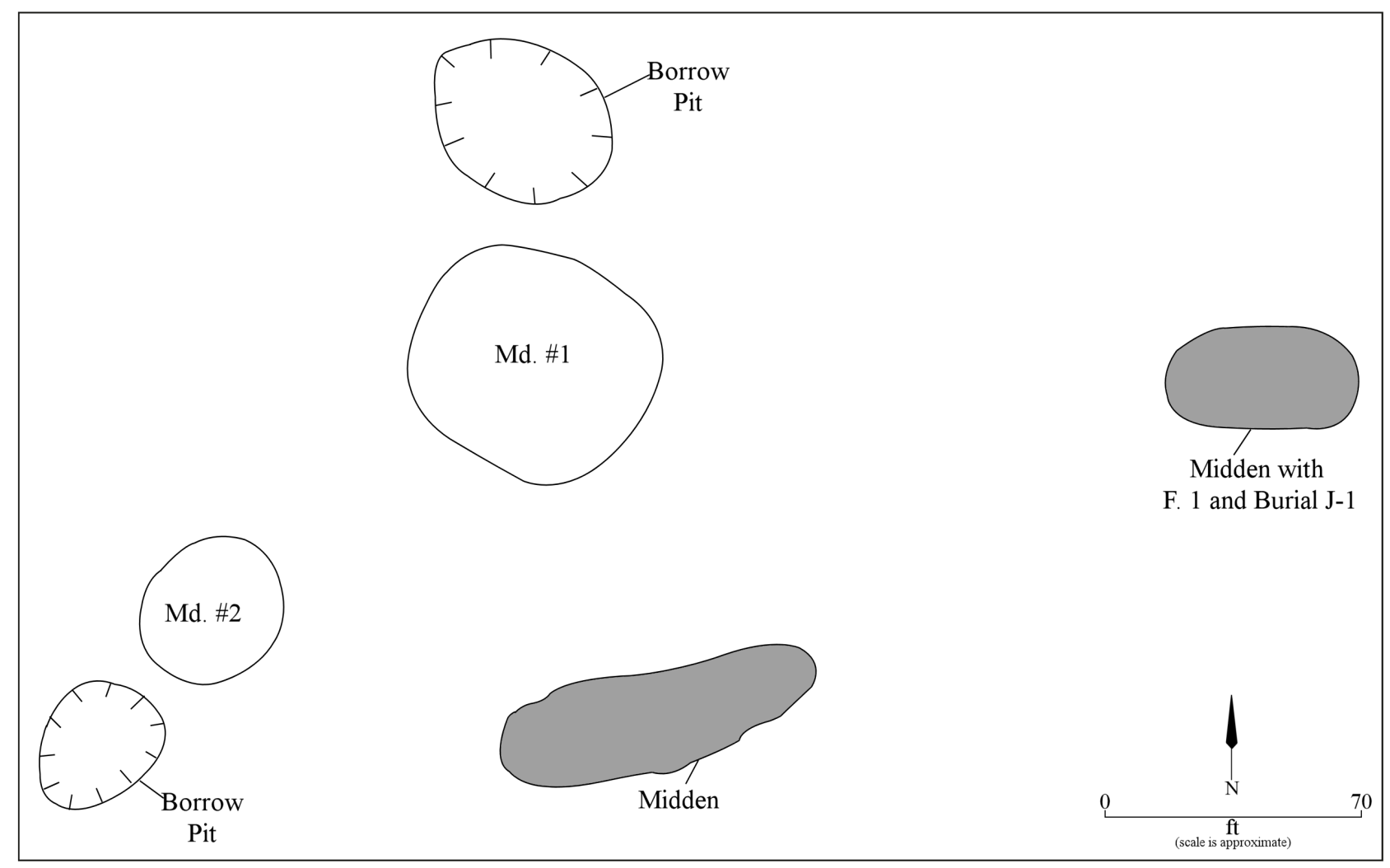

Figure 6. Plan of mounds, borrow pits, and one midden area at the Eli Moores site.

In one of these midden deposits (about 45 m east of Mound 1, see Figure 6) a Caddo burial (J-1) and a flexed dog burial (Feature 1) were discovered lying about $1.8 \mathrm{~m}$ apart in the excavations (Jackson 1932:7-8); the small to medium-sized adult dog (Good 1977) may have been associated with the Caddo burial as it lay near the feet of the deceased Caddo adult. The Caddo burial was that of a 20-30 year old female (Lee 1997:Table 2, Accession 577), with her head to the southeast. The Caddo burial was found only ca. $15 \mathrm{~cm}$ bs, and had been disturbed by plowing; skull fragments were noted on the surface before the excavations began. Associated with the individual were two ceramic vessels (a bowl and a jar) and a ceramic spindle whorl. The dog lay slightly deeper $(\mathrm{ca} .30 \mathrm{~cm} \mathrm{bs}$ ); fragments of one of the vessels were found above the dog's head.

The excavations in Mound \#1 proceeded first through the excavation of $1.5 \mathrm{~m}$ wide north-south and east-west trenches that cut across much of the mound, and then much of the central portion of the mound 
was excavated (Figure 7). These excavations encountered evidence of two wood structures (that may have been burned down), an ash pit, and seven burials (J-2 to J-8).

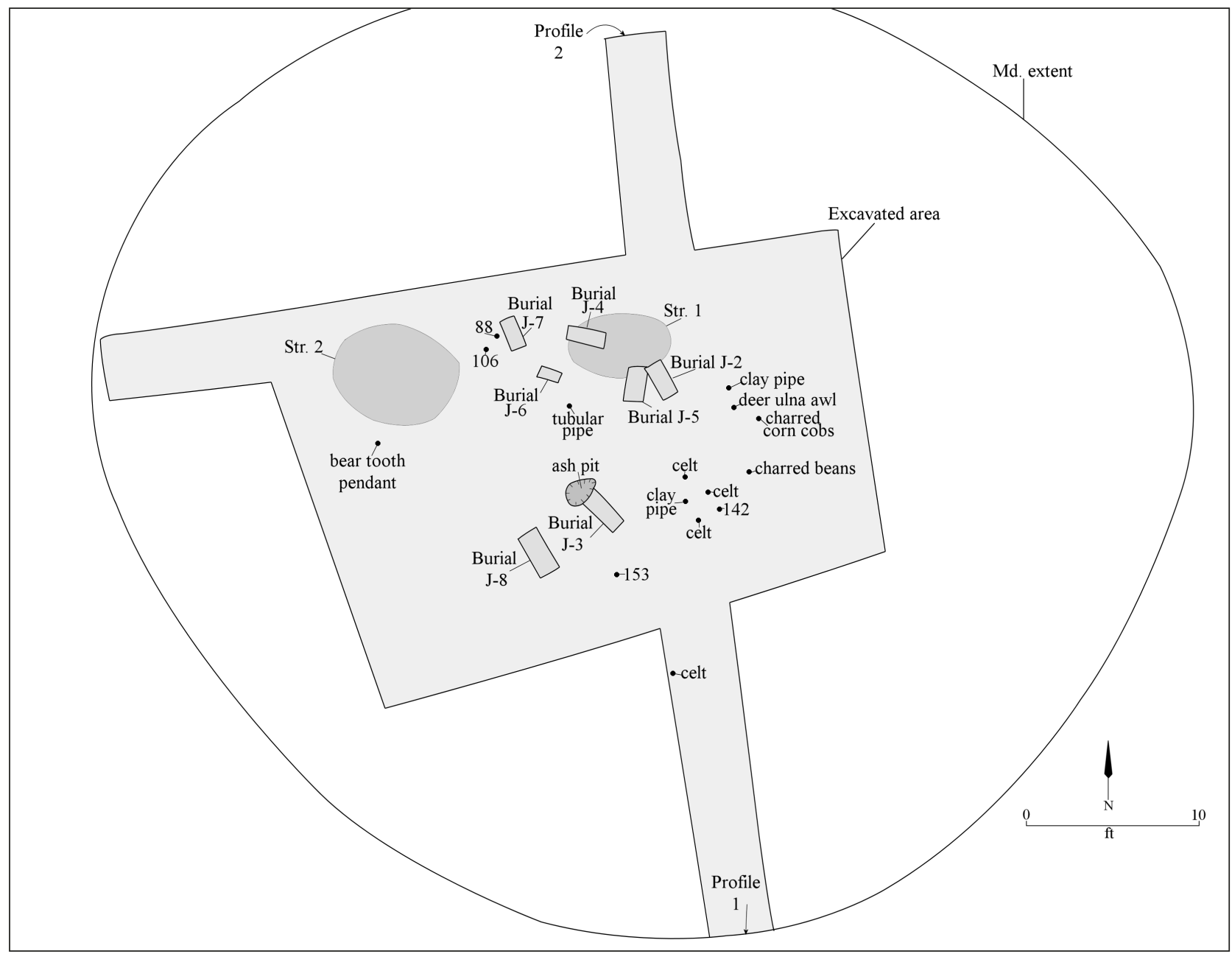

Figure 7. Jackson's plan map of excavated areas in Mound \#1 at the Eli Moores site, and locations of burials, structures 1-2, and various artifact find spots.

Profiles on the north and south sides of the north-south trench bisecting Mound \#1 indicates that the mound deposits were comprised of stratified midden deposits and a clay zone, the latter perhaps indicative of either structural zones or clay caps in the mound fill (Jackson 1932:9-10). In Profile 1 at the south end of the mound, the profile was:

- $\quad 0-10 \mathrm{~cm}$ bs, a red sandy loam, plowed

- $\quad 10-25 \mathrm{~cm}$ bs, a midden deposit, intermixed with red clay

- $\quad 25-46 \mathrm{~cm}$ bs, a red soil [clay?] with few artifacts

- 46-104 cm bs, a midden deposit, intermixed with red clay, and

- $104 \mathrm{~cm}$ bs+, undisturbed red sand, likely the original A-horizon of the local Miller very fine sandy loam soil. 
In Profile 2, at the north end of the mound, the profile was described as:

- $\quad 0-13 \mathrm{~cm}$, red sandy loam, plowed

- $\quad 13-43 \mathrm{~cm}$, red clay with very few artifacts

- 43-125 cm bs, a midden deposit, intermixed with red clay, and

- $125 \mathrm{~cm}$ bs+, undisturbed red sand, likely the original A-horizon.

The 3rd profile was more complex in the central part of the north-south trench, with evidence of two structural zones marked by red clay mound fill zones:

- $\quad 0-10 \mathrm{~cm}$ bs, red sandy loam, plowed

- $10-33 \mathrm{~cm}$ bs, red clay, with very few artifacts

- $\quad 33-61 \mathrm{~cm}$, midden deposits with ashes and burned clay/daub and much charcoal

- 61-125 cm, midden deposits with considerable ash and some burned clay

- $\quad 125-155 \mathrm{~cm}$, red clay, with some charcoal but no ash and few artifacts

- $155 \mathrm{~cm}$ bs+, undisturbed red sand, likely the original A-horizon.

This profile suggests that the mound fill comprised of midden deposits also contains evidence for the burning of structures as well as much wood, producing a $92 \mathrm{~cm}$ thick deposit with quantities of ash, burned clay, and charcoal. The red clay zones were used to first create a mound platform $(125-155 \mathrm{~cm} \mathrm{bs})$ and then also as a mound fill capping event $(10-33 \mathrm{~cm} \mathrm{bs})$. In the south mound profile, the mound was again occupied after the clay capping event.

\section{Structure \#1 (Feature 4)}

This structure is represented by four post holes outlining a ca. 1.8 × $2.7 \mathrm{~m}$ rectangular area, possibly some form of structural platform, in the central part of the mound. Burial J-4 lies within the structure, and Burial J-2 lies just outside it (Figure 8). The post holes were exposed between $69-76 \mathrm{~cm}$ bs (Jackson 1932:27). The one preserved piece of cane matting (see below) and the pecan nutshell cache (Feature 3) may have been associated with this feature (Good 1977) (Figure 9).

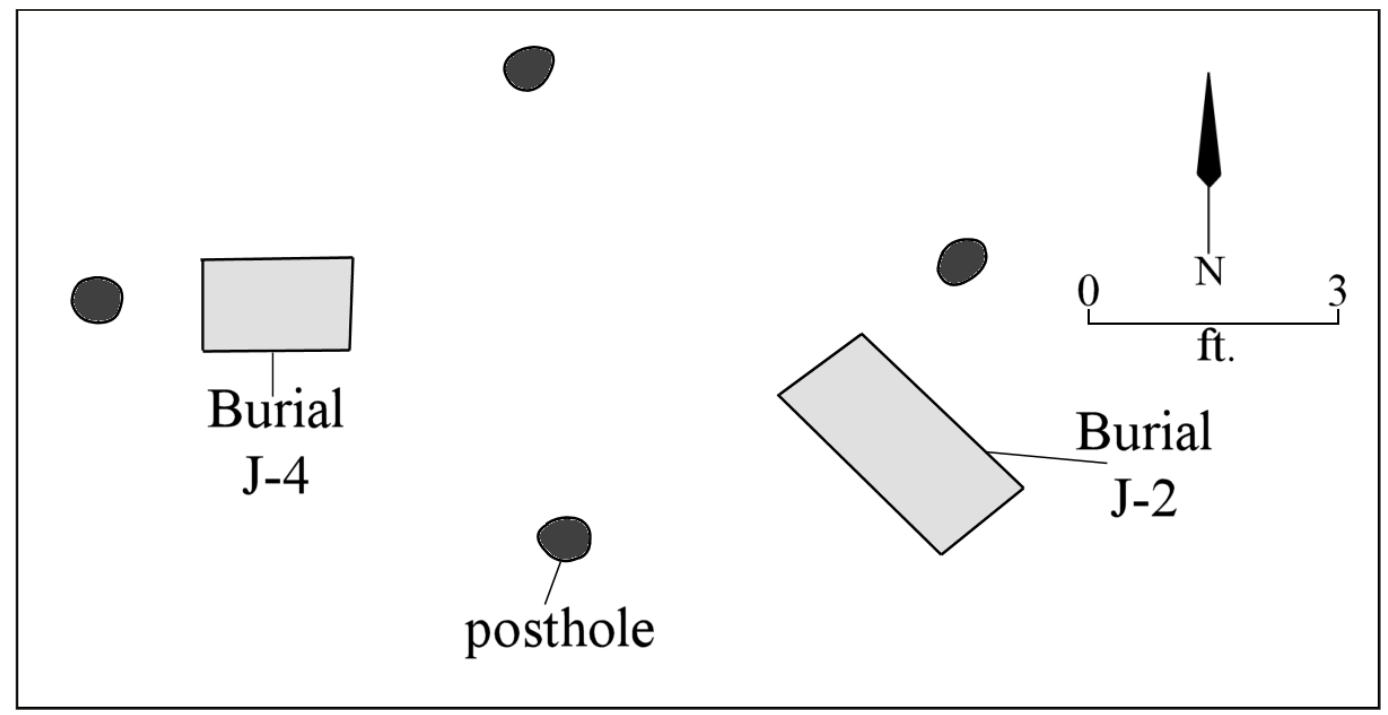

Figure 8. Plan of post holes associated with Structure \#1, and locations of Burials J-2 and $\mathrm{J}-4$. 


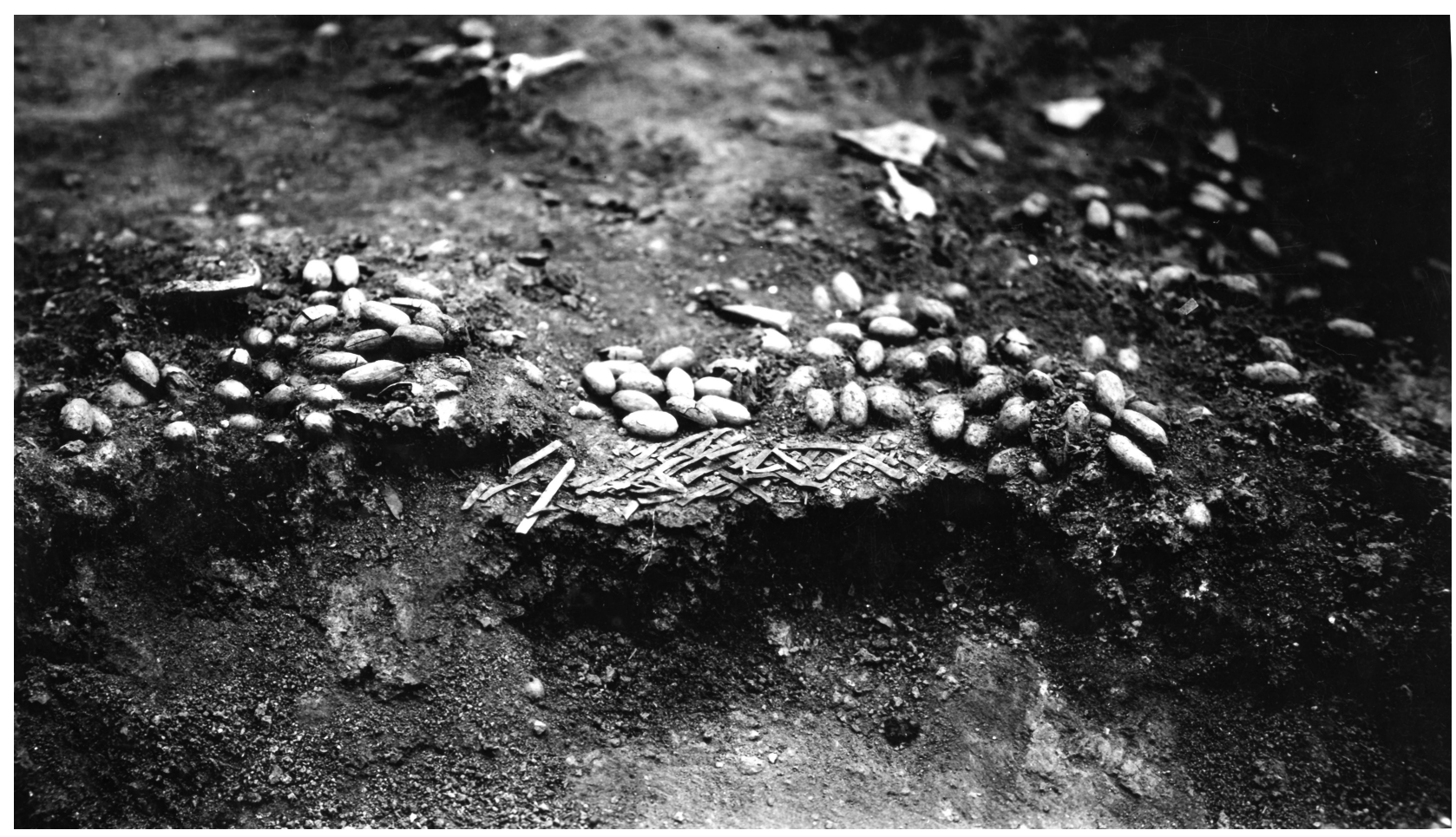

Figure 9. Close-up of the cane matting and pecan nutshell cache in Structure \#1 at the Eli Moores site. Photograph courtesy of TARL.

\section{Structure \#2 (Feature 5)}

Structure 2 in the western part of Mound \#1 (see Figure 7) was marked by an oval-shaped area of 11 post holes about ca. $2.5 \times 3.6 \mathrm{~m}$ in size (Jackson 1932:42) (Figures 10 and 11). The post holes were exposed at a depth between $56-66 \mathrm{~cm}$ bs. It seems likely that only a portion of this structure, perhaps part of two walls of a rectangular-shaped feature, or two structures (see Good 1977), was actually exposed in the 1932 UT excavations.

\section{Ash Pit (Feature 2)}

The $97 \times 127 \mathrm{~cm}$ ash pit was near the center of the mound (see Figure 7), from ca. 20-45 cm bs, in the upper midden mound fill deposit. It was excavated over the foot of Burial J-3, and penetrated into the foot area of the grave (Jackson 1932:23).

\section{Burials in the Mound}

Seven burials were excavated in Mound \#1 at the Eli Moores site, including eight individuals. Six of the burials (and seven individuals) are children less than 6-7 years of age at their death, while Burial J-3 is that of an adult male; Good (1977) considers this burial to be intrusive into the mound, while the others were buried during the accumulation of the mound midden deposits.

\section{J-2 (Accession No. 573)}

This is the burial of a child of unknown age (see Lee 1997:Table 2), possibly 8-9 years of age (Good 1977), laid in the grave (at a depth of $91 \mathrm{~cm} \mathrm{bs)} \mathrm{in} \mathrm{an} \mathrm{extended} \mathrm{supine} \mathrm{position} \mathrm{with} \mathrm{its} \mathrm{head} \mathrm{facing} \mathrm{to}$ 


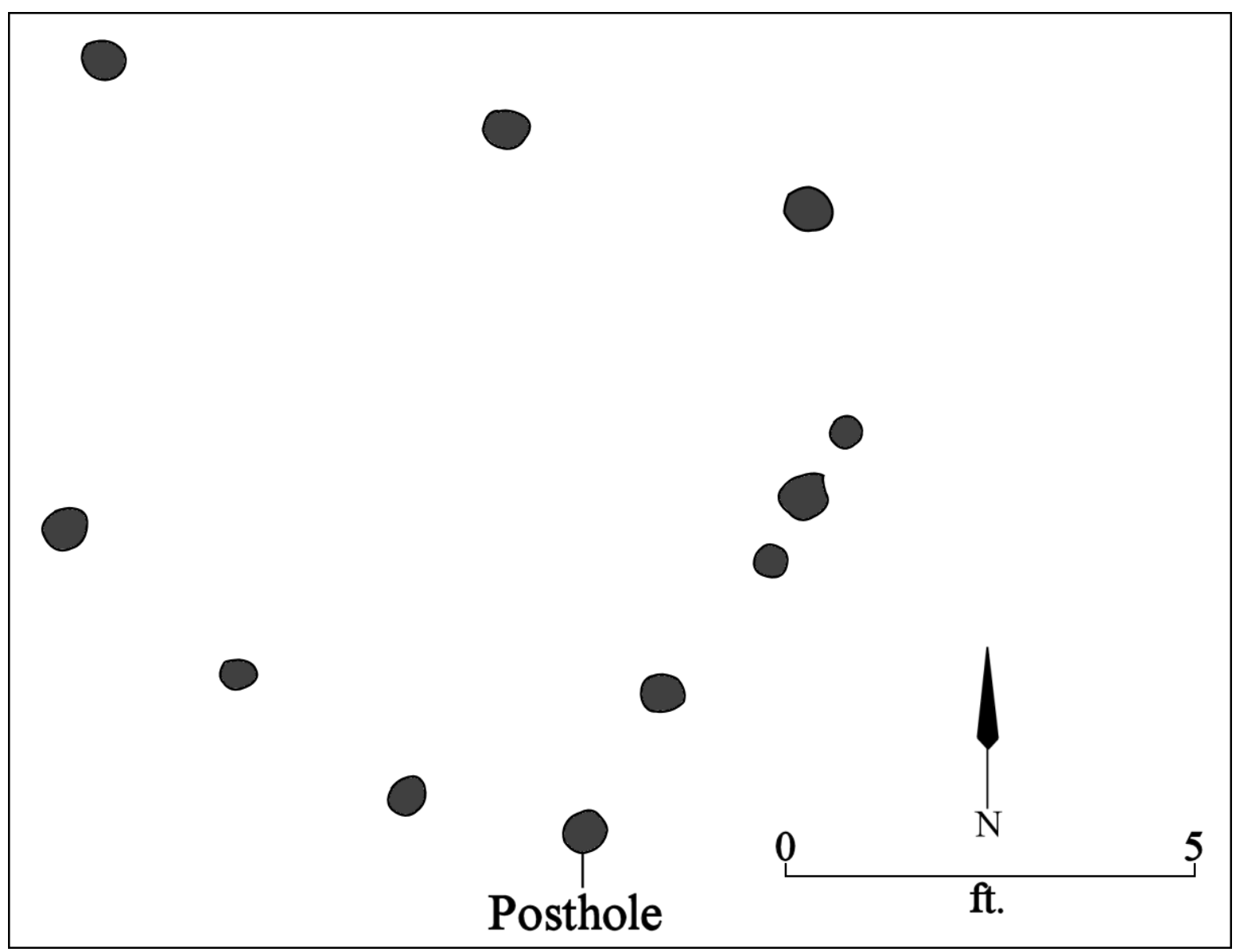

Figure 10. Post hole plan of Structure \#2 at the Eli Moores site.

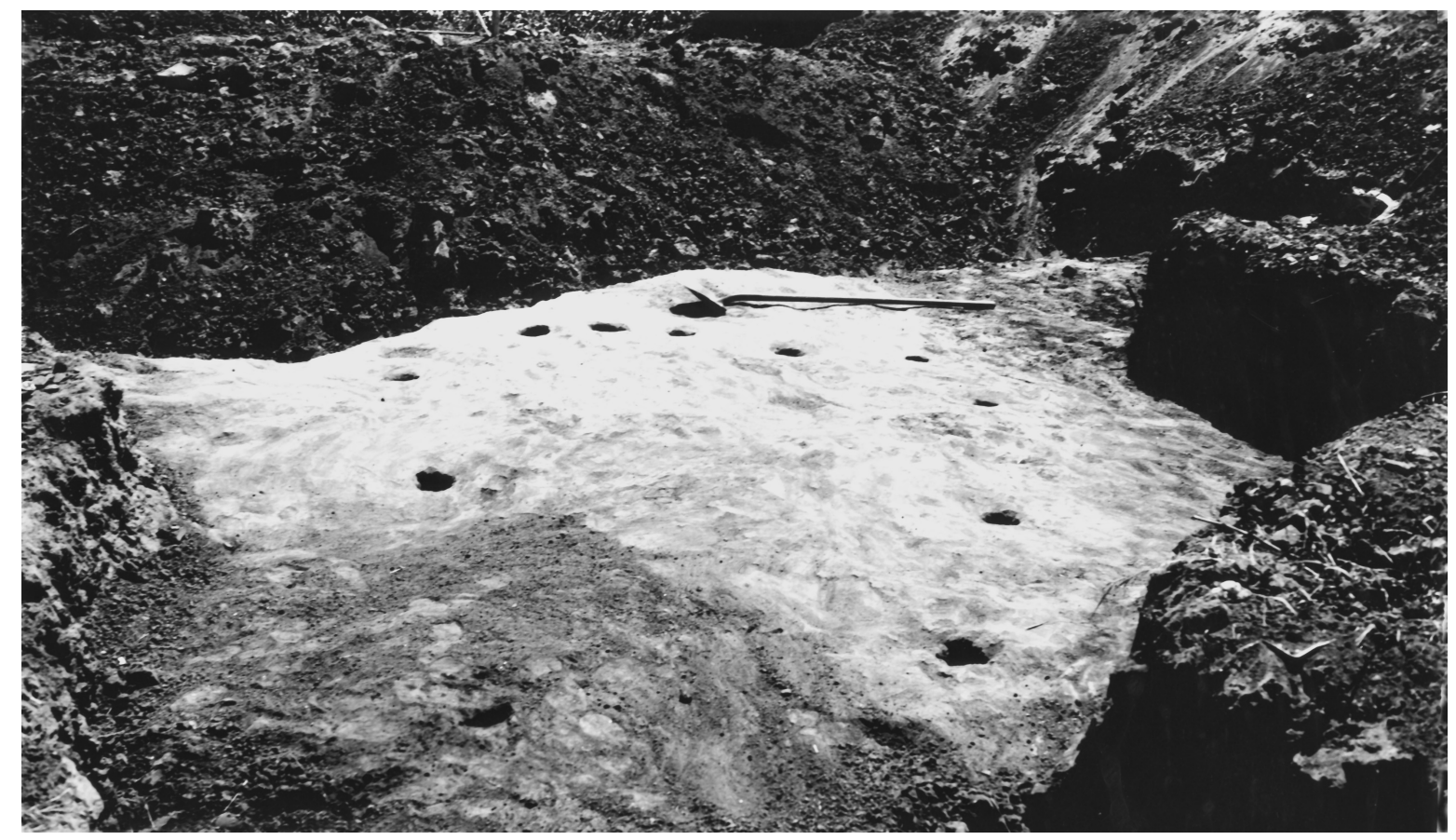

Figure 11. Structure \#2 at the Eli Moores site. Photograph courtesy of TARL. 
the southeast (Figure 12). There were two ceramic vessels - an incised-punctated jar (cf. Pease BrushedIncised, Artifact 63), a broken bowl, and a Simms Engraved carinated bowl (Artifact 33) - placed in the grave as grave goods, along with a Maud arrow point and a $152.4 \mathrm{~mm}$ long Ouachita Mountains greenstone celt (Figure 13) placed above its head; the celt has a $36.0 \mathrm{~mm}$ bit width and a $33.0 \mathrm{~cm}$ bit height. There was also a section of a grog-tempered Taylor Engraved carinated bowl (Artifact 64) in the Burial $\mathrm{J}$-2 fill; this vessel section is decorated with stacked engraved scroll elements with hooked arm endings (Figure 14). The burial fill had charcoal and ash, and there were a number of charred pecan nuts and one charred bean near the chin of the deceased (Good 1977).

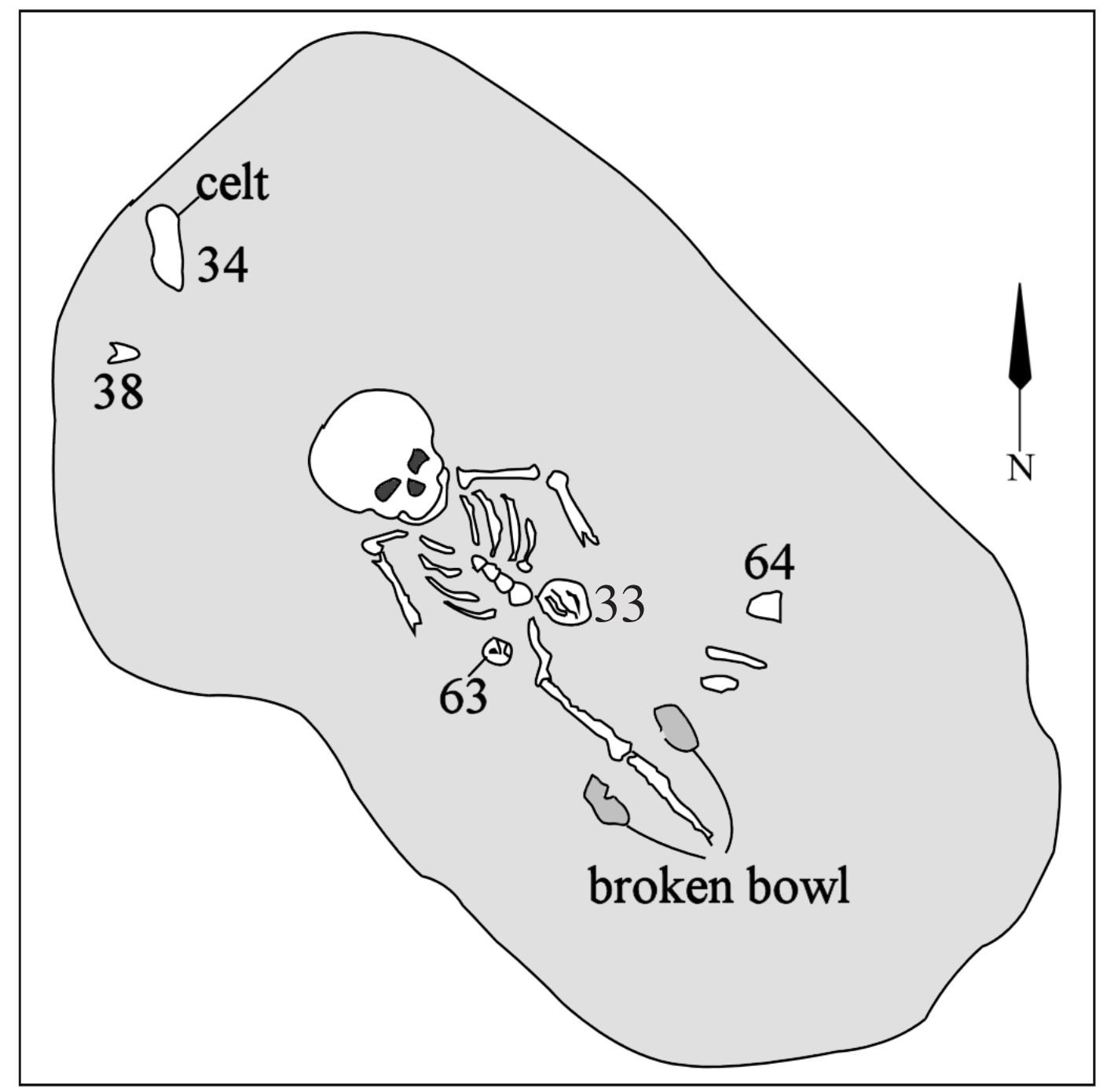

Figure 12. Plan of Burial J-2 at the Eli Moores site.

Sherds in the fill of this burial include a plain shell-tempered body sherd and two plain body sherds from a grog-tempered carinated bowl. There is also a grog-tempered Foster Trailed-Incised body sherd with multiple parallel to curvilinear incised and trailed lines. 


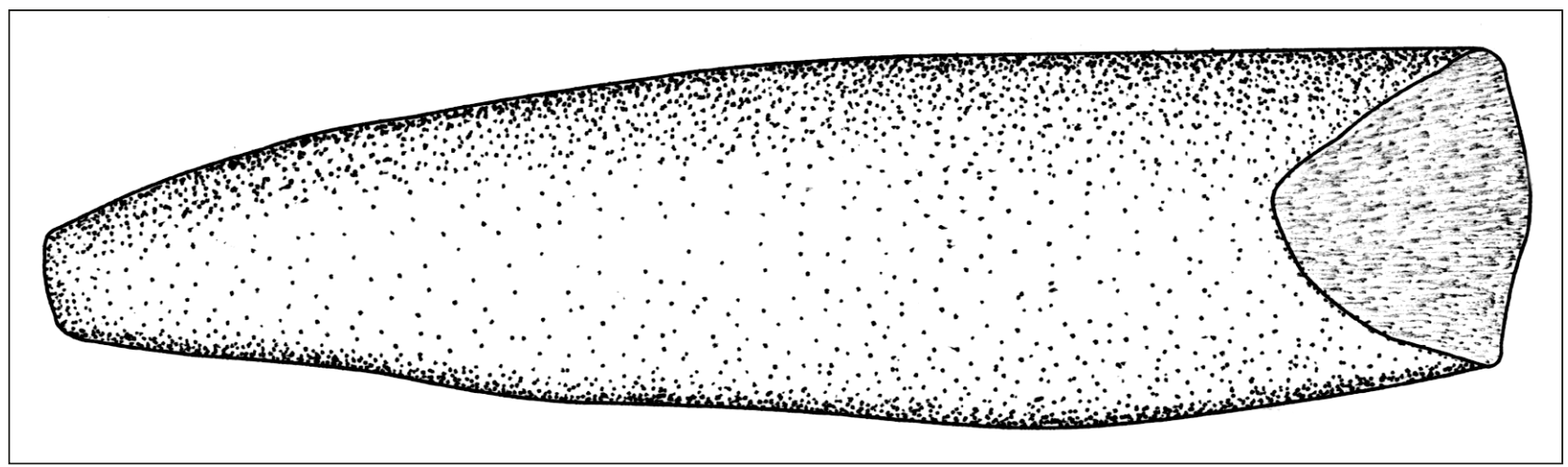

Figure 13. Celt from Burial J-2 at the Eli Moores site.

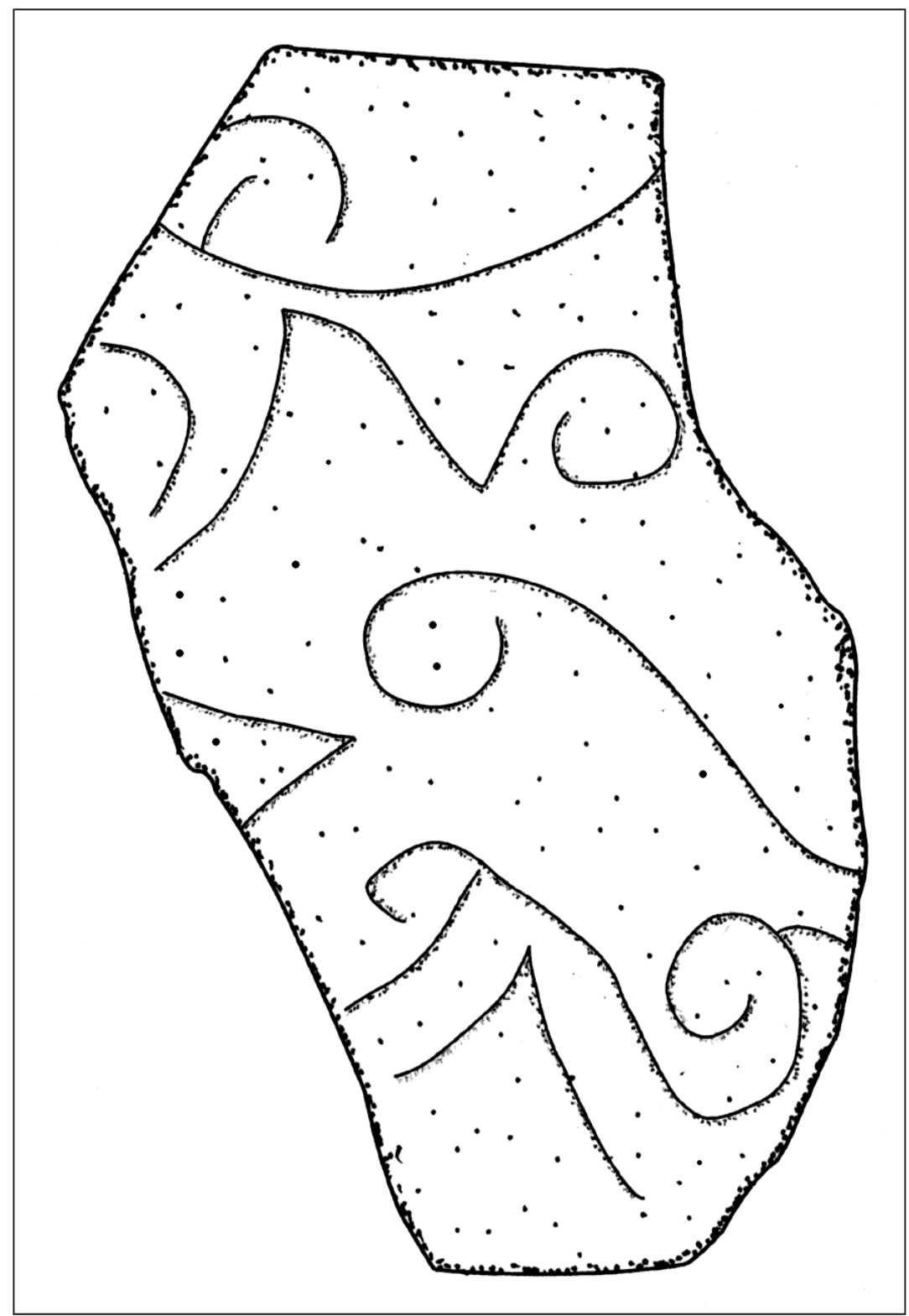

Figure 14. Taylor Engraved vessel section in Burial J-2 at the Eli Moores site. 


\section{$J-3(571 A)$}

Burial J-3 is an adult male, 30-40 years old at death, laying at a depth of $59 \mathrm{~cm}$ bs in its $1.27 \mathrm{~m}$ long grave and on its right side, partially flexed, facing to the east. The ash pit (Feature 2) had bisected the lower legs of the deceased (Figure 15).

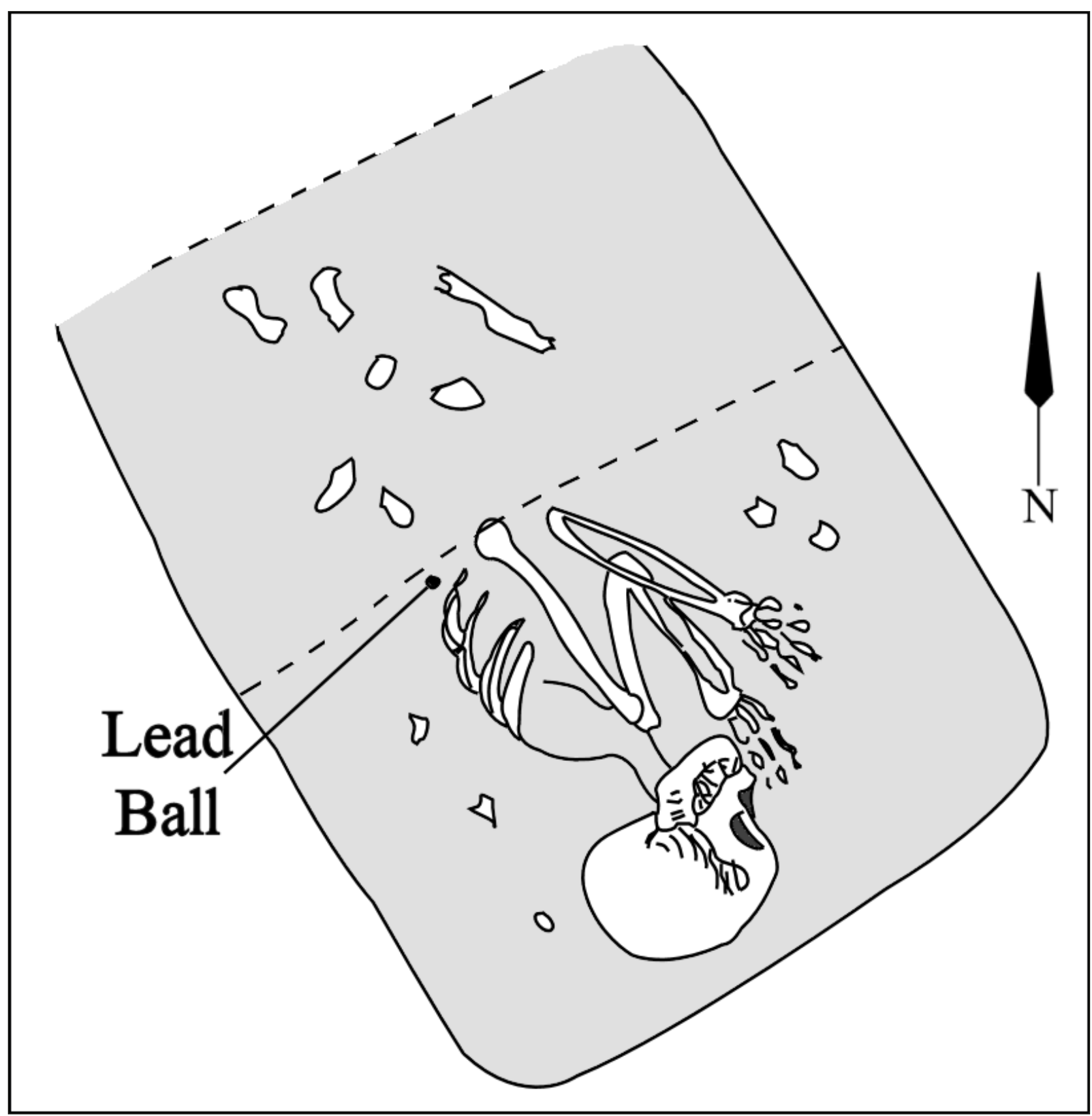

Figure 15. Plan of Burial J-3.

Found in the grave pit was a single bifacially chipped triangular-shaped Maud arrow point preform of Big Fork chert and two lead balls in its rib cage (Jackson 1932:28); there was also a grog-tempered ceramic body sherd with a straight appliqued ridge decoration, probably from the body of a McKinney Plain jar. 
In addition to the two lead balls found in its rib cage or stomach cavity (see Figure 15), that may be the cause of death, this male also had a well-healed fracture of the humerus (Lee 1997:169), Schmorl's nodes (Lee 1997:171 Table 4; the nodes are caused by vertebral disc hernias), and arthritis in the jaw and cervical vertebra (Lee 1997:Table 5). This individual, argued by Gilmore and Gill-King (1991) as being a murdered Frenchman, is most likely a Caddo male, based on dental evidence and cranial/postcranial metrics (Lee 1997:163).

\section{$J-4(3415)$}

Burial J-4 is that of a child about 4 year old at its death. The child was laid east-west in an extended supine position, at a depth of $95 \mathrm{~cm}$ bs, in the grave, with its head facing to the west (Jackson 1932:29) (Figure 16); the burial lay ca. $19 \mathrm{~cm}$ bs below the level of Structure \#1's (Feature 4) exposed post holes. Grave goods placed with the child included an engraved ceramic bottle and a Belcher Engraved compound bowl by the head, a bifacially-chipped Maud arrow point of red jasper by its spine (Figure 17d), and a $15.7 \mathrm{~cm}$ long and $8.0 \mathrm{~mm}$ wide polished bone needle by the right leg; there are use wear marks near the head of the needle (Figure 18).

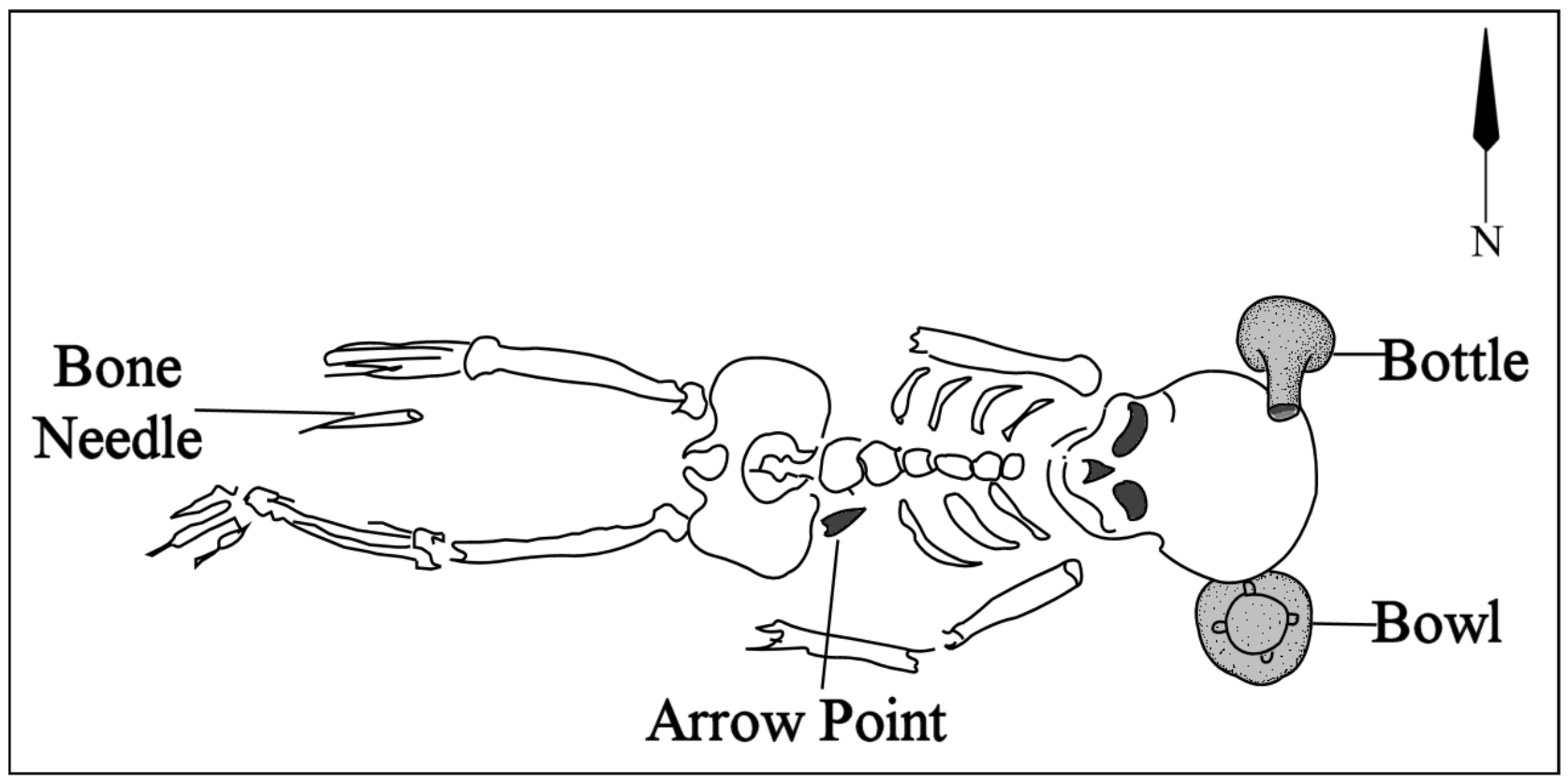

Figure 16. Plan of Burial J-4 at the Eli Moores site.

This burial's skeleton had evidence of cribra orbitalia, a sign of child anemia, as well as dental anomalies (Lee 1997:166, 175). Many sherds and animal bones were in the burial fill.

\section{$J-5$}

This is the burial of a ca. 5-7 year old child (Jackson 1932:35), lying at a depth of $122 \mathrm{~cm}$ bs. This burial pit had been cut into by the Burial J-2 pit, and the Burial J-5 skull lay about $30 \mathrm{~cm}$ below the feet of Burial J-2 (Jackson 1932:35). The skull was at the northern end of the burial pit, apparently facing generally to the southeast (Figure 19). One small appliqued ceramic jar (Artifact 84) was placed as a grave good with Burial J-5, and it rested under the skull. 

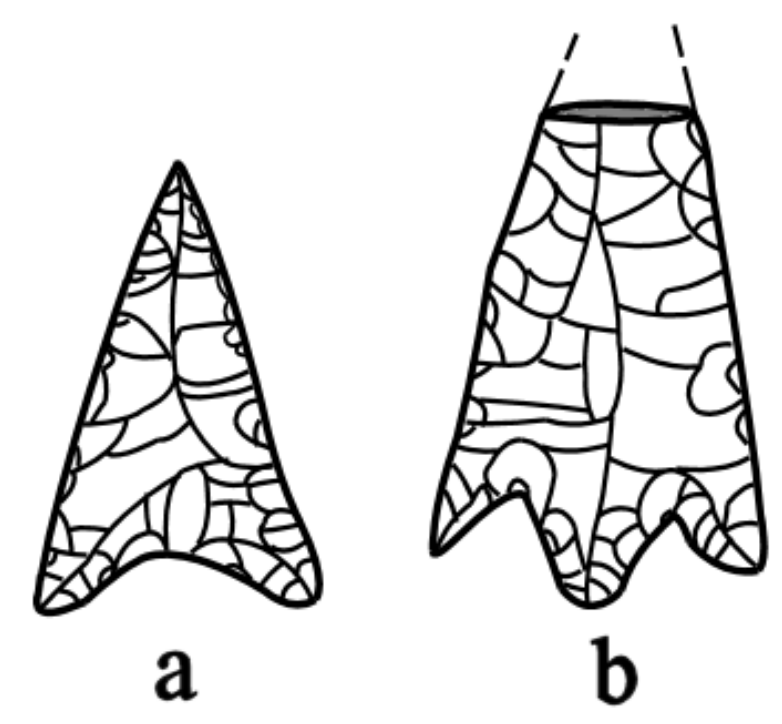

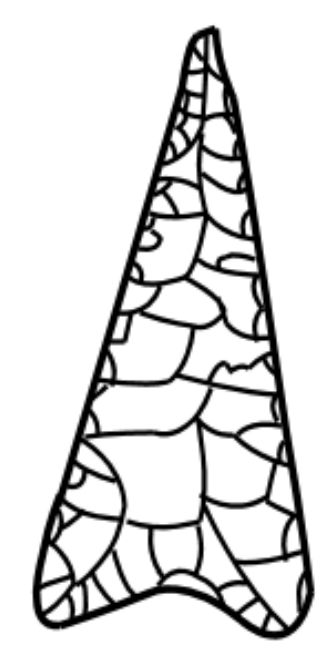

C

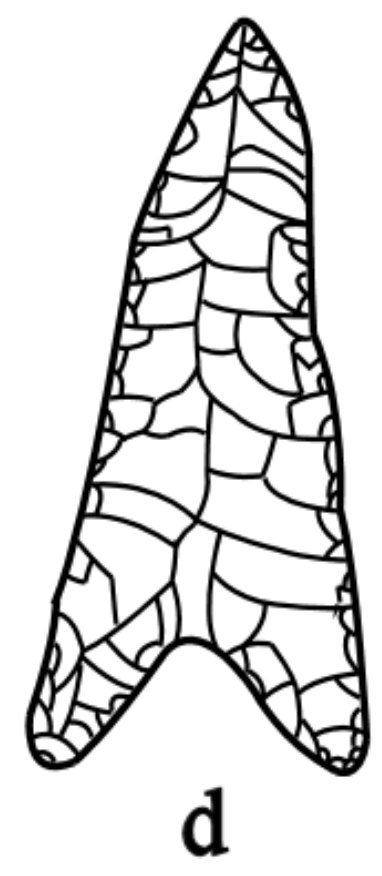

Figure 17. Arrow points in burials from the Eli Moores site: a-b, Burial J-8, Skeleton 2; c, Burial J-8, Skeleton 1; d, Burial J-4.

$J-6(572)$

This is the burial of a child about 6 months of age at death. The child was buried in an extended supine position in a $61 \mathrm{~cm}$ long pit whose base lay at about $107 \mathrm{~cm} \mathrm{bs}$, and it had no associated grave goods. The skull was in the western part of the burial pit (Jackson 1932:36), and the deceased individual faced south-southeast (Figure 20).

\section{$J-7$ (576)}

Burial J-7 is that of a child of undetermined age (possibly ca. 2 years old), buried at a depth of 132 $\mathrm{cm}$ bs (reaching the original A-horizon surface under the mound) in an extended supine position with its head facing to the north (Jackson 1932:36). A portion of a broken ceramic vessel, a very distinctive incised-punctated jar (see below), probably of the Cowhide Stamped type (see Suhm and Jelks 1962:Plate 15a, d), lay nestled along the right shoulder of the child (Figure 21). A broken vessel section of a grogtempered Barkman Engraved carinated bowl (Figure 22) was in the fill of this burial.

\section{$J-8$ (574 and 575)}

This burial had two children in it, one about 2 years of age (Skeleton 1), and the other between 0-6 months of age at death (Skeleton 2). The bottom of the burial pit was at $99 \mathrm{~cm} \mathrm{bs}$, with the heads of the two children at the southern end of the pit, facing west (Jackson 1932:45-47); the younger child appears to have been buried atop the older child (Figure 23). Grave goods found with the two children include two small ceramic vessels, one of which is a Barkman Engraved carinated bowl (Artifact 119) and the other is a plain well-polished bowl (Artifact 126), two Maud arrow points of brown and red jasper (see 


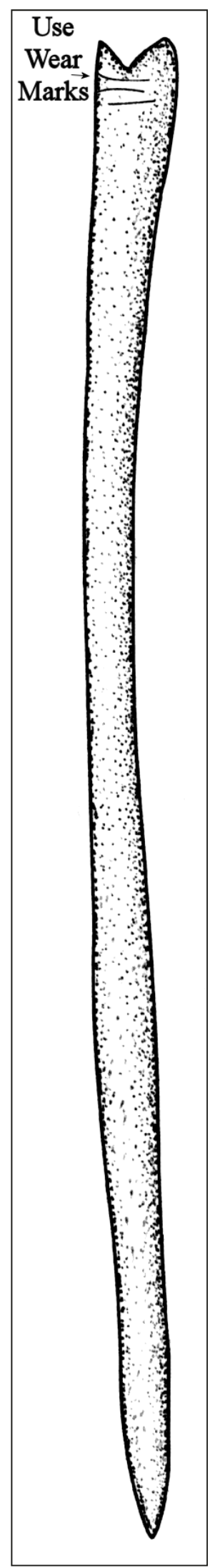

Figure 18. Bone needle in Burial J-4. 


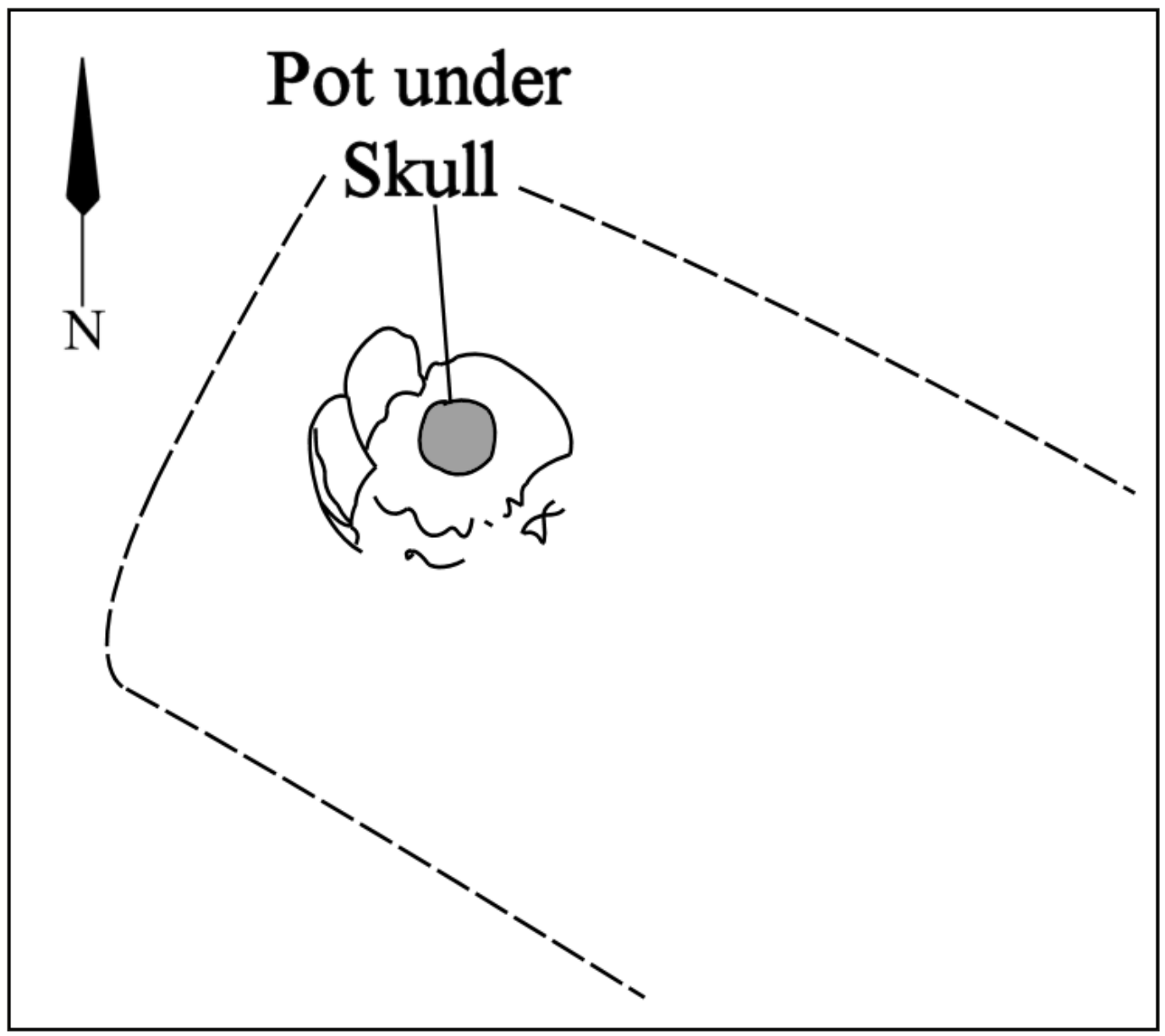

Figure 19. Plan of Burial J-5.

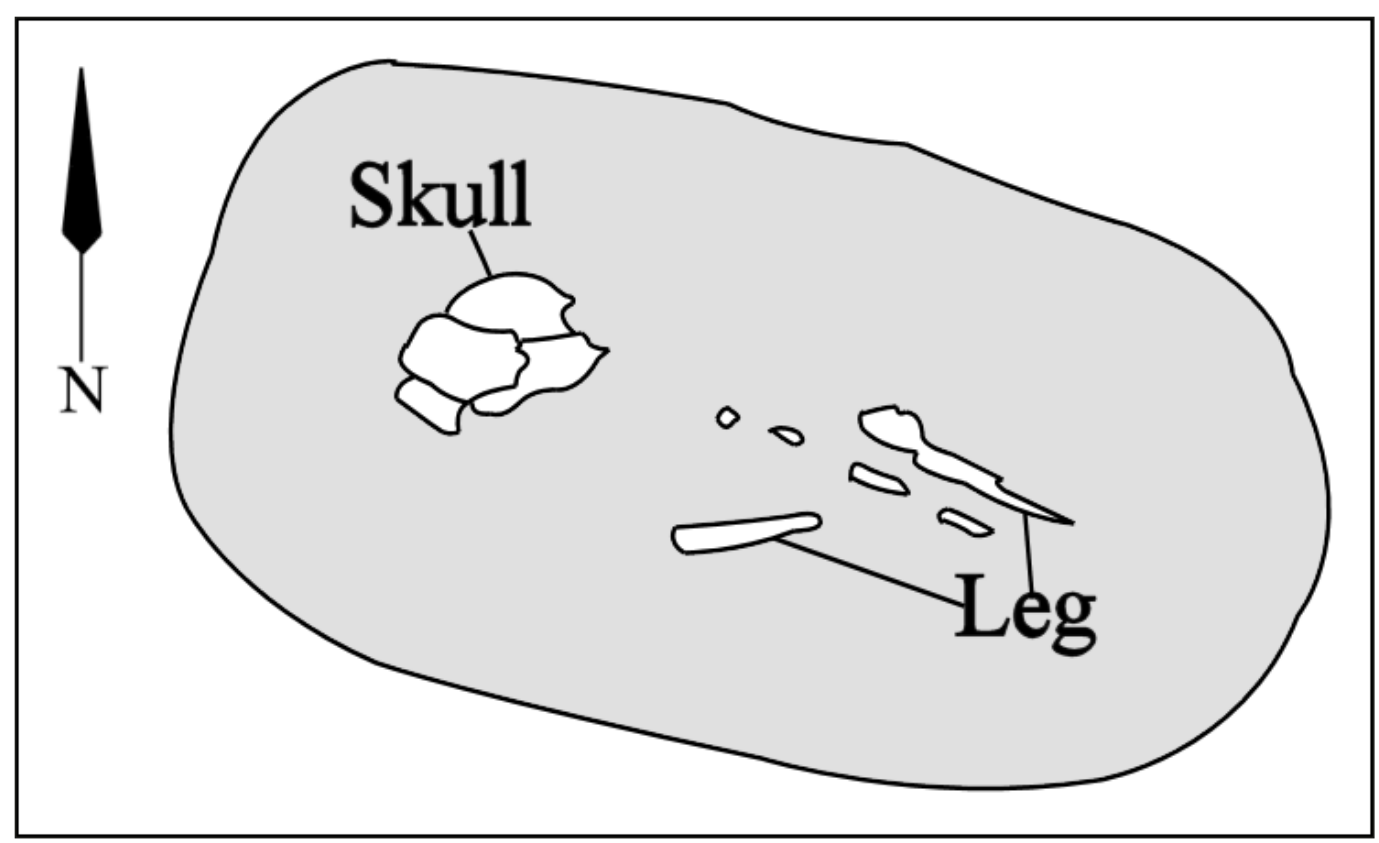

Figure 20. Plan of Burial J-6. 


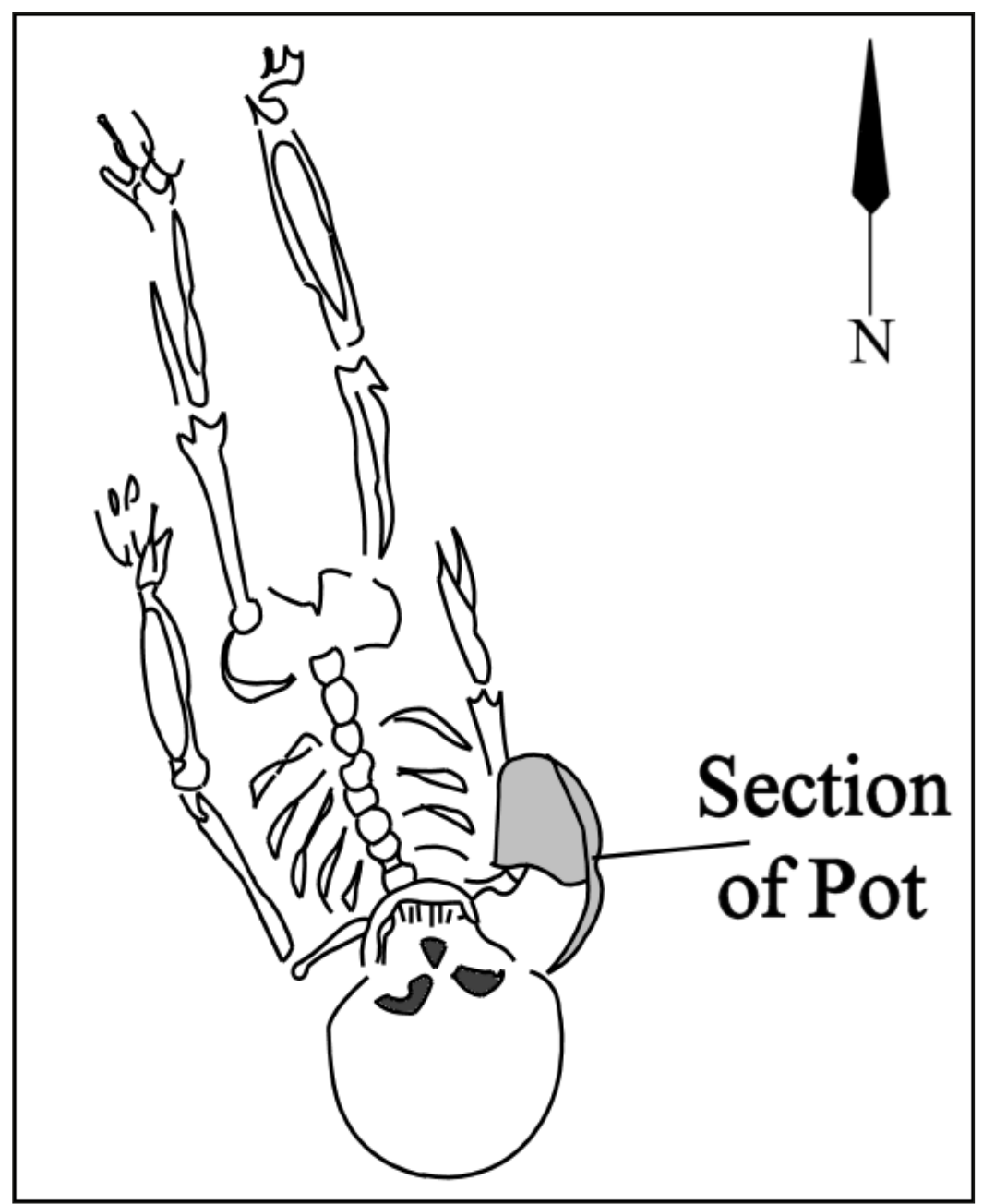

Figure 21. Plan of Burial J-7.

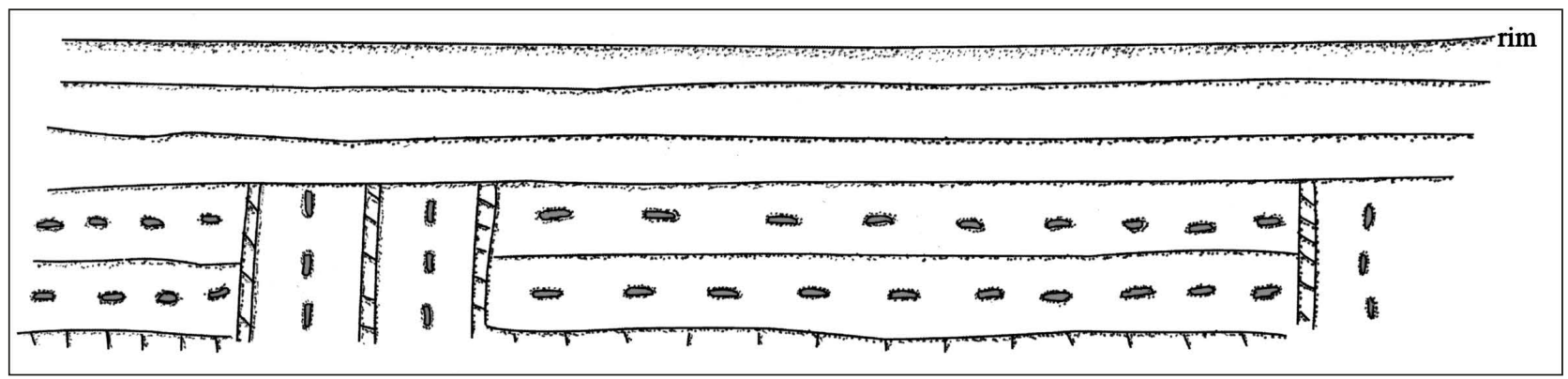

Figure 22. Barkman Engraved vessel section design elements.

Figure 17a, c), one Bassett arrow point of brown jasper (see Figure 17b), a large (23.0 x $20.0 \mathrm{~mm}$ in length and width) conch shell bead (beneath the chin of the older child) and three Olivella sp. shell beads (11.5 mm in length), mussel shells, a drilled turtle shell associated with Skeleton 1 (Figure 24), a deer mandible and several long bones, and a broken but smoothed bacculum bone from a raccoon. The turtle shell carapace is $95.2 \mathrm{~mm}$ in length and $73.0 \mathrm{~mm}$ in width. 


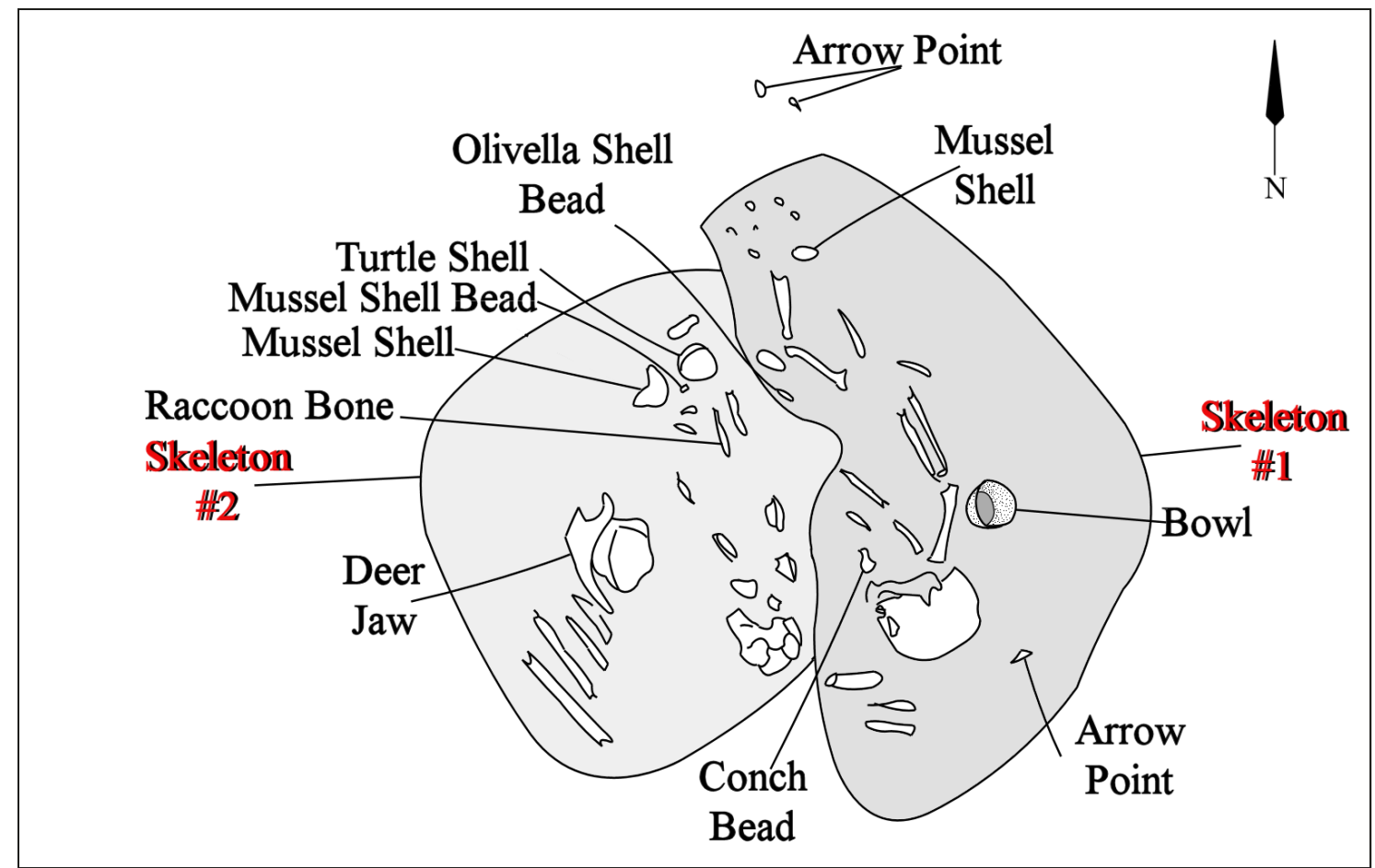

Figure 23. Plan of Burial J-8 at the Eli Moores site.

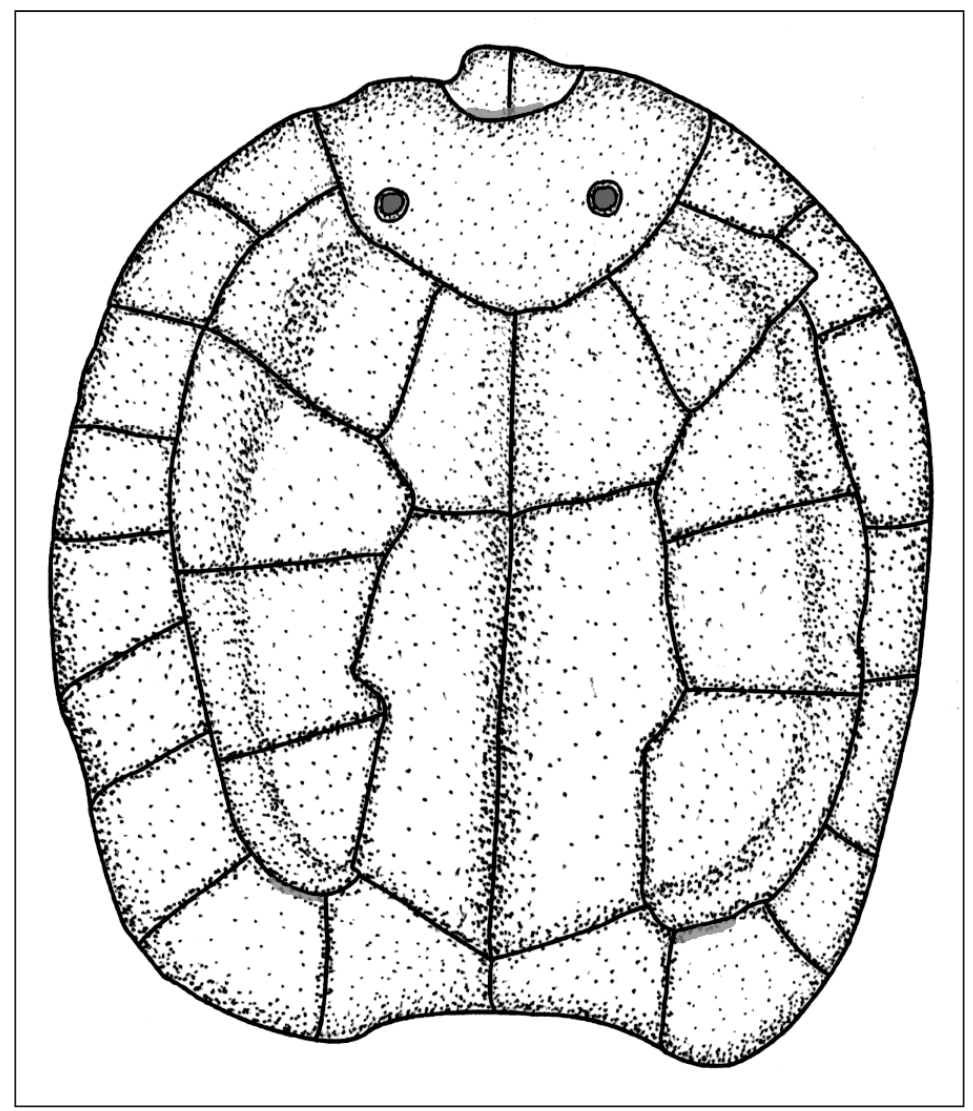

Figure 24. Drilled Turtle shell from Burial J-8, Skeleton 1. 
The slightly older child had evidence of porotic hyperostosis (Lee 1997:166, 173 and Table 3), also a sign of child anemia and compromised immune systems, and periostitis (Lee 1997:Table 6). Lee (1997:173) also suggests that this older child had a case of congenital treponematosis.

\section{Landowner Excavations and Later Investigations}

Mound \#2 was dug into by the landowner, Eli Moores, after the UT work at the site. Moores wrote a letter to A. T. Jackson in 1933, indicating that he had excavated five burials at that time, along with 18 associated ceramic vessels and "several hundred [glass] beads of different kinds, shapes and colors." A small sample of these glass beads $(n=16)$ is in the TARL collections from the site (see below). Moores also found nine metal artifacts, made either from brass, copper, or bronze, with these burials. A 1935 letter from a H. P. Briley to J. E. Pearce stated that Moores continued to dig at the site, and by that time had discovered 10 or 11 burials and additional ceramic vessels.

In 1949, Taylor (1949:25) noted that Mound \#1 only stood ca. $0.6 \mathrm{~m}$ in height because of continued plowing. R. King Harris eventually obtained a small collection of artifacts from the site, as did Pete Miroir, two well-known avocational archaeologists working in the Caddo area. The Harris collection is at the National Museum of Natural History at the Smithsonian Institution. It contains ca. 65 ceramic sherds, several pieces of daub, 11 chipped or ground stone tools (including eight projectile points), three gunflints, four brass tinklers, a necklace of 50 shell beads, and single pieces of sheet brass riveted to an iron piece, an iron nail fragment, and a piece of scrap iron (Dorothy Lippert, November 12, 2013 personal communication). 


\section{Chapter 3, Material Culture Remains}

\section{Ceramic Analysis}

The analysis of the ceramic vessels and sherds from the 1932 excavations at the Eli Moores site focuses primarily on the stylistic character of the utility ware and fine ware assemblage, along with an examination of the rim and lip profile of the plain ware rims, and an assessment of the use of shell and bone temper by Caddo potters that lived at the site and in the larger Nasoni Caddo community.

\section{Ceramic Vessels and Vessel Sections}

There are 10 ceramic vessels in the collections from the Eli Moores site. Seven of the vessels are from five different burials (J-2, J-4, J-5, J-7, and J-8), two others are from "general digging" contexts in the mound (see Jackson 1932), and one partial vessel is from an uncertain context. In general, the vessels are rather small in size-some approaching miniature forms - which is consistent with their being funerary offerings for Caddo children and adolescents.

The two plain vessels in the assemblage include a plain, burnished bowl or jar from Burial J-7 (Figure 25a) and a compound bowl (Figure 25b) found in what Jackson (1932) described as general diggings; in other words, it was not clearly found in funerary context.
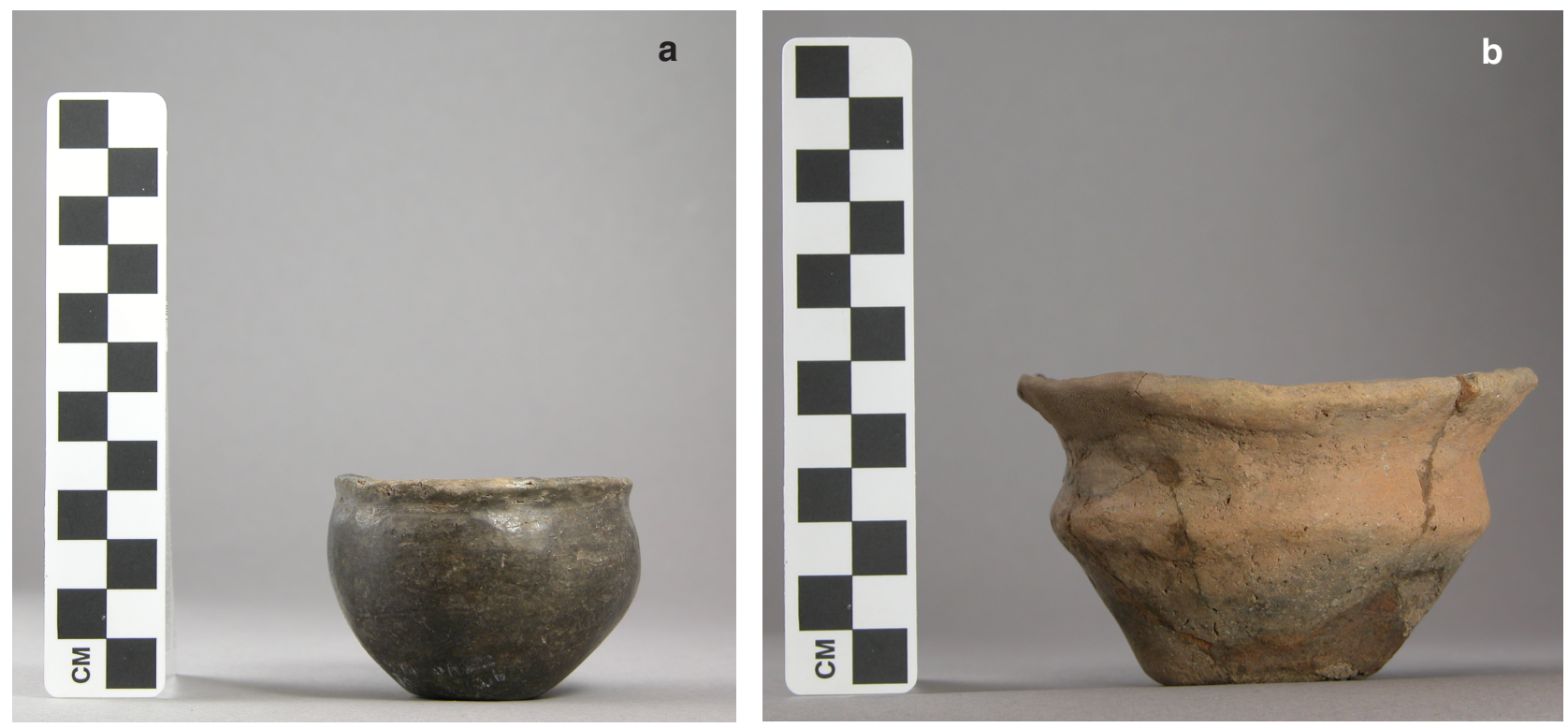

Figure 25. Plain ware vessels from the Eli Moores site: a, bowl or jar, Burial J-7; b, Artifact \#88, general digging. Photographs courtesy of TARL.

Two of the three utility ware vessels are from burials. The first is a small jar from Burial J-2 with three rows of tool punctates around the rim, and a series of vertical incised lines on the vessel body (Figure 26a). The second is a small jar in Burial J-5 with a plain rim and four equally-spaced appliqued nodes on the vessel body (Figure 26b). The third is a vertical brushed-incised Karnack Brushed-Incised jar with a missing rim (Figure 26c). The provenience of this vessel at the site is not known, although it is possible it is from Burial J-1 (see above). 

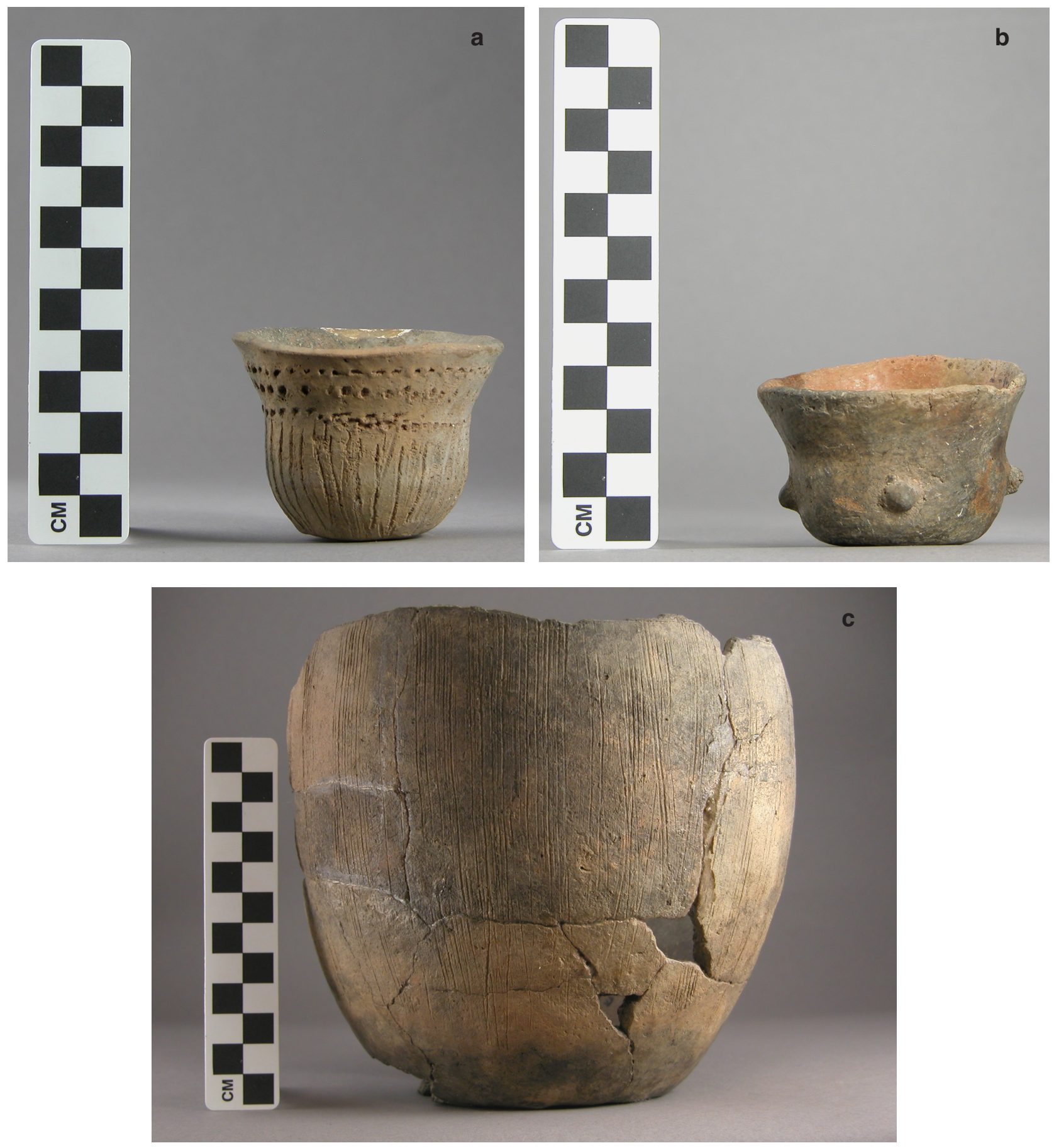

Figure 26. Utility ware vessels from the Eli Moores site: a, incised-punctated jar, Burial J-2; b, appliqued jar from Burial J-5; c, lower body section of Karnack Brushed-Incised jar. Photographs courtesy of TARL.

The other five vessels from the Eli Moores site are fine wares with engraved designs. This includes an inverted rim Simms Engraved carinated bowl from Burial J-2 (Figure 27a); an engraved bottle with open pendant triangle elements on the body (Figure 27b) and a Belcher Engraved, var. Belcher compound bowl (see Schambach and Miller 1984:120 and Figure 11-11) (Figure 27c) from Burial J-4; and a Barkman Engraved carinated bowl from Burial J-8 (Figure 27d). This vessel has had a white kaolin clay 

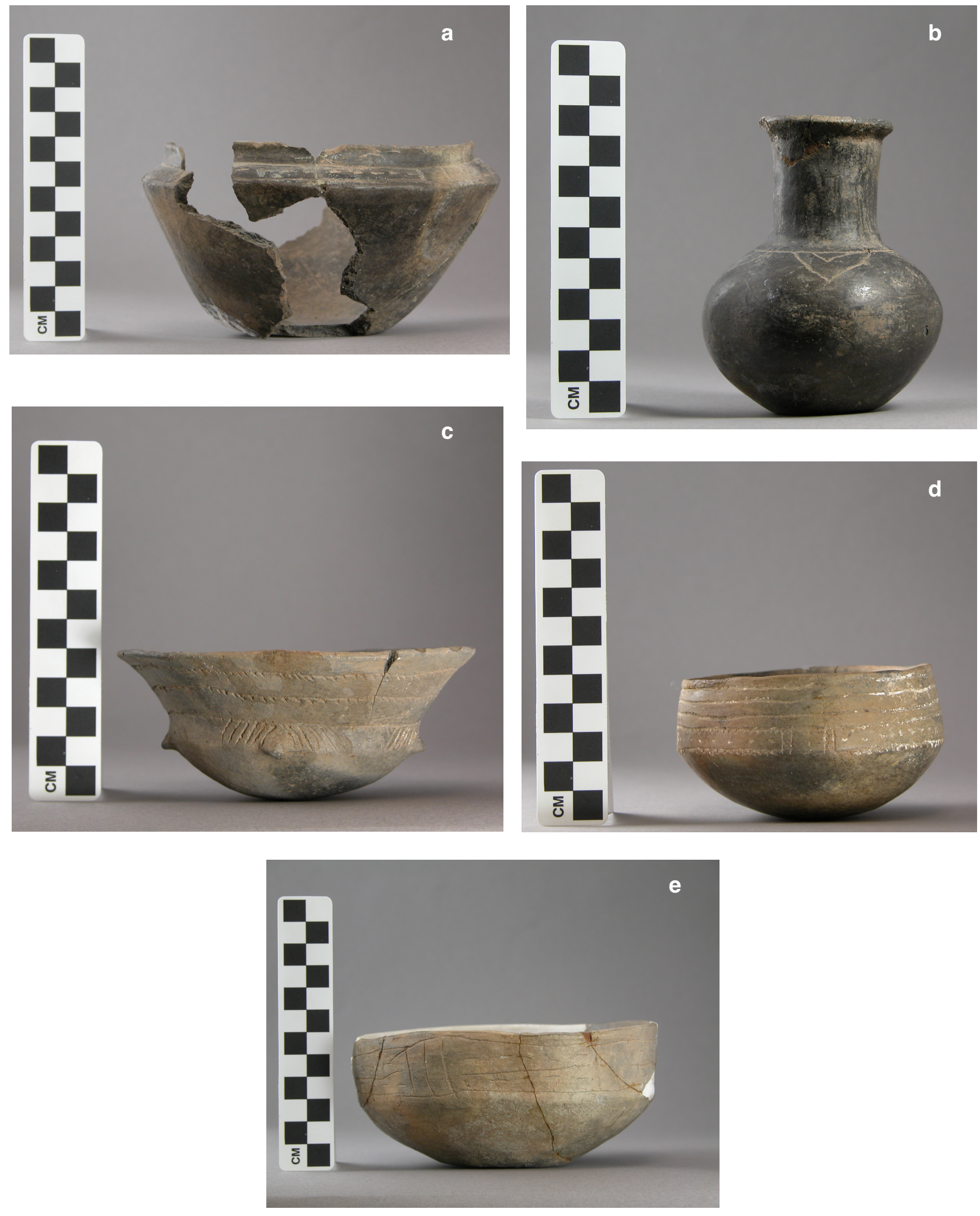

Figure 27. Fine ware vessels from the Eli Moores site: a, Simms Engraved carinated bowl, Burial J-2; b, Engraved bottle from Burial J-4; c, Belcher Engraved, var. Belcher compound bowl from Burial J-4; d, Barkman Engraved carinated bowl from Burial J-8; e. Barkman Engraved carinated bowl, \#178. Photographs courtesy of TARL. 
pigment rubbed in the engraved lines. Another Barkman Engraved carinated bowl (Figure 27e) was found in general digging in the mound at the Eli Moores site (see Jackson 1932).

The range of plain and decorated vessels from mound and burial contexts at the Eli Moores site is consistent with the assemblage of plain and decorated sherds discarded in midden and mound fill deposits at the site (see below). They are from contexts that could date as early as the 15th to early 16th century (Burial J-8, based on the Barkman Engraved carinated bowl left as a funerary offering in the grave) to later in the 16th and 17th centuries in the case of the vessels from the other burials.

\section{Plain Rim Sherds}

Plain rims are common $(n=111)$ in the Eli Moores ceramic assemblage, suggesting that plain ware vessels (jars, bowls, and bottles) were a significant component of the overall assemblage made and used at the site. These plain rims represent 27.4 percent of all the rims in the ceramic collection; utility ware rims account for 19.5 percent of the sample, and 53.2 percent of the rims are from fine ware vessels.

Approximately 9.0 percent of the rims are from bone-tempered vessels and 3.6 percent are from shell-tempered vessels. The remaining 87.4 percent are from grog-tempered wares.

More than 65 percent of the plain rims have a direct profile and a rounded lip (Table 1), and almost 74 percent of the plain rims have a direct or vertical profile; the remainder of the plain ware rims have everted rims and rounded lips. These rims are likely from jars, while the plain rims with direct profiles are from bowls, bottles, and jars. One small plain jar vessel section has an everted rim, rounded lip, and an estimated $5.5 \mathrm{~cm}$ orifice diameter.

Table 1. Rim and lip profiles for the plain ware, utility ware, and fine ware rim sherds in the Eli Moores ceramic assemblage.

\begin{tabular}{|c|c|c|c|c|}
\hline Rim-lip profile & $\begin{array}{l}\text { Plain } \\
\text { ware }\end{array}$ & $\begin{array}{l}\text { Utility } \\
\text { ware }\end{array}$ & $\begin{array}{l}\text { Fine } \\
\text { ware }\end{array}$ & $\mathrm{N}$ \\
\hline Direct rim-rounded lip & $65.5 *$ & 46.2 & 56.1 & 219 \\
\hline $\begin{array}{l}\text { Direct rim-rounded, ext. } \\
\text { folded lip }\end{array}$ & 6.4 & 6.4 & 26.7 & 60 \\
\hline Direct rim-flat lip & 1.8 & 1.3 & 0.6 & 4 \\
\hline Everted rim-rounded lip & 26.4 & 35.9 & 1.7 & 60 \\
\hline $\begin{array}{l}\text { Everted rim-rounded, ext. } \\
\text { folded lip }\end{array}$ & - & 3.8 & 0.6 & 4 \\
\hline $\begin{array}{l}\text { Inverted rim-rounded, ext. } \\
\text { folded lip }\end{array}$ & - & - & 5.6 & 10 \\
\hline $\begin{array}{l}\text { Inverted-direct rim- } \\
\text { rounded lip }\end{array}$ & - & - & 3.3 & 6 \\
\hline $\begin{array}{l}\text { Inverted-direct rim- } \\
\text { flat lip }\end{array}$ & - & - & 1.1 & 2 \\
\hline $\begin{array}{l}\text { Inverted-everted rim- } \\
\text { rounded lip }\end{array}$ & - & - & 4.4 & 8 \\
\hline
\end{tabular}


Table 1. Rim and lip profiles for the plain ware, utility ware, and fine ware rim sherds in the Eli Moores ceramic assemblage, cont.

\begin{tabular}{lrccc}
\hline Rim-lip profile & $\begin{array}{c}\text { Plain } \\
\text { ware }\end{array}$ & $\begin{array}{c}\text { Utility } \\
\text { ware }\end{array}$ & $\begin{array}{c}\text { Fine } \\
\text { ware }\end{array}$ & N \\
\hline --rounded lip & - & 3.8 & - & 3 \\
--rounded, ext. folded lip & - & 2.6 & - & 2 \\
\hline Totals & 110 & 78 & 180 & 368 \\
\hline
\end{tabular}

*percentage

The utility wares are more equally divided between rims with direct (53.9 percent) or everted (39.7 percent) profiles than are either the plain wares or the fine wares (see Table 1). A moderate number of utility ware rims have exterior folded lips (12.8 percent). The fine ware rims are predominantly direct in profile (83.4 percent), but a number of rims (14.4 percent) - from Simms Engraved carinated bowl-have compound rims with inverted and/or direct or everted rim panels in profile (see Table 1). Fine ware rims at the Eli Moores site also are characterized by a high proportion of exterior folded lips (32.9 percent), 2-5 times higher in proportion, than the utility wares or plain wares in the assemblage.

Comparing the proportion of sherds from bone-tempered and shell-tempered vessels included in the plain wares, utility wares, and fine wares in the Eli Moores ceramic assemblage indicates that there is little significant difference between the wares in the use of these tempers (Table 2): between 8.3-11.7 percent of the sherds in the three wares are from bone-tempered vessels and 3.6-8.3 percent of the sherds in the wares are from shell-tempered vessels. The low percentages of shell-tempered sherds in the ceramic assemblage suggests that they are from vessels made in other Caddo ceramic production areas on the Red River where the use of shell temper was considerable from as early as ca. A.D. 1300 or thereabouts (cf. Perttula et al. 2012), including the middle Red River and McCurtain phase Caddo groups and among certain post-A.D. 1500 Belcher phase Caddo groups in the Great Bend area (see Webb 1959; Schambach and Miller 1984).

Table 2. Use of bone and shell temper in the ceramic wares at the Eli Moores site.

\begin{tabular}{lccc}
\hline Wares & \% Bone temper & \% Shell temper & $\mathrm{N}$ \\
\hline Plain ware* & 11.7 & 3.6 & 196 \\
Utility ware & 8.3 & 8.3 & 554 \\
Fine ware & 9.6 & 4.0 & 669 \\
\hline Totals & $9.4 \%$ & $5.7 \%$ & 1419
\end{tabular}

*includes plain rims, base sherds, and spindle whorls

In the case of the utility wares, shell-tempered sherds are most prevalent among those with brushed (16.2 percent) and tool punctated (28.9 percent) decorations. In the fine wares, engraved-red-slipped sherds (several of which are from Hodges Engraved vessels) are very commonly shell-tempered (58.3 percent), and 24.0 percent of the red-slipped sherds are from shell-tempered vessels; by contrast, only 2.4 percent of the engraved sherds have shell temper. 
In the utility wares, brushed (12.4 percent) and tool punctated (13.2 percent) sherds most commonly are from bone-tempered vessels. Red-slipped, engraved-lip notched, engraved-red-slipped, and engravedred-slipped-lip notched sherds are commonly bone-tempered (22.5 percent of the 40 sherds in these categories). Bone-tempered sherds comprise only 8.9 percent of the remainder of the engraved and trailed fine wares.

\section{Decorated Rim and Body Sherds}

The stylistic analysis of Caddo ceramics from the Eli Moores site focuses on the definition of recognizable decorative motifs and elements in the fine wares (i.e., the engraved and red-slipped vessels, including carinated bowls and bottles) and utility wares, usually cooking or storage jars and simple bowls. These wares are known to have been made and used differently, based on functional, technological, and stylistic analyses on numerous Caddo sherd assemblages in the broader East Texas region, with uses ranging from food service, cooking of food stuffs, as containers for liquids, and for plant food/seed crop storage. The more detailed consideration of ceramic stylistic variability and diversity in the Eli Moores ceramic assemblage focuses on decorative elements that can be identified on rim and body sherds. These represent distinct designs or design combinations and elements (i.e., the breakdown of individual decorations within an overall design motif, as in a hatched triangle, circle, or tick marks) that can be identified on sherds and vessel sections (even if it is only a portion of the element), as a recurrent feature of decoration within each of the major decorative methods (e.g., incising, punctating, engraving, etc.) present in the Caddo ceramic assemblage. The design elements are defined at different levels of association, depending upon variations in the designs (e.g., the number and spacing of engraved lines on a rim), the location of the decoration (e.g., on the rim, body, on the vessel interior, etc.), and the method of decoration (e.g., horizontal vs. vertical brushing). When sherds large enough to exhibit overall design motifs are present in the assemblage, typological classifications are possible.

The utility ware vessels found on ancestral Caddo sites in East Texas were used for cooking, storage, and probably other culinary activities; they tend to have a coarse paste, thick or thicker body walls, have smoothed interior surfaces, and are decorated with wet-paste designs (i.e., decorations were made with tools and fingers prior to the vessel being fired, when the vessel had a wet exterior surface) (Perttula 2013). Fine wares are engraved, engraved-punctated, and red-slipped vessels that were used for food service and to hold liquids, as well as for other purposes (i.e., effigy vessels). They tend to have fine pastes, with finely crushed tempers, are frequently burnished on interior and/or exterior vessel surfaces (except the bottles, which were burnished on exterior surfaces only), and have relatively thin body walls compared to the utility wares. The engraved decorations are etched into the exterior vessel surface after the vessel has been fired or was leather-hard.

More specifically, the detailed analysis of the decorated ceramic sherds from the Eli Moores site also is based on differences in temper (specifically the presence or absence of bone or shell as a temper, in an otherwise grog temper-dominated assemblage), type of sherd (i.e., rim or body), and rim and lip form (cf. Brown 1996:Figure 2-12). Although most of the sherds are small and thus from indeterminate vessel forms, where sherds were large enough, vessel form categories that could be identified include open containers (bowls and carinated bowls) and restricted containers, including jars and bottles. Other form attributes include rim profile (outflaring or everted, direct or vertical, and inverted) and lip profile (rounded, flat, or folded to the exterior, among others).

Brushing, a popular method of roughening the surface of Middle, Late, and Historic Caddo cooking jars in this part of the Red River basin with stiff bundles of grasses, is considered a decorative treatment here rather than solely a functional surface treatment (cf. Rice 1987:138). A roughened and brushed pot 
would certainly have been easier to pick up and carry than would an unroughened or smoothed vessel, but because the brushing was applied to be an integral part of the decoration of both rim and body vessel surface, I de-emphasize it as a surface treatment.

The application of a hematite-rich clay slip, black after firing in a reducing environment, is another form of surface treatment noted in this assemblage, although it is not common. The clay slip was typically applied to the vessel exterior or both surfaces, and then was burnished or polished after it was leatherhard or dry; when the vessel was fired, it created a thin red slip. In other instances, a kaolin-rich clay (i.e., white pigment) or a hematite-rich clay (i.e., red pigment) may be applied as a pigment to the decoration on engraved ceramic vessels.

Besides sherds with a red slip, decorative techniques present in the Eli Moores site ceramic sherd collections include engraving, incising, trailed, punctation, neck banded, roughened, brushing, and appliqué, and on certain sherds, combinations of decorative techniques (i.e., brushed-incised and brushed-appliqued, or incised-punctated sherds) created the decorative elements and motifs, with one motif on the rim and another on the vessel body (Schambach's Rule of Two). Engraving and the excising of punctations on fine wares was done with a sharp tool when the vessel was either leather-hard or after it was fired, while the other decorative techniques were executed with tools or fingers (incising, trailing, punctations, and pinching with wood or bone sticks or dowels), by adding strips of clay to the wet body (appliqué), using frayed sticks or grass stems (brushing) across the vessel surface, or corrugating vessel coils when the vessel was wet or still plastic to create a series of neck bands. Excising is considered a form of engraved decoration, where the clay is deliberately and closely marked/scraped and carved away with a sharp tool, usually to create triangular elements or crescent-shaped elements separating or defining scrolls. A red clay film or wash may be added to the surface (interior and/or exterior surfaces) of some vessels as a slip (or a coating) before they were fired.

The decorated ceramic assemblage from the 1932 investigations at the Eli Moore site includes 1223 rim and body sherds. No decorated sherdlets (less than $1.5 \mathrm{~cm}$ in diameter) were examined herein. The decorated sherds are divided into utility wares $(n=554,45$ percent of the decorated sherds) and fine wares $(\mathrm{n}=669,55$ percent $)$; the proportion of fine wares is notable.

\section{Utility Wares}

Several different kinds of utility wares are represented in the Eli Moores decorated ceramic sherds. Principal among them are sherds with incised, brushed, appliqued, punctated, and trailed-incised decorative elements (Table 3) from Emory Punctated-Incised, Foster Trailed-Incised, Karnack Brushed-Incised, and McKinney Plain vessels. There are also Nash Neck Banded and Belcher Ridged sherds in the utility wares.

Table 3. Decorative methods represented in the utility wares from the Eli Moores site.

\begin{tabular}{lccrr}
\hline Decorative Method & Rim & Body & $\mathrm{N}$ & $\%$ \\
\hline Appliqued* & 11 & 67 & 78 & 14.1 \\
Appliqued-Incised-Brushed & - & 1 & 1 & 0.2 \\
Appliqued-Punctated & - & 1 & 1 & 0.2 \\
& & & & \\
Brushed & 15 & 90 & 105 & 19.0 \\
Brushed-Appliqued & - & 3 & 3 & 2.7 \\
Brushed-Incised & - & & 3 & 0.5
\end{tabular}


Table 3. Decorative methods represented in the utility wares from the Eli Moores site, cont.

\begin{tabular}{lcccc}
\hline Decorative Method & Rim & Body & $\mathrm{N}$ & $\%$ \\
\hline Brushed-Punctated & 3 & 2 & 5 & 0.9 \\
Brushed-Punctated-Appliqued & - & 1 & 1 & 0.2 \\
Brushed-Punctated-Incised & 1 & - & 1 & 0.2 \\
Incised & $12^{* *}$ & 168 & 180 & 32.5 \\
Incised-Appliqued & 1 & 12 & 13 & 2.4 \\
Incised-Punctated & 1 & 5 & 6 & 0.4 \\
Incised-Punctated-Appliqued & 2 & - & 2 & 0.2 \\
Lip Notched & 1 & - & 1 & 2.2 \\
Neck Banded & 10 & 2 & 12 & 1.6 \\
Punctated, fingernail & 4 & 5 & 9 & 6.9 \\
Punctated, tool & 13 & 25 & 38 & 0.9 \\
Ridged & - & 5 & 5 & 0.4 \\
Roughened & 2 & $-575 *$ & 76 & 13.7 \\
Trailed-Incised & 3 & 554 & 2 \\
\hline Totals & 79 & & & \\
\hline
\end{tabular}

*includes appliqued handles $(\mathrm{n}=4) * *$ one rim also lip notched $* * *$ one sherd reworked into a spindle whorl

\section{Appliqued}

Two everted rim sherds have a mid-rim appliqued loop handle and an appliqued lug. A third rim, from a rim peaked jar, has an appliqued loop handle with appliqued knobs on it. Another appliqued handle is about $22.0 \mathrm{~mm}$ in diameter, and may be part of a Moore Noded vessel. Four rims, from McKinney Plain jars, have vertical appliqued ridges on them (Figure 28d), and another four, likely from Moore Noded bowls, have appliqued nodes on the rim.

The appliqued body sherds, likely from both McKinney Plain and Nash Neck-Banded jars, have appliqued ridges $(n=56)$, appliqued fillets $(n=7)$, vertical appliqued lugs $(n=2)$, and a straight row of appliqued nodes $(n=1)$ (see Figure 28f). Appliqued ridges tend to be vertical in orientation, either singly or in multiple ridges, but two body sherds have concentric appliqued ridges (see Figure 28k) or circles and another body sherd has a V-shaped appliqued ridge. The body sherds with appliqued fillets are straight (or vertical) in orientation.

\section{Appliqued-Incised-Brushed}

This body sherd has a straight appliqued fillet and parallel incised lines adjacent to the fillet. Opposed brushing marks were then drawn over the incised lines. 

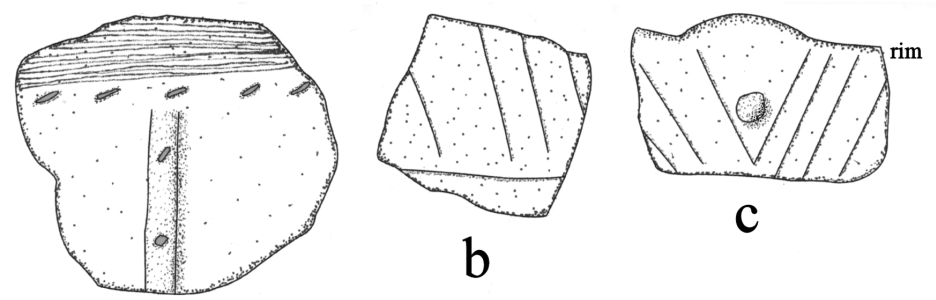

\section{a}
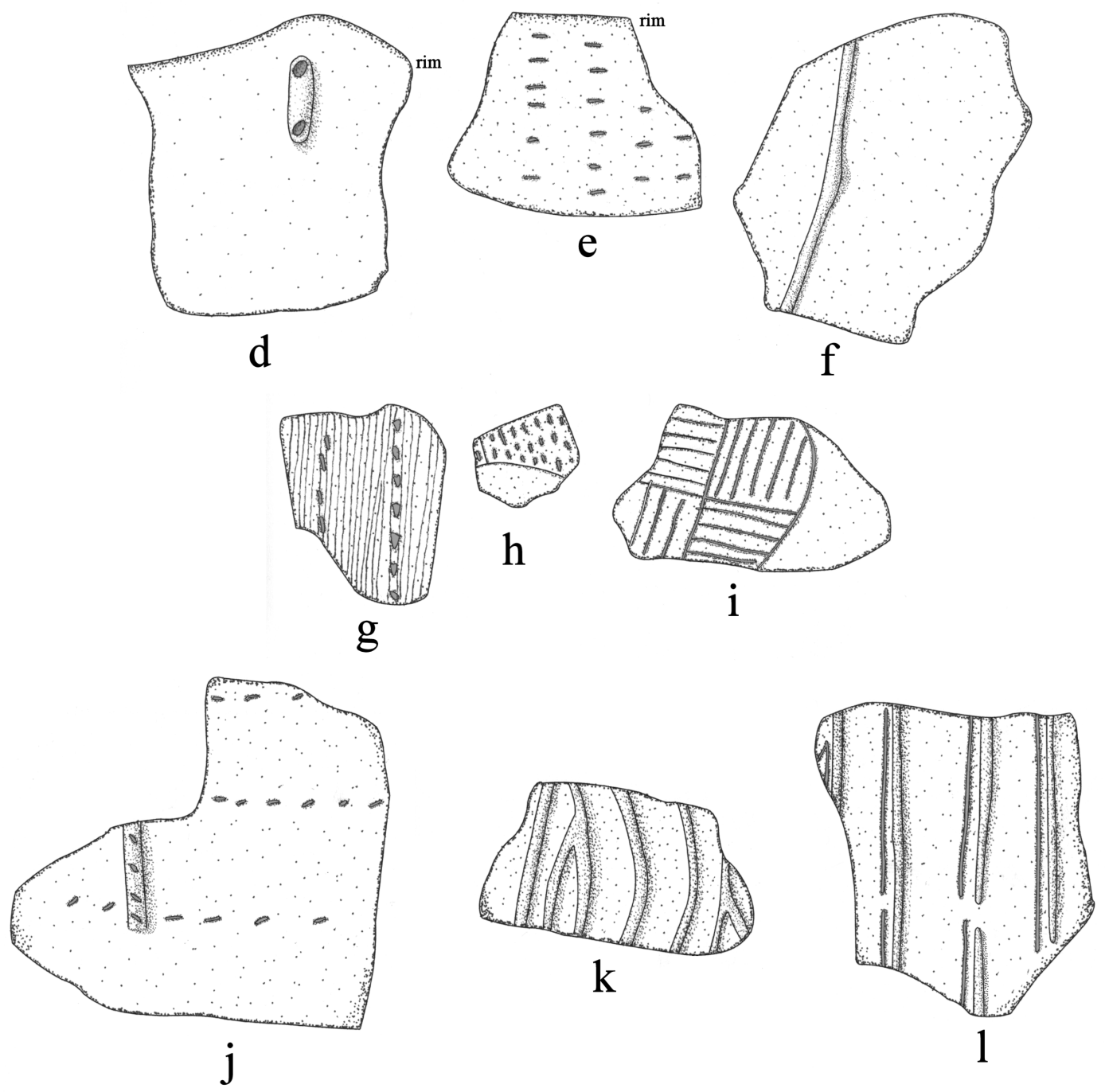

Figure 28. Utility ware rim and body sherds from the Eli Moores site: a, brushed-punctated-appliqued; b, i, incised; c, l, incised-appliqued; d, f, k, appliqued; e, tool punctated; g, brushed-punctated; h, incised-punctated; $\mathbf{j}$, punctated-appliqued.

\section{Appliqued-Punctated}

The one appliqued-punctated sherd in the utility wares is a body sherd with vertical appliqued fillets and horizontal punctated rows (see Figure 28j). This may be from a McKinney Plain vessel (see Suhm and Jelks 1962:97). 


\section{Brushed}

Sherds with brushing marks are probably from Karnack Brushed-Incised jars. These sherds represent approximately 19 percent of the utility wares from the site (see Table 2). Rim sherds have both horizontal $(n=13)$ and vertical $(n=3)$ brushing marks, while almost all of the body sherds $(n=88)$ have parallel or vertical brushing marks that would have covered the vessel body almost down to the base. One body sherd has opposed brushing marks, however.

\section{Brushed-Appliqued}

The brushed-appliqued body sherds $(n=15)$ represent 2.7 percent of the utility wares from the Eli Moores site. Most of the body sherds (73 percent) have straight or parallel appliqued ridges with adjacent areas of parallel brushing, but one sherd has curvilinear brushing marks adjacent to a straight appliqued ridge. Three body sherds have straight appliqued fillets and parallel brushing zones, while one other body sherd has a row of appliqued nodes adjacent to a zone of parallel brushing marks.

\section{Brushed-Incised}

The three brushed-incised body sherds are from Karnack Brushed-Incised vessels. One sherd has opposed brushed marks and incised lines, another has parallel brushing marks and incised lines, while the last has parallel brushing marks with straight incised lines drawn over and through the brushing.

\section{Brushed-Punctated}

The five brushed-punctated sherds, probably from Pease Brushed-Incised vessels, include three rims and two body sherds. All three rims are horizontally brushed, with a row of punctations either at the rimbody juncture, under the vessel lip, or under the vessel lip and at the mid-rim. The body sherds have either parallel or opposed brushing marks with a row of tool punctations pushed through the brushing (see Figure 28g).

\section{Brushed-Punctated-Appliqued}

The one sherd in this decorative category has horizontal brushing on a jar rim, and a diagonal row of tool punctates at the rim-body juncture. The vessel body has vertical appliqued fillets (see Figure 28a) that probably quadrated or divided the body into four separate panels.

\section{Brushed-Punctated-Incised}

This decorative category is represented by a rim-body vessel section of an everted rim jar. Under the lip is a row of diagonal tool punctates, and there is a single horizontal incised line at the rim-body juncture. The remainder of the rim has opposed diagonal brushing marks as well as overlying opposed diagonal and cross-hatched incised lines (Figure 29a). The vessel body has vertical brushing marks.

\section{Incised}

Sherds with incised decorative elements are the most commonly represented in the utility wares from the Eli Moores site; they account for approximately 33 percent of the utility wares from the site. The incised rim sherds have different horizontal and diagonal elements (Table 4), and one of the rims is lip 


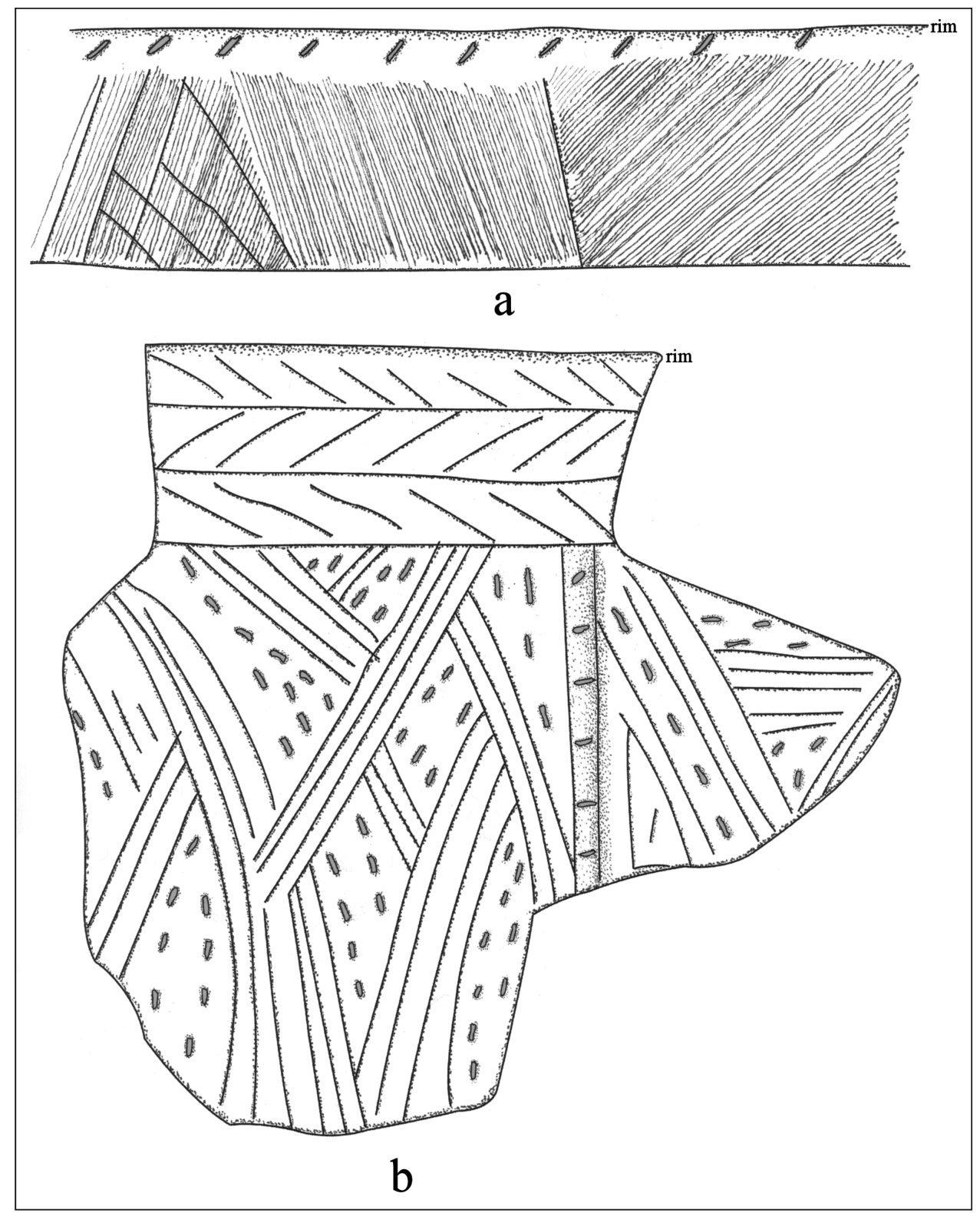

Figure 29. Utility ware vessel sections from the Eli Moores site: a, Brushedpunctated-incised jar vessel section; $b$, incised-punctated-appliqued vessel section.

notched. These rims are likely from several Foster Trailed-Incised jars, either grog or shell-tempered, including var. Foster, var. Dobson, var. Red Lake, or var. Dixon (see Schambach and Miller 1984:121 and Figure 11-10).

Table 4. Incised decorative elements in the Eli Moores site utility wares.

\begin{tabular}{lccc}
\hline Decorative element & Rim & Body & N \\
\hline Circle filled with hatched incised zones & - & 1 & 1 \\
Curvilinear lines & - & $12 *$ & 12 \\
Diagonal curvilinear lines & 2 & - & 2
\end{tabular}


Table 4. Incised decorative elements in the Eli Moores site utility wares, cont.

\begin{tabular}{lccc}
\hline Decorative element & Rim & Body & N \\
\hline Diagonal lines & $4 *+$ & 3 & 7 \\
Diagonal opposed lines & - & 16 & 16 \\
Diagonal opposed-curvilinear lines & - & $1 * *$ & 1 \\
Horizontal lines & 1 & 2 & 3 \\
Horizontal and diagonal lines & 5 & 2 & 7 \\
Horizontal and diagonal opposed lines & - & 1 & 1 \\
Opposed lines & - & 1 & 6 \\
Opposed curvilinear lines & - & $99 *$ & 1 \\
Parallel lines & - & 7 & 99 \\
Straight line & - & $17 *$ & 7 \\
Vertical lines & - & 168 & 17 \\
\hline Totals & 12 & 180 \\
\hline
\end{tabular}

*includes shell-tempered sherds

**vessel section

+one of the rims is also lip notched

One lower rim-body vessel section (see Table 4) from a vessel of undetermined type has diagonal opposed incised lines on the rim, as well as two horizontal lines at the rim-body juncture. The vessel body has widely-spaced curvilinear zones and sets of diagonal incised lines.

Incised body sherds in the Eli Moores utility wares are dominated by straight line elements as well as opposed straight line elements (see Figure $28 \mathrm{~b}$ and Table 4), primarily from grog-tempered vessels, but shell-tempered incised body sherds are also present in low frequencies. Vertical incised lines on body sherds likely are from Karnack Brushed-Incised jars, while curvilinear incised elements are from the bodies of most varieties of Foster Trailed-Incised jars (see Schambach and Miller 1984:Figure 11-10).

\section{Incised-Appliqued}

This decorative category is represented by one rim sherd and 12 body sherds. The rim is from a peaked jar with diagonal opposed incised lines on either side of an appliqued knob; the knobs were likely repeated four times around the rim (see Figure 28c).

Three body sherds are from Foster Trailed-Incised jars: they have concentric curvilinear incised lines around a central cluster of appliqued nodes (see Suhm and Jelks 1962:Plate 22e-f, i-k and Schambach and Miller 1984:Figure 11-10) (Figure 30h-i). The other body sherds $(n=9)$ have either straight or parallel appliqued ridges (89 percent) or fillets (11 percent) with straight or parallel incised lines on either side of the appliqued elements.

\section{Incised-Punctated}

The largest of the incised-punctated sherds is a Cowhide Stamped vessel section (see Webb 1959) from the fill of Burial J-7. This jar has upper rectilinear incised panels filled with small tool punctates and lower curvilinear and concentric incised panels filled with small tool punctates (Figure 31). The other incised-punctated sherds, none identified to a defined Caddo type, in the assemblage include: 


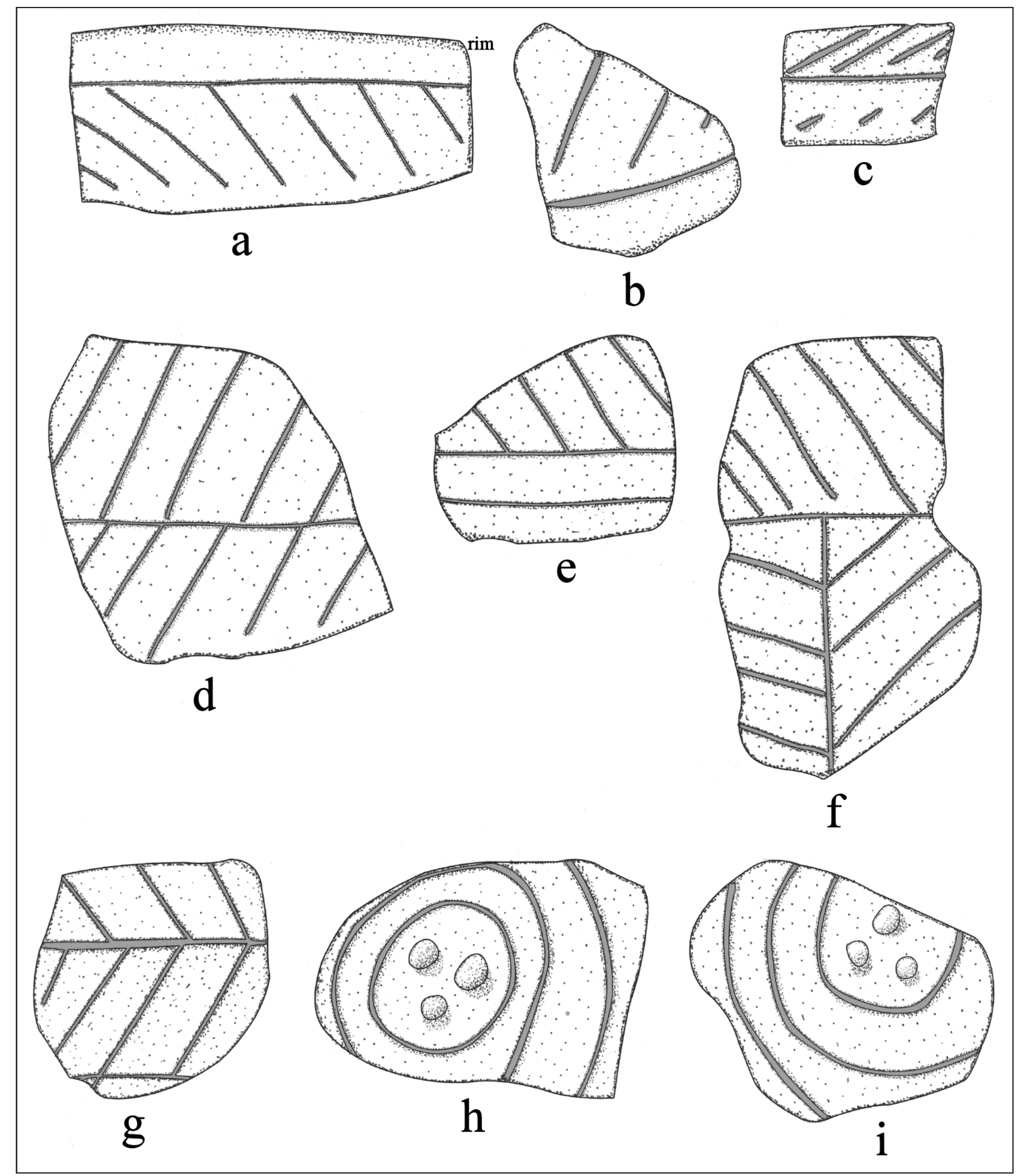

Figure 30. Foster Trailed-Incised rim and body sherds.

- a body sherd with a curvilinear incised zone filled with tool punctates (see Figure 28h);

- a lower rim sherd with diagonal incised lines above a row of tool punctates at the rim-body juncture;

- a lower rim/body sherd with fingernail punctated rows on the rim and a horizontal incised line at the rim-body juncture; this sherd is from a shell-tempered vessel; 
- a rim sherd with a row of fingernail punctates at the mid-rim, and a horizontal incised line at the rim-body juncture; and

- a body sherd with a curvilinear incised zone filled with rows of linear tool punctates.

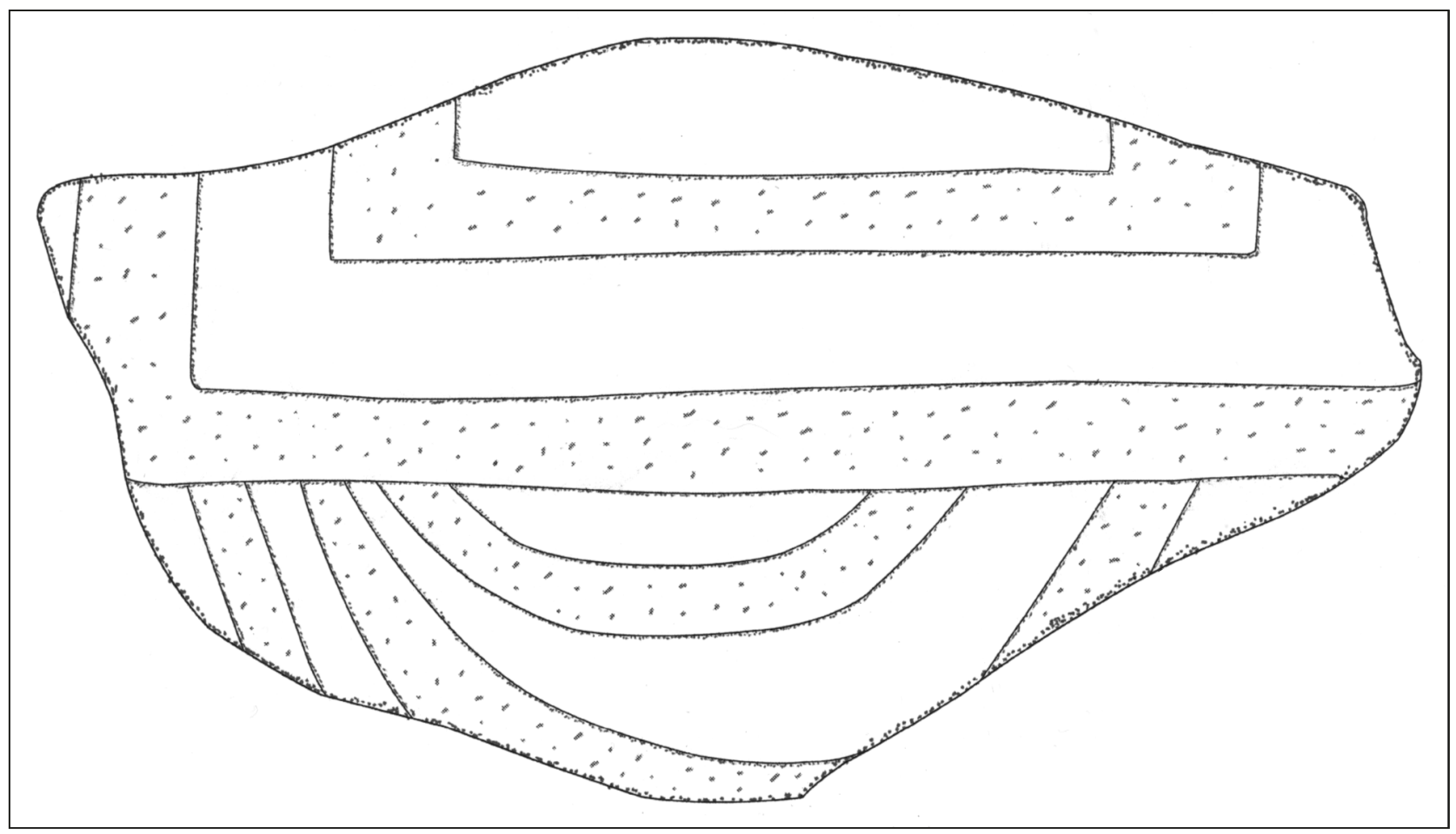

Figure 31. Cowhide Stamped vessel section from the fill of Burial J-7.

\section{Incised-Punctated-Appliqued}

One of these sherds consists of a substantial rim (direct rim and a rounded lip) and body section of a probable Foster Trailed-Incised jar, at least based on the rim decorative treatment. The rim has three horizontal incised bands filled with hatched lines pitched in opposite directions. The vessel body has sets of interlocking diagonal incised lines with rectangular areas in between that are filled with one or two rows of tool punctations. The incised and punctated lines and zones are in panels divided by vertical appliqued fillets (see Figure 29b).

The other incised-punctated-appliqued sherd is represented by another vessel section from a Foster Trailed-Incised jar that has four horizontal incised bands filled with diagonal incised lines on the rim, and concentric incised circles on the vessel body. Within each of the innermost incised concentric circles are two appliqued nodes. The space between the concentric incised circles is filled with circular tool punctations (Figure 32; see also Figure 30h-i).

\section{Lip Notched}

The single lip notched sherd is an otherwise plain rim with a direct profile and a flat lip. The sherd is probably from a bowl. 


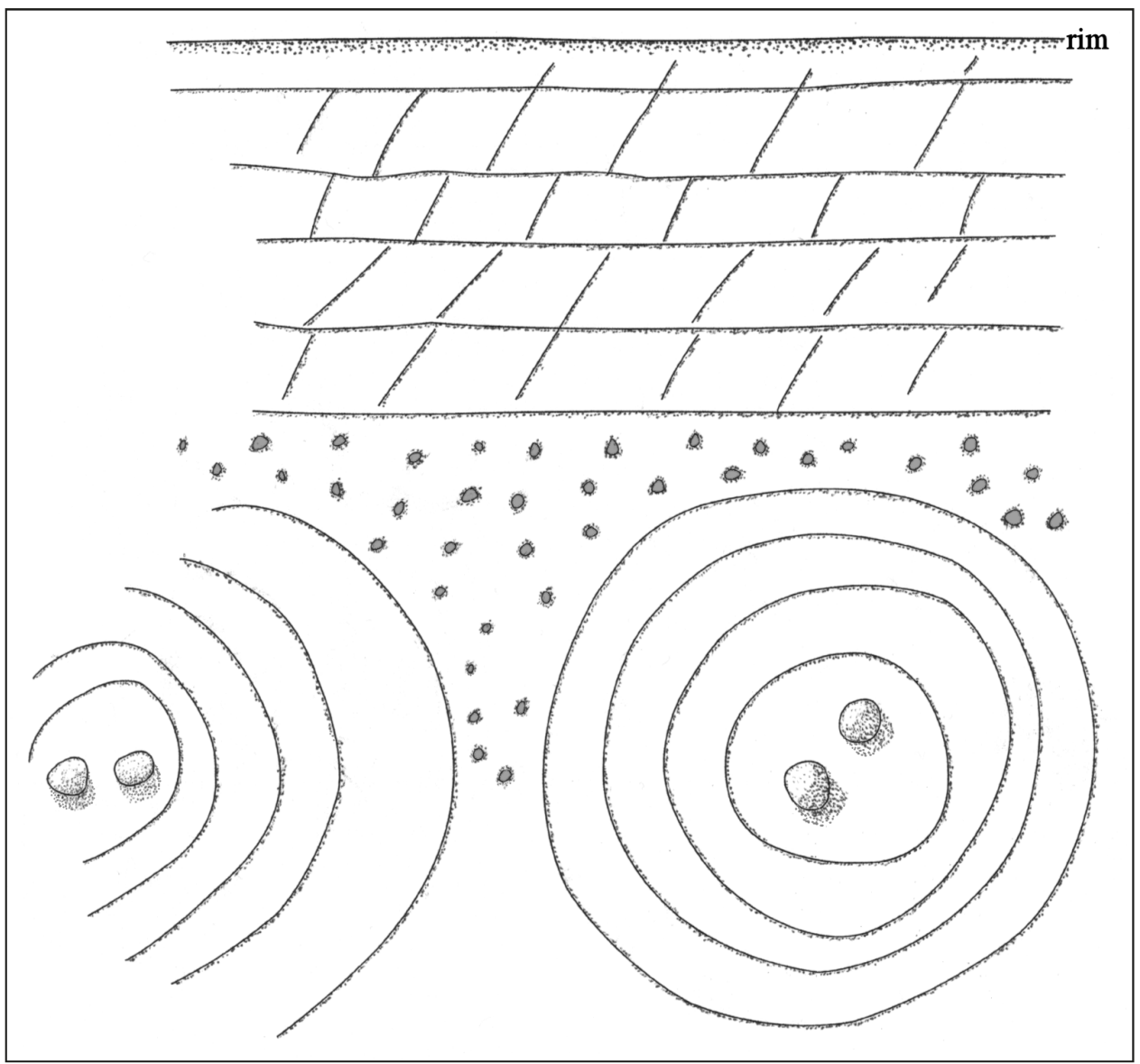

Figure 32. Foster Trailed-Incised vessel section from the Eli Moores site.

\section{Neck Banded}

The neck banded rim and body sherds $(\mathrm{n}=12)$ at the Eli Moores site are from Nash Neck Banded jars (Suhm and Jelks 1962:111), a common post-A.D. 1300 Red River Caddo utility ware. These sherds are from grog-tempered $(n=10,83$ percent), bone-tempered $(n=1,8$ percent), and shell-tempered $(n=1,8$ percent) vessels.

\section{Punctated, fingernail}

These rim $(n=4)$ and body $(n=5)$ sherds are from vessels with horizontal or opposed rows of fingernail punctates covering the rim and/or the body. They are likely from Emory Punctated-Incised jars.

\section{Punctated, tool}

Rim and body sherds with tool punctations $(n=38)$ comprise 6.9 percent of the utility wares in the Eli Moores ceramic assemblage. Rim sherds $(n=13)$ have horizontal punctated rows under the lip, at midrim, and at the rim-body juncture (see Figure 28e). Body sherds $(n=24)$ have horizontal rows as well as diagonal linear $(n=1)$ tool punctates. These sherds are likely to also be from Emory Punctated-Incised jars or other Red River Caddo utility wares that have rim punctated decorative elements, such as late varieties of Foster Trailed-Incised (see Schambach and Miller 1984) and McKinney Plain. 
Ridged

All five vertically ridged body sherds are from at least one grog-tempered Belcher Ridged, var. Belcher jar. Belcher Ridged vessels are one of the principal utility wares in Belcher phase Caddo ceramic assemblages (Kelley 2012; Webb 1959), and thus the sherds in the Eli Moores collection are likely from non-local vessels.

\section{Roughened}

The two roughened rims are from McKinney Plain jars. Suhm and Jelks (1962:97) note that McKinney Plain jar rims "are almost always roughened and bumpy and contrast with bodies when the latter are smoothed."

\section{Trailed-Incised}

The trailed-incised sherds are apparently from Foster Trailed-Incised jars that are predominantly grogtempered (Table 5). The horizontal-diagonal opposed trailed elements on the few rims (see Figures 30a and 32) are consistent with var. Dobson vessels (see Schambach and Miller 1984:121 and Figure 11-10).

Table 5. Trailed-Incised decorative elements in the Eli Moores site utility wares.

\begin{tabular}{lccc}
\hline Decorative element & Rim & Body & N \\
\hline Curvilinear trailed lines & - & $10^{*}$ & 10 \\
Diagonal opposed lines & - & 18 & 18 \\
Hatched panel & - & 1 & 1 \\
Hatched curvilinear panel & - & 1 & 1 \\
Horizontal lines & 1 & - & 1 \\
Horizontal-diagonal opposed lines & 2 & $38^{*}$ & 3 \\
Parallel trailed lines & - & 2 & 38 \\
Straight trailed line & - & 1 & 1 \\
Straight-curvilinear trailed lines & - & 1 & 1 \\
Vertical trailed lines & - & 73 & 76 \\
\hline Totals & 3 & & 2 \\
\hline
\end{tabular}

*includes sherds with shell temper

Body sherds have both straight line and curvilinear trailed-incised elements (see Figure 30b-g and Table 5). These are from a number of different vessels, and to account for the number of straight and parallel trailed elements, these sherds may include lower rim-body vessel portions.

\section{Fine Wares}

The 669 fine ware sherds in the Eli Moores ceramic assemblage are dominated by sherds from vessels with engraved and excised elements (91 percent) (Table 6), principally from Barkman Engraved and Simms Engraved vessels. The remainder of the fine wares are red-slipped (3.5 percent) and trailed (5.5 percent), from Keno Trailed bowls and bottles. 
Table 6. Decorative methods represented in the fine wares from the Eli Moores site.

\begin{tabular}{lccrr}
\hline Decorative Method & Rim & Body & $\mathrm{N}$ & $\%$ \\
\hline Engraved & 203 & 385 & 588 & 88.6 \\
Engraved-appliqued & - & 4 & 4 & 0.6 \\
Engraved-lip notched & 2 & - & 2 & 0.3 \\
Engraved-red-slipped & 2 & 10 & 12 & 1.2 \\
Engraved-red-slipped-lip notched & 1 & - & 1 & 0.2 \\
Excised punctated & 1 & 20 & 25 & 0.2 \\
Red-slipped & $5 *$ & 34 & 36 & 3.5 \\
Trailed & 2 & 453 & 669 & 100.0 \\
\hline Totals & 216 & & & 5.5 \\
\hline
\end{tabular}

*includes red-slipped effigy head on rim of bowl

\section{Engraved}

In general, post ca. A.D. 1550 Caddo fine wares in this part of the Red River basin-in the latter part of the defined Texarkana phase-include Keno Trailed, Simms Engraved, Avery Engraved, Belcher Engraved, and Hodges Engraved (Perttula 1992:126). Barkman Engraved may well be considered a preA.D. 1550 fine ware from earlier Texarkana phase contexts. This constellation of engraved and trailed fine ware types at sites such as Eli Moores, Hatchel (41BW3), Hill Farm (41BW169), and Mitchell (41BW4) suggest the principal occupation at Eli Moores and at these other Nasoni Caddo sites is contemporaneous with the latest Belcher phase (Belcher IV) occupation at the Belcher site, and at the late 17th century to early 18th century component at the Chakanina phase Cedar Grove site (3LA97) in southwest Arkansas (see Webb 1959; Schambach and Miller 1984; Kelley 2012).

Sherds from Simms Engraved and Barkman Engraved vessels dominate the fine wares from the Eli Moores site (Table 7). They account for about 58 percent of all the fine ware rims (see Table 6) and ca. 30 percent of the body sherds (in actuality many of these are lower rim/body sherds missing the vessel lip, as the Simms Engraved or Barkman Engraved vessels are decorated only on the carinated rim panel). Other identified fine ware engraved ceramic types in the assemblage include Avery Engraved, Belcher Engraved, Natchitoches Engraved, Hodges Engraved, Hatchel Engraved, Taylor Engraved, and Glassell Engraved. It is suspected that only the Barkman Engraved, Hatchel Engraved, and Simms Engraved fine wares were produced locally by Red River Caddo potters, but the other defined ceramic types were likely produced by contemporaneous Great Bend Belcher phase Caddo potters living downstream along the Red River and its major tributaries.

Table 7. Identified fine ware engraved ceramic types in the carinated bowls from the Eli Moores ceramic assemblage.

\begin{tabular}{lcccr}
\hline Ceramic Type & Rim & Lower Rim & Body & N \\
\hline Simms Engraved & 92 & 50 & 28 & 170 \\
Barkman Engraved & 25 & 9 & 46 & 80 \\
Belcher Engraved & - & 2 & 1 & 3 \\
Avery Engraved & 1 & 1 & - & 2
\end{tabular}


Table 7. Identified fine ware engraved ceramic types in the carinated bowls from the Eli Moores ceramic assemblage, cont.

\begin{tabular}{lcccc}
\hline Ceramic Type & Rim & Lower Rim & Body & N \\
\hline Natchitoches Engraved & - & - & 2 & 2 \\
Glassell Engraved & - & 1 & - & 1 \\
Hatchel Engraved* & - & - & 1 & 1 \\
Hodges Engraved & - & - & - & 1 \\
Taylor Engraved & 1 & 63 & 79 & 261 \\
\hline Totals & 119 & - & 79 \\
\hline
\end{tabular}

*bottle sherd

Sherds from Simms Engraved vessels, both grog-, bone-, and shell-tempered, are from carinated bowls, usually with narrow rim panels that bend "inward sharply, at times almost at a right angle... and the lip turns upward or outward at a right angle to the rim" (Suhm and Jelks 1962:141). Many of the rims in the Eli Moores fine wares are the later hubcap form (Form B) of Simms Engraved (see Suhm and Jelks 1962;Plate 71b; Skinner et al. 1969:42 and Figures 16c-d and 21a, c; Perttula 1992:131). Decorations on the rims include horizontal panels with ticked lines or simply horizontal lines encircling the vessel; with tick marks on one or more lines; a row of tick marks at the carination; mid-panel excised punctations; excised, hatched, and cross-hatched brackets or single vertical lines that divide the panels; hatched pendant triangles; cross-hatched triangle elements; and sets of closely-spaced vertical or near vertical engraved lines (Figures 33a-e and 34a-1). White $(n=5)$ and red $(n=3)$ clay pigments (4.7 percent of the Simms Engraved sherds) are sometimes rubbed in the engraved designs; and lips are occasionally notched ( $\mathrm{n}=5$, 5.4 percent of the rims). The similarities in design element structure and design elements between Simms Engraved and Barkman Engraved (i.e., narrow horizontal bands with a row of excised punctates), and the generally younger (ca. post-A.D. 1600) age of Simms Engraved vessels from other Red River contexts suggests that Simms Engraved is a stylistically linked evolution from later versions of Barkman Engraved fine wares in this part of the Red River basin.

The Barkman Engraved sherds from the Eli Moores site (Figure 35a-f and Figure 36a-i) are distinctive because they have multiple horizontal and curvilinear hatched or cross-hatched bands on the rim panel of carinated bowls as well as upper horizontal lines, along with horizontal rows of excised punctates mid-line in other open rectangular and/or curvilinear/near-vertical panels and sometimes in a row at the vessel carination (see Suhm and Jelks 1962:7 and Plate 4). One lower rim sherd has a rectilinear panel with attached small excised triangles on the outside edges of the panel. Specific motifs are typically repeated four times around the rim panel. One body sherd included in with the remainder of the Barkman Engraved sherds from the Eli Moores site has a concentric circle element and an adjacent zone with at least one row of excised punctates. A white $(n=12)$ pigment is also occasionally rubbed in the engraved design on these vessels (15.0 percent of the Barkman Engraved sherds).

The Avery Engraved sherds have sets of concentric semi-circle decorative elements on the rim panel of carinated bowls and compound bowls (Figure 37a). The lower rim panel of the compound bowl has an arc of concentric semi-circles divided by triangular and cross-hatched brackets.

The one confidently identified Hatchel Engraved sherd in the Eli Moores fine wares is a bottle vessel section with white pigment rubbed in the engraved lines. The decorative element consists of oval-shaped 


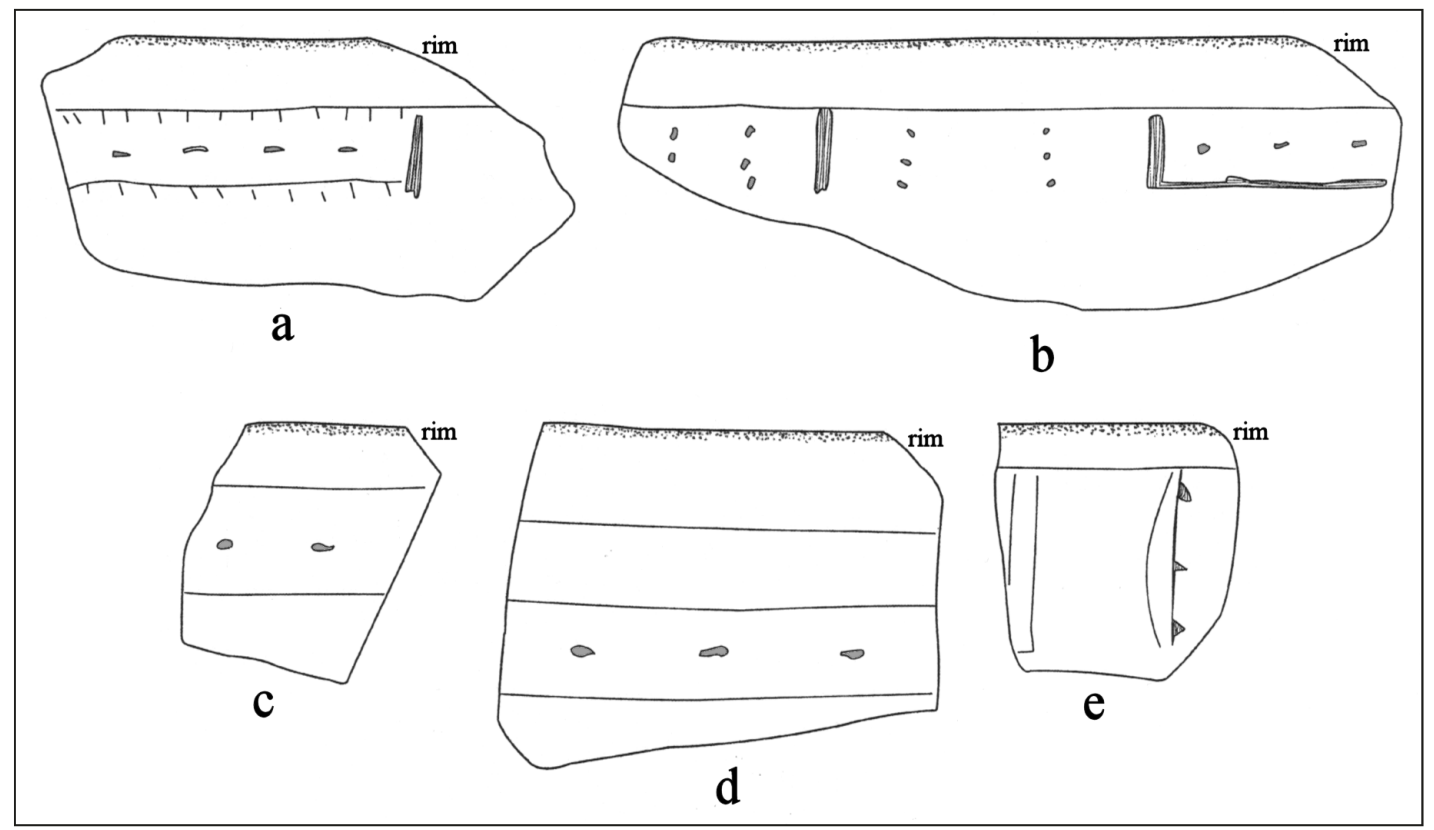

Figure 33. Decorative elements on Simms Engraved rim sherds.

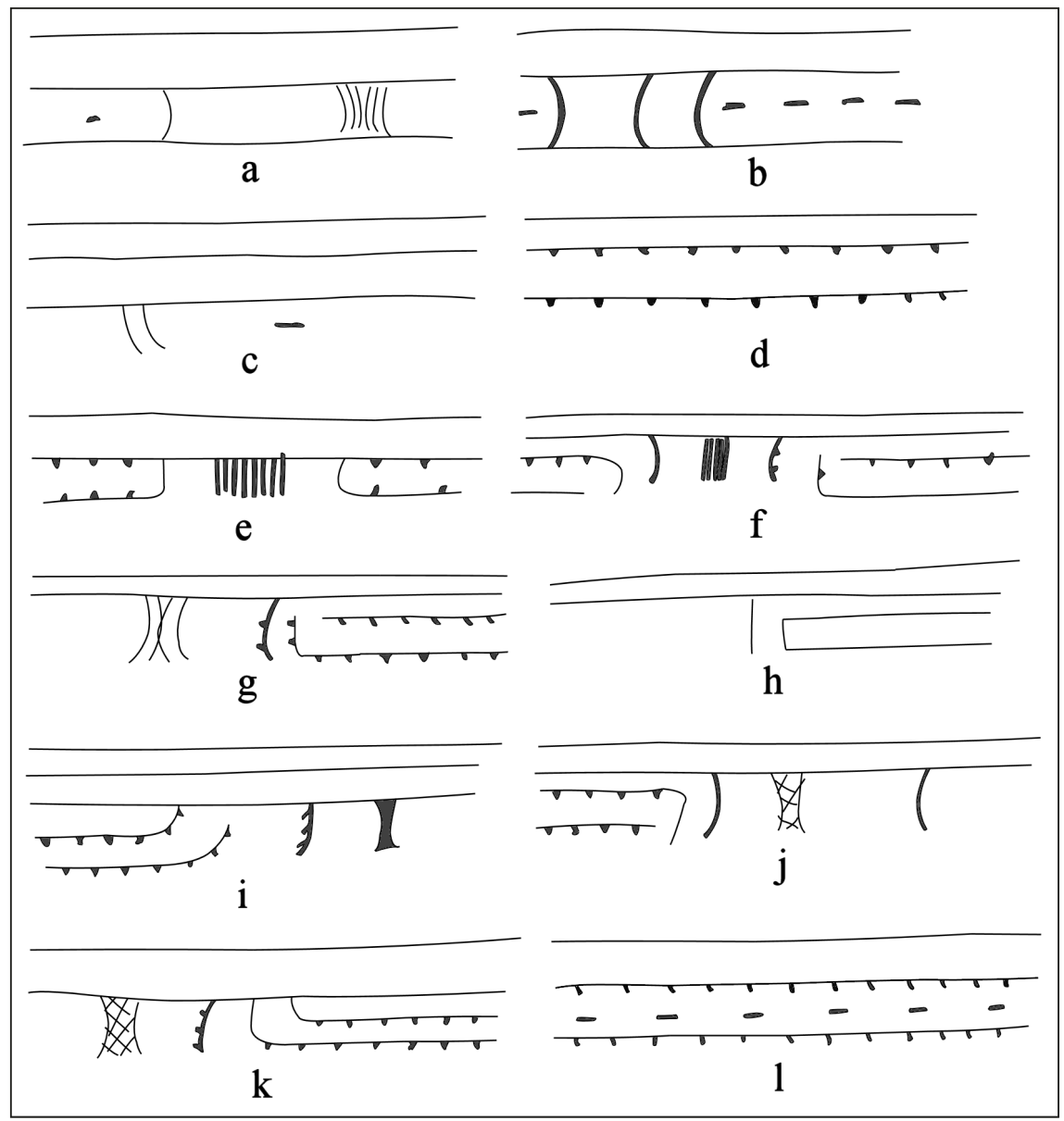

Figure 34. Different engraved decorative elements on Simms Engraved rim panels. 

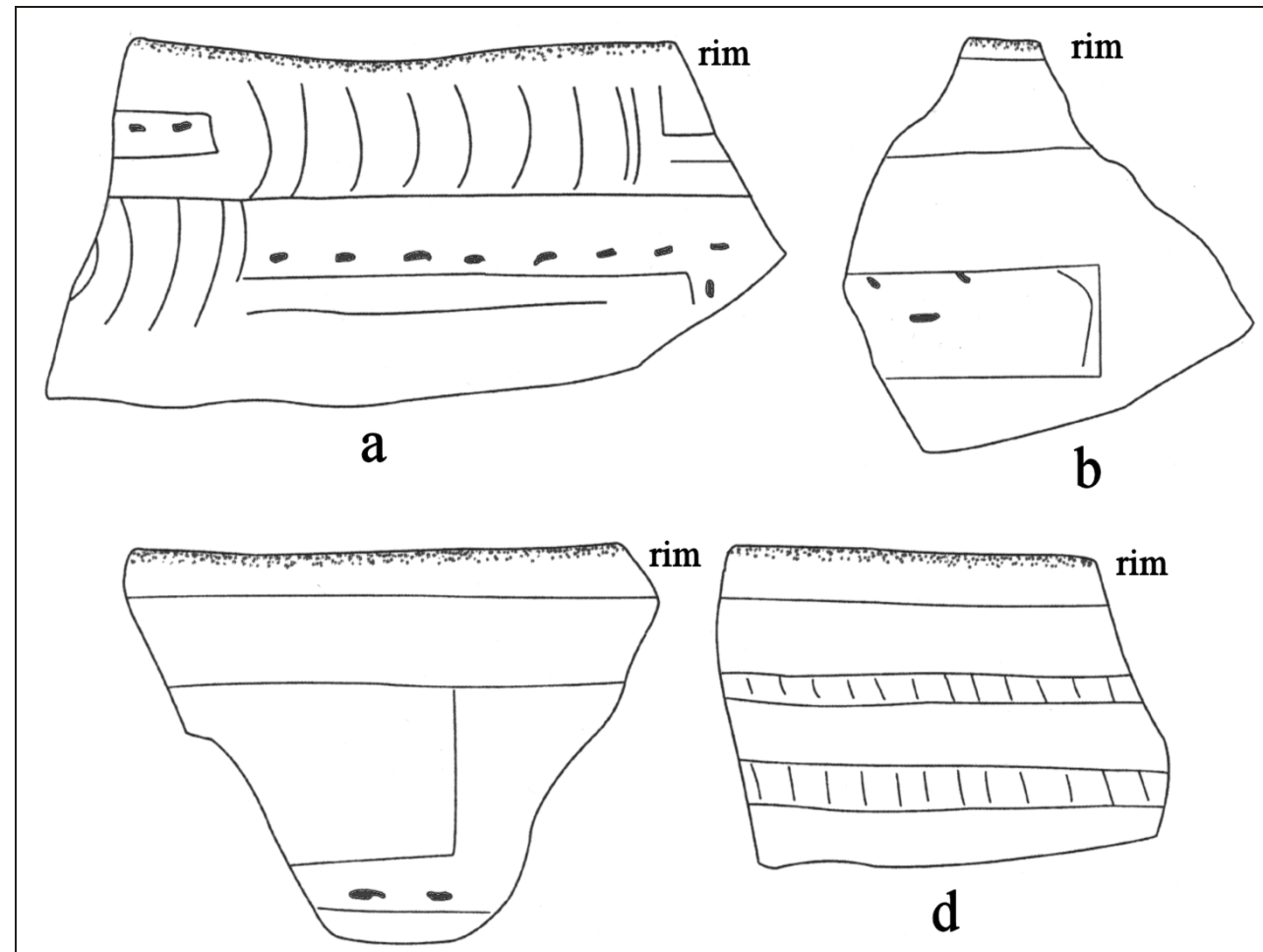

C

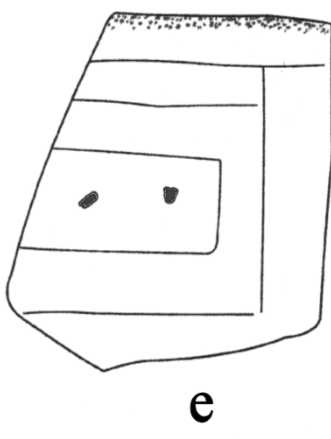

rim

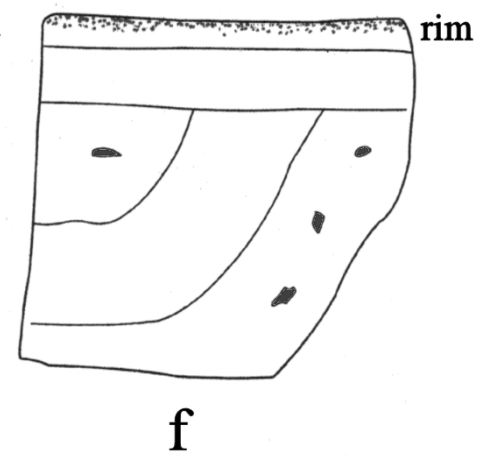

Figure 35. Decorative elements on Barkman Engraved rim sherds.

panels filled with curvilinear arcing lines in the same or opposed directions. Two of the arcing lines have short slanting tick marks (Figure 38).

Possible Hodges Engraved vessels, from carinated bowls and compound bowls, include rim and body sherds ( $n=9)$ with narrow to wide cross-hatched zones, negative ovals/circles, curvilinear lines, and/or curvilinear lines and circular elements with tick marks or hatched pendant triangles on them (Figure 39bh). Two of these sherds have an exterior red slip.

The two Natchitoches Engraved sherds from the Eli Moores site are from a shell-tempered bowl with small ticked curvilinear lines between hatched triangle elements and narrow diagonal hatched zones (see Figure 39a). The bowl has a collared rim (cf. Schambach and Miller 1984:Figure 11-11). A third possible Natchitoches Engraved or Hodges Engraved sherd is from a carinated bowl; the decorative element consists of a triangle with a hatched apex and small tick marks. 


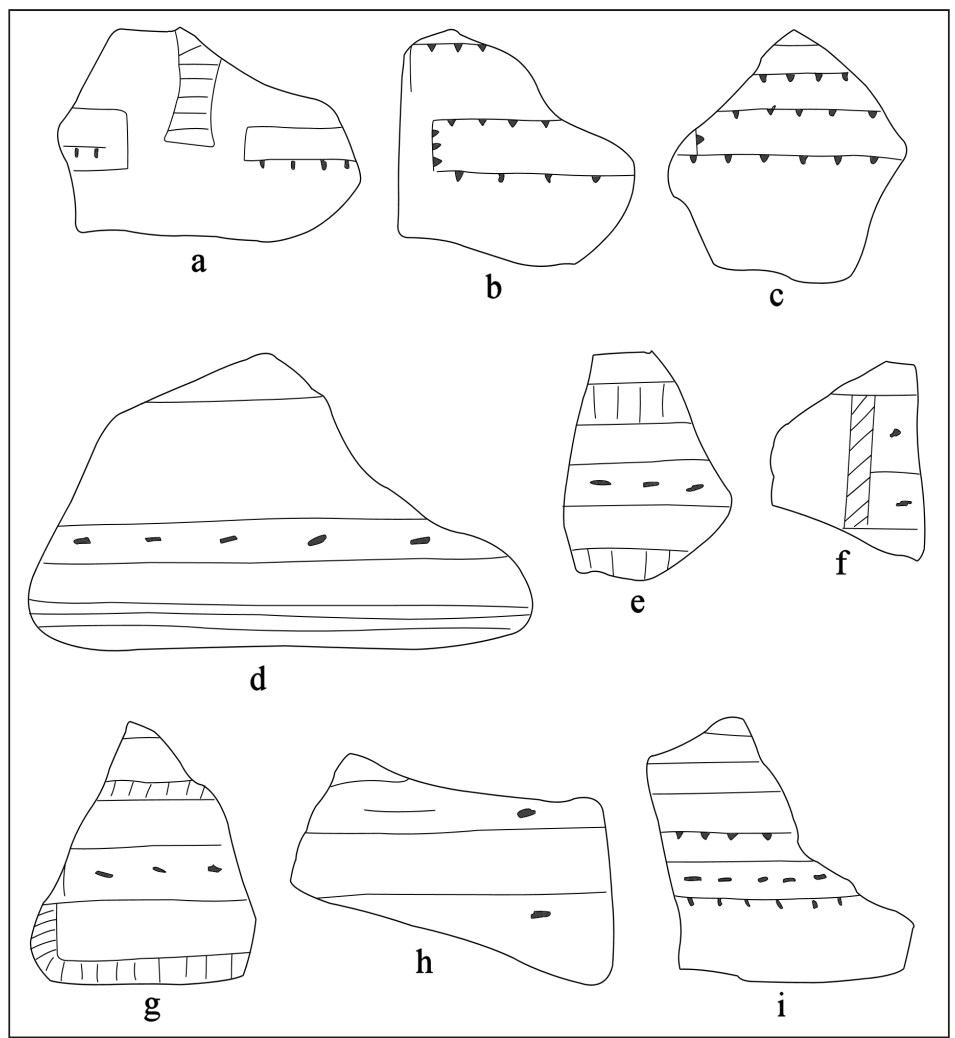

Figure 36. Decorative elements on Barkman Engraved lower rim sherds from carinated bowls.

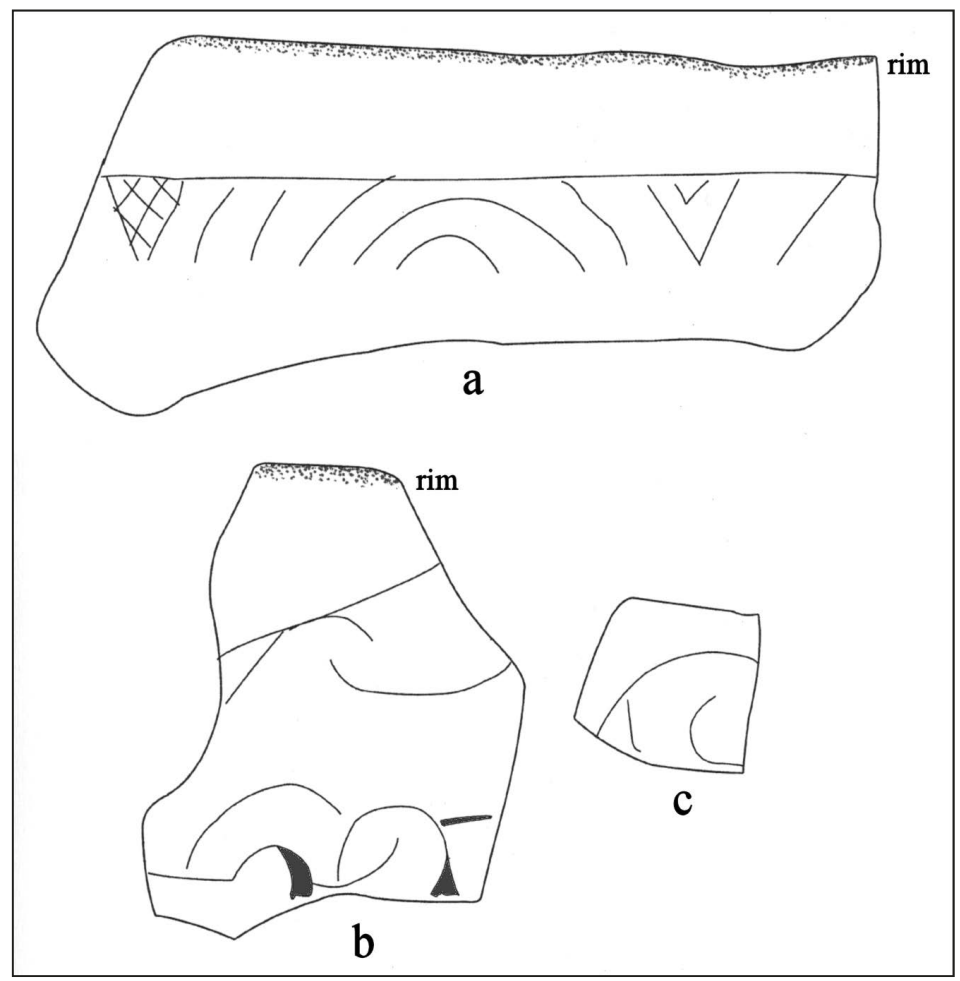

Figure 37. Avery Engraved and Taylor Engraved sherds: a, Avery Engraved compound bowl; b-c, Taylor Engraved. 


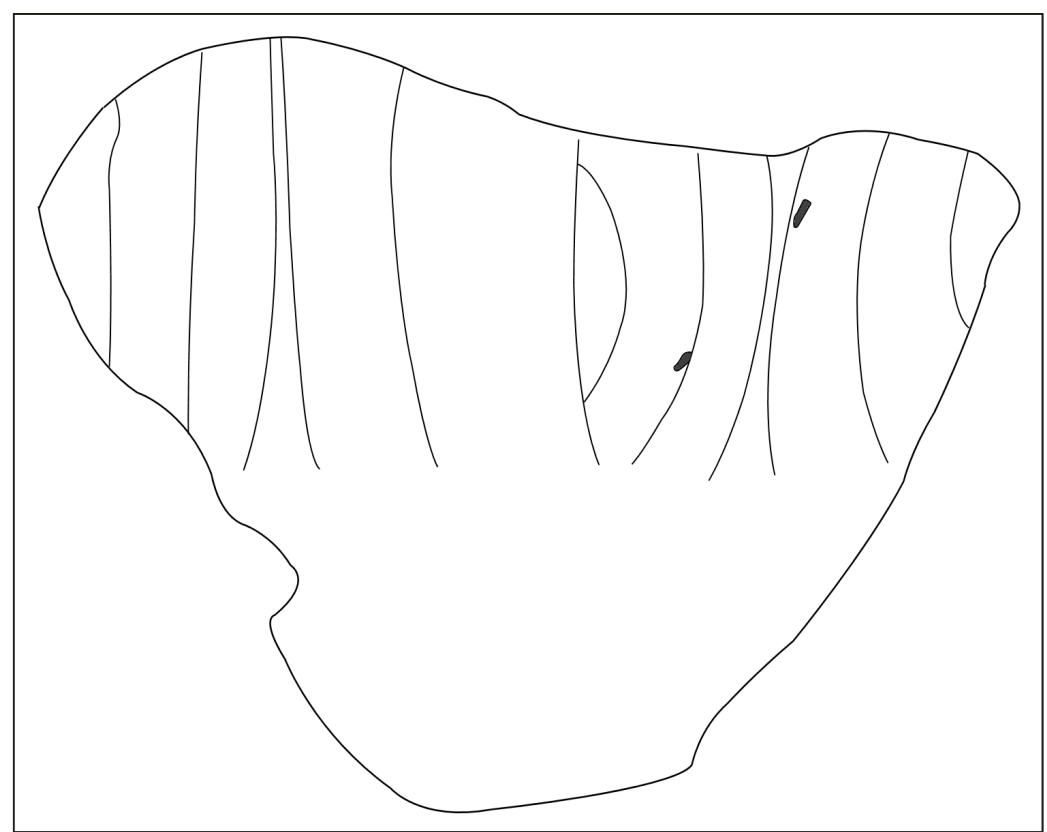

Figure 38. Hatchel Engraved bottle sherd.

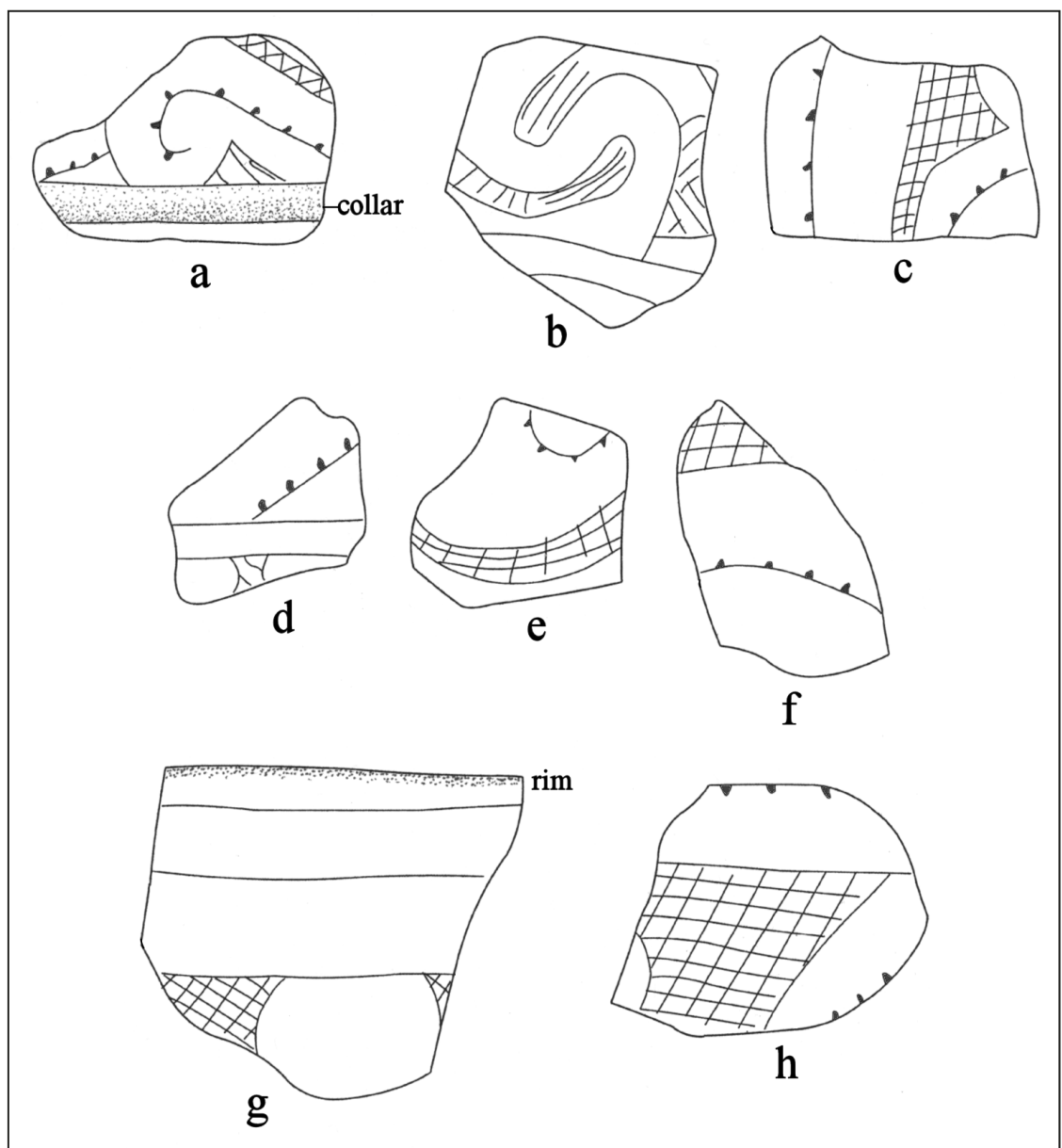

Figure 39. Hodges Engraved and Natchitoches Engraved decorative elements on sherds. 
The one identified Taylor Engraved sherd in the assemblage is a grog-tempered rim sherd with a series of hooked arm elements and curved lines on diagonal as well as horizontal lines (see Figure 37b). A red pigment has been rubbed in the engraved design. A second possible Taylor Engraved rim sherd has a portion of a circular zone with a hooked arm element (see Figure 37c).

Another distinctive category of engraved fine wares have scroll elements and hatched scroll fill elements as well as hatched or excised bracket dividers (Figure 40a-j). This includes 19 rim sherds with horizontal or slanting scroll elements, 10 lower rim sherds from carinated bowls, one of which is shelltempered, and 16 body sherds, three of which are bone-tempered; one rim has a red pigment rubbed in the engraved lines. Most of these sherds have either horizontal scroll bands, or slanting scrolls, with upper and lower scroll fill zones with open or cross-hatched triangle elements. One rim has a horizontal scroll band with vertical lines and triangle elements within it (Figure 40h). Another two of these sherds have negative ovals in the scroll fill zones created by excised brackets (Figure 40c-d), and they may be from Glassell Engraved or Hodges Engraved carinated bowls, although the scroll lines lacks tick marks, a common feature of Hodges Engraved carinated bowls (see Schambach and Miller 1984:Figures 11-15a-b and 11-34a). One compound bowl sherd has widely-spaced horizontal engraved lines on the upper panel and a cross-hatched scroll fill zone on portions of the lower rim panel (Figure 40b).

There are other distinctive rim and body sherds, and one vessel section, from carinated bowls ( $\mathrm{n}=$ one vessel section and two other rim sherds) and bottles $(n=1)$ with scroll elements and associated central circles and broad cross-hatched scroll fill zones. Some of the rims have an upper set of horizontal engraved lines and a scroll panel with concentric circles and attached rectilinear or triangular cross-hatched bands (Figure 41a-c; see also Figure 40a); white pigment has been occasionally rubbed in the engraved lines. These are likely from Glassell Engraved vessels (see Schambach and Miller 1984:Figure 11-6).

There is a wide variety of engraved rim and body sherds with more basic and indeterminate decorative elements that cannot be confidently associated with defined Red River Caddo fine ware pottery types. These decorative elements are listed in Table 8. Most of these sherds feature simple straight line and geometric elements, but 15 percent have curvilinear or circle elements.

There are 81 bottle body sherds in the Eli Moores fine ware assemblage that have engraved elements (ca. 14 percent of the engraved sherds, see Table 6); three sherds have a red pigment rubbed in the engraved lines. At least nine of the sherds are from Hodges Engraved vessels (see Figure 39b-f): eight sherd with curvilinear lines with ticked marks as well as curvilinear cross-hatched or hatched zones (including three from shell-tempered vessels with interior/exterior red slipped surfaces), and another with hatched hooked arms. The other body sherds from bottles (Figure 42a-h) include the following decorative elements:

- $\quad$ straight to curvilinear lines with hatched or excised pendant triangles ( $\mathrm{n}=2$ sherds, Figure $42 \mathrm{~d}, \mathrm{f}$ );

- curvilinear lines ( $\mathrm{n}=26$ sherds);

- curvilinear lines, one with small tick marks ( $n=1$ sherd, probable Hodges Engraved)

- broad curvilinear lines with large excised tick marks ( $n=2$ sherds, Figure 42a)

- curvilinear lines and circular elements ( $n=2$ sherds)

- curvilinear lines with set of large pendant triangles with inner negative ovals ( $n=6$ sherds, Figure 42g)

- $\quad$ straight line ( $\mathrm{n}=9$ sherds);

- $\quad$ parallel lines ( $\mathrm{n}=7$ sherds);

- curvilinear and horizontal lines ( $n=2$ sherds, one with shell temper);

- triangular elements ( $\mathrm{n}=3$ sherds);

- curvilinear and diagonal lines ( $\mathrm{n}=2$ sherds); 

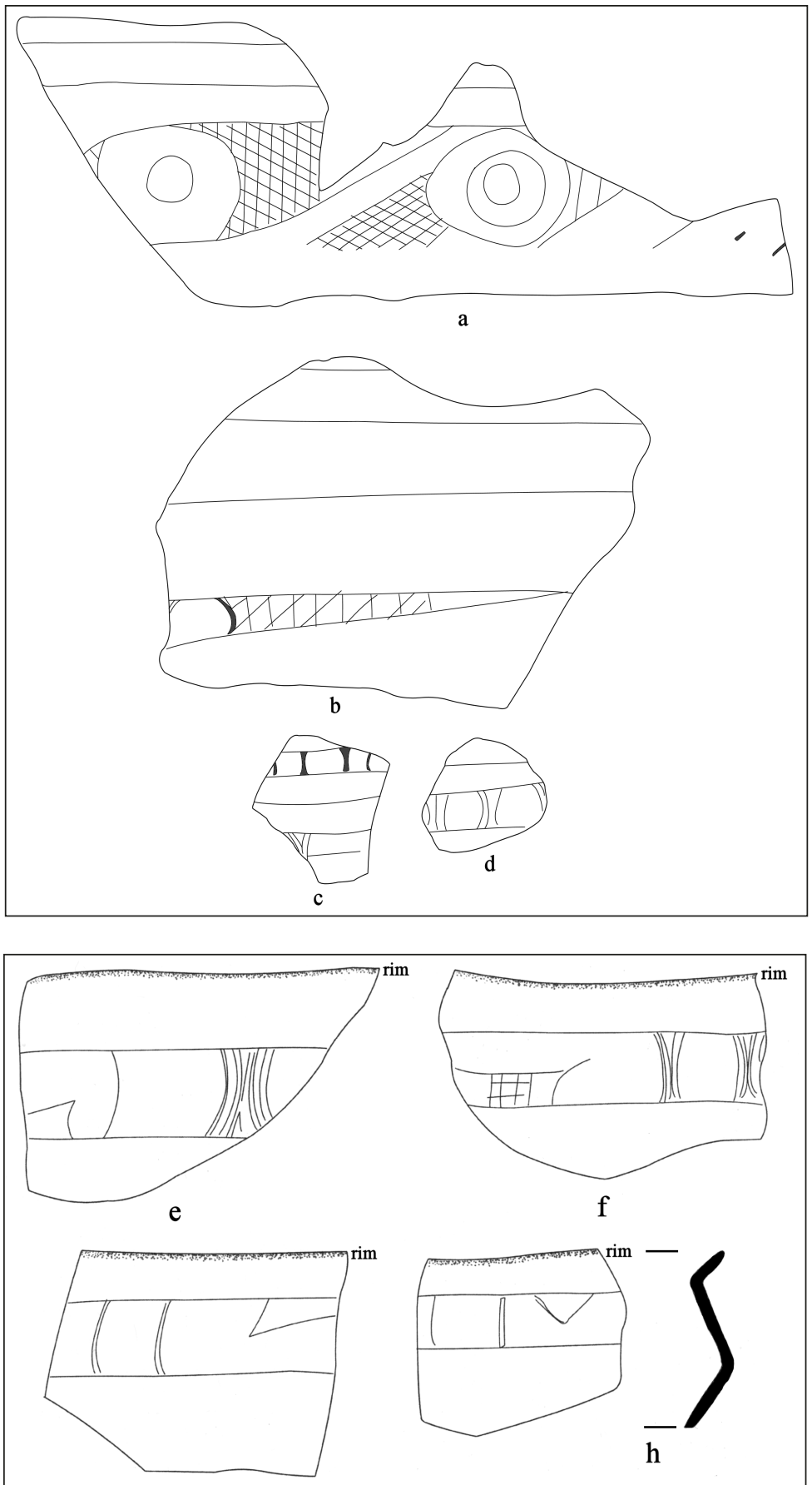

g
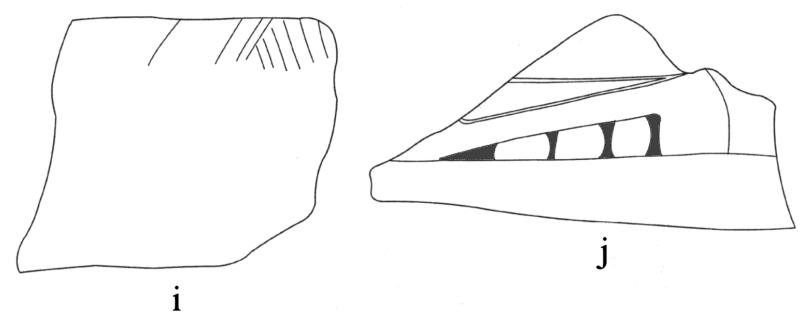

Figure 40. Rim and body sherds from the Eli Moores site with engraved scroll elements. 

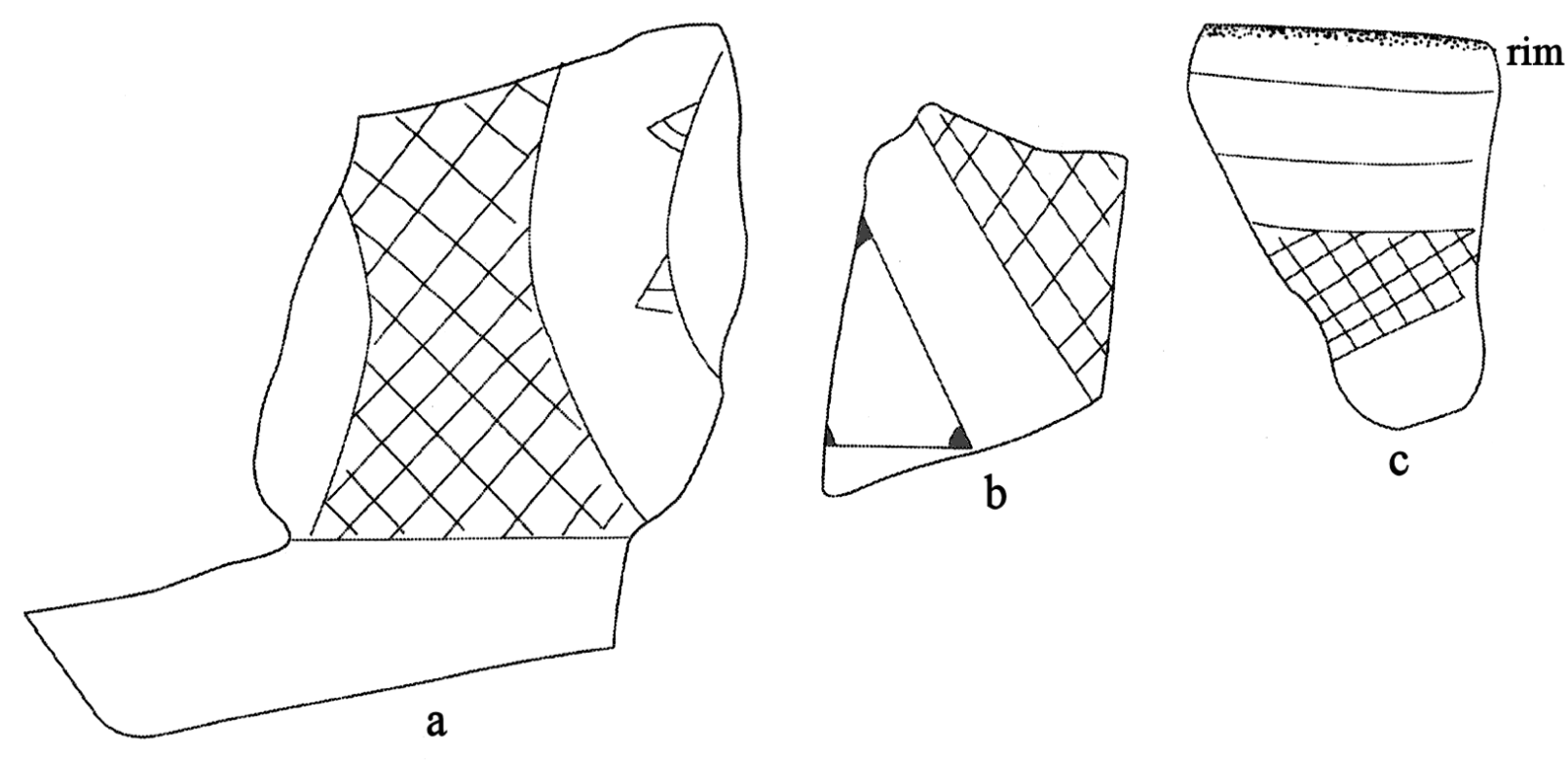

Figure 41. Rim and body sherds with scroll elements and broad cross-hatched engraved zones.

Table 8. Indeterminate engraved rim and body sherds in the Eli Moores site fine wares.

\begin{tabular}{|c|c|c|c|}
\hline Decorative element & $\operatorname{Rim}$ & Body & $\mathrm{N}$ \\
\hline Straight line & - & 38 & 38 \\
\hline Horizontal lines & 33 & 1 & 34 \\
\hline Parallel lines & - & 29 & 29 \\
\hline Curvilinear lines & - & 9 & 9 \\
\hline Horizontal and diagonal lines & 3 & 2 & 5 \\
\hline Diagonal and curvilinear lines & - & 5 & 5 \\
\hline Hatched triangle & 2 & 2 & 4 \\
\hline Horizontal and vertical lines & 1 & 2 & 3 \\
\hline Cross-hatched zone & - & 3 & 3 \\
\hline Horizontal lines and curvilinear-diagonal lines & - & 3 & 3 \\
\hline Cross-hatched triangles & 2 & - & 2 \\
\hline Horizontal excised zone & - & 2 & 2 \\
\hline Horizontal lines and associated circle elements & 2 & - & 2 \\
\hline Concentric circle element & - & 2 & 2 \\
\hline Straight line with small tick marks & - & 1 & 1 \\
\hline $\begin{array}{l}\text { Straight line and associated circle element with excised } \\
\text { pendant triangles }\end{array}$ & - & 1 & 1 \\
\hline Horizontal lines and excised pendant triangles & 1 & - & 1 \\
\hline Horizontal lines and curvilinear line with tick marks & - & 1 & 1 \\
\hline $\begin{array}{l}\text { Horizontal lines on upper panel, cross-hatched zone on } \\
\text { lower panel }\end{array}$ & - & 1 & 1 \\
\hline Diagonal lines & - & 1 & 1 \\
\hline Hatched band & - & 1 & 1 \\
\hline Opposed lines & - & 1 & 1 \\
\hline Totals & 44 & 105 & 149 \\
\hline
\end{tabular}


- horizontal lines ( $\mathrm{n}=1$ sherd);

- opposed lines ( $\mathrm{n}=2$ sherds);

- curvilinear cross-hatched zones and concentric circle element ( $n=1$ sherd, Figure $42 \mathrm{~h}$ );

- and curvilinear and hatched lines ( $\mathrm{n}=5$ sherd; three have a red pigment).

These other sherds may mostly be from Hatchel Engraved bottles (cf. Suhm and Jelks 1962:Plate 34). However, the sherds with triangle elements and/or large and small ticked lines, and the engravedappliqued body sherd, are not identified to a defined Caddo ceramic type.

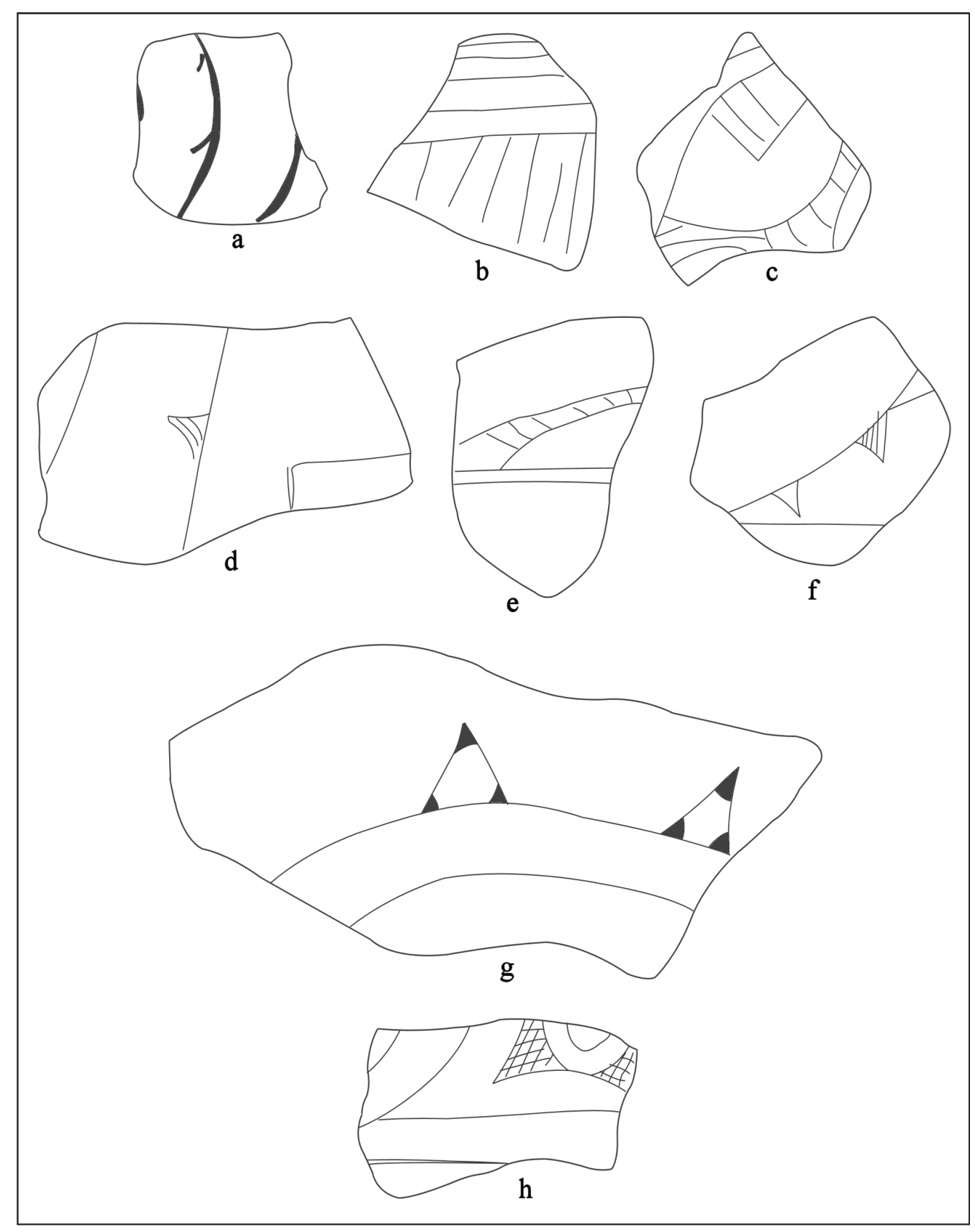

Figure 42. Decorative elements on engraved bottle sherds at the Eli Moores site. 


\section{Engraved-appliqued}

Three engraved-appliqued sherds are from Belcher Engraved, var. Belcher (see Schambach and Miller 1984:120) carinated bowls. The first sherd has two rows of small appliqued nodes below several diagonal engraved lines (Figure 43c). Two other sherds from the same vessel have a set of three short vertical engraved lines adjacent to a small appliqued knob, as well as a triangular-shaped zone filled with two rows of small excised punctations (Figure 43b).

Another engraved-appliqued sherd (part of a vessel section with 13 sherds) is from a grog-tempered vessel with concentric circles. At the center of the concentric circles are large appliqued knobs (see Figure 43a); the engraved lines have a white pigment rubbed into the engraved lines.

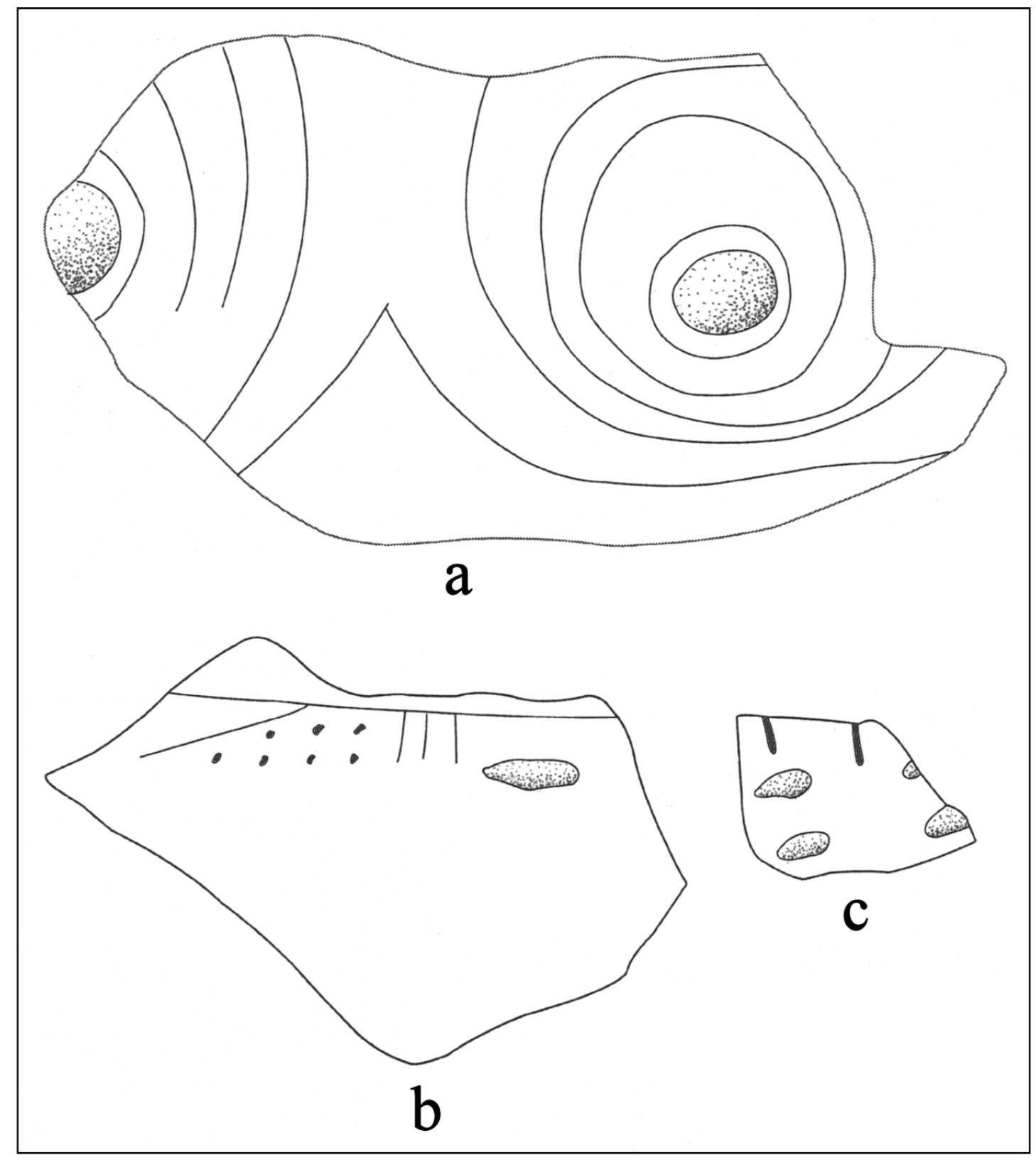

Figure 43. Engraved-appliqued sherds: a, Engraved-appliqued vessel section; b-c, Belcher Engraved. 


\section{Engraved-lip notched}

Two rim sherds have lip notching as well as engraved decorative elements. One simply has a series of horizontal engraved lines, and is probably from a bowl. The other has both sets of horizontal and opposed vertical engraved lines; it also has an interior/exterior red slip.

\section{Engraved-red-slipped}

The less distinctive of the engraved sherds with a red slip include one rim and three body sherds. The rim has a set of horizontal engraved lines, and is likely from a bowl, perhaps an effigy bowl. The three body sherds have horizontal, parallel, or straight line elements. One Barkman Engraved body sherd, from a shell-tempered vessel, also has an interior/exterior red slip, as does a Simms Engraved rim with a horizontal panel filled with sets of very closely-spaced vertical lines.

\section{Engraved-red-slipped-lip notched}

This rim, probably from a bowl, has both horizontal and vertical engraved lines on it, and it has been red-slipped on both interior and exterior vessel surfaces. It is also lip notched.

\section{Excised punctated}

This sherd is a rim with a single row of excised punctations on the vessel lip.

\section{Red-slipped}

The 25 red-slipped sherds in the Eli Moores fine wares are from both grog-tempered $(n=19)$ and shell-tempered $(n=6)$ vessels. The latter may be from the undecorated portions of shell-tempered Avery Engraved vessels made by McCurtain phase Caddo peoples living upstream from the Eli Moores site on the Red River, or from Clement Redware vessels made by the same potters (see Flynn 1976).

All five rim sherds have a red slip on both interior and exterior surfaces. This includes a bowl sherd with an attached effigy head (Figure 44) and a rim from a compound bowl. Body sherds primarily have a red slip on both vessel surfaces ( 68 percent of 25 body sherds); 28 percent have a red slip only on their exterior surface, and 4 percent have a red slip only on its interior surface.

\section{Trailed}

The trailed fine ware sherds are from Keno Trailed bowls $(n=30)$ and bottles $(n=6)$ (see Table 6). The bowls have horizontal and curvilinear elements on the rim portion of the vessel as well as multiple curvilinear trailed lines covering the vessel body (Figure 45a-c); one bowl sherd is from a shell-tempered vessel. Keno Trailed bottle sherds have curvilinear, multiple curvilinear, and diagonal opposed and curvilinear trailed lines on the vessel body (Figure 46a-c). These sherds may be from Keno Trailed, var. McClendon vessels (see Schambach and Miller 1984:Figure 11-41a).

\section{Plain Base Sherds}

There are 68 plain base sherds in the ceramic assemblage. They are flat and disk-shape bases that were apparently made separately from, and then attached to, the remainder of the vessel as it was being 


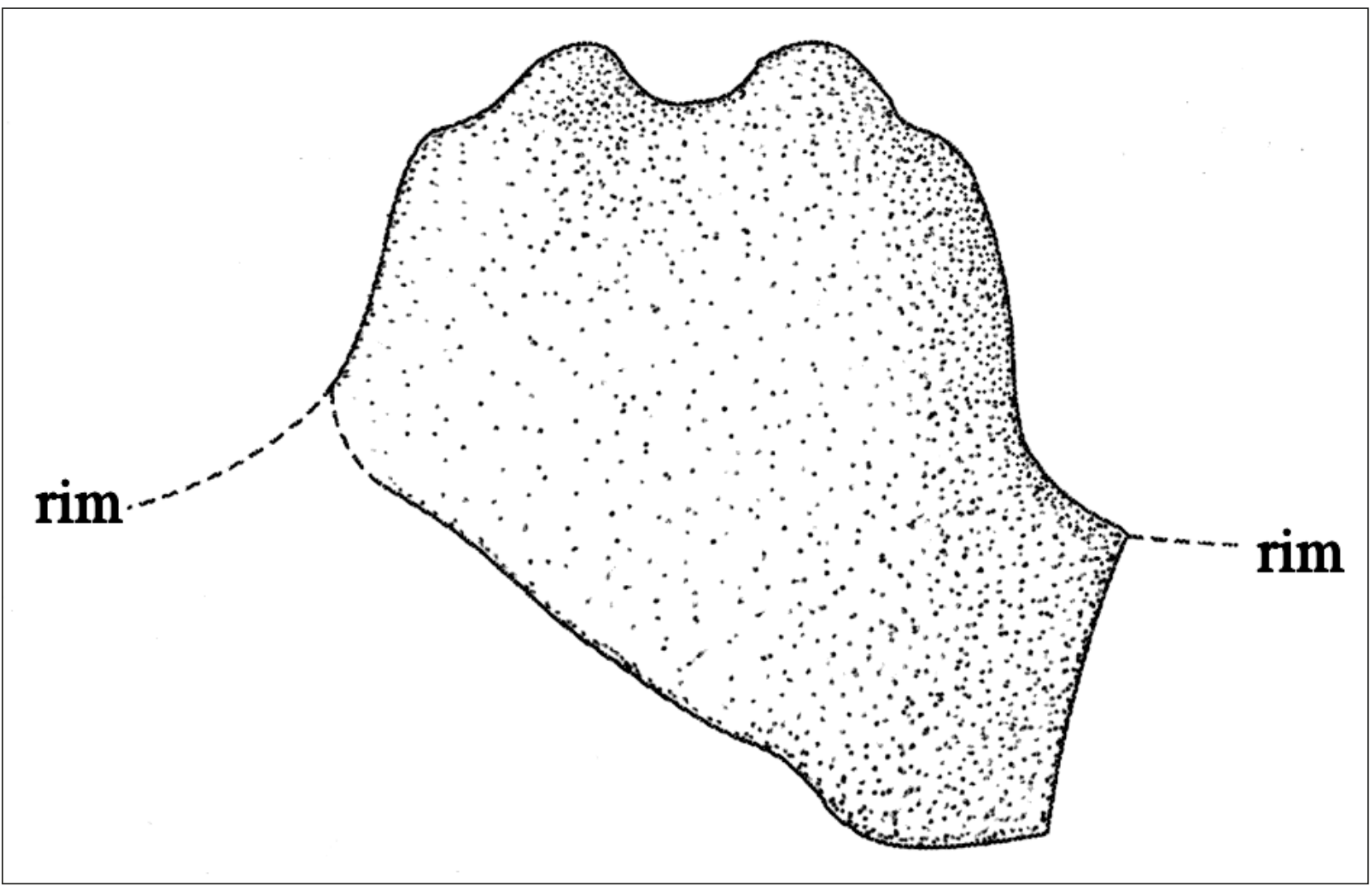

Figure 44. Red-slipped effigy head sherd.

built up from coils. Approximately 16.2 percent of the bases are from bone-tempered vessels and 4.4 percent are from shell-tempered vessels; the remainder are from grog-tempered vessels.

\section{Spindle Whorls}

There are 17 plain spindle whorls in the Eli Moores ceramic assemblage, including one found in the fill of Burial J-1, and an 18th that is from a Foster Trailed-Incised body sherd. Spindle whorls are diskshaped sherds (usually base sherds) that have a central perforation or hole drilled in them (Figure 47a-c). These perforations range from as small as $8.0 \mathrm{~mm}$ in diameter to as much as $17.8 \mathrm{~mm}$, with a mean perforation diameter of $13.2 \mathrm{~mm}$.

The spindle whorl would have been affixed on a spindle to help maintain its rotary motion during spinning activities. The presence of spindle whorls at the site suggests that Caddo women were processing fibers to produce textiles (cf. Alt 1999). Materials that could have been used include animal hair and various vegetable fibers, among them hemp, slippery elm, mulberry, milkweed, and nettle, as well as the bark of trees. Approximately 11.8 percent of the spindle whorls are from bone-tempered vessels.

\section{Ceramic Pipes}

One of the clay pipes (Lot 56) is an elbow pipe with a rounded shoulder, and knobs on either side of the lower pipe bowl (Figure 48). This pipe is $36.0 \mathrm{~mm}$ in height and $47.0 \mathrm{~mm}$ in length. The orifice diameter of the bowl is $37.0 \mathrm{~mm}$, and the stem has a $21.0 \mathrm{~mm}$ diameter opening. A similar elbow pipe with knobs on both its upper and lower bowl (Lot 13) is grog-tempered, with a $20.0 \mathrm{~mm}$ bowl height, a length of $49.0 \mathrm{~mm}$, and an orifice diameter of $34.5 \mathrm{~mm}$ for the bowl. The stem has a $19.5 \mathrm{~mm}$ diameter (Figure 49a). 


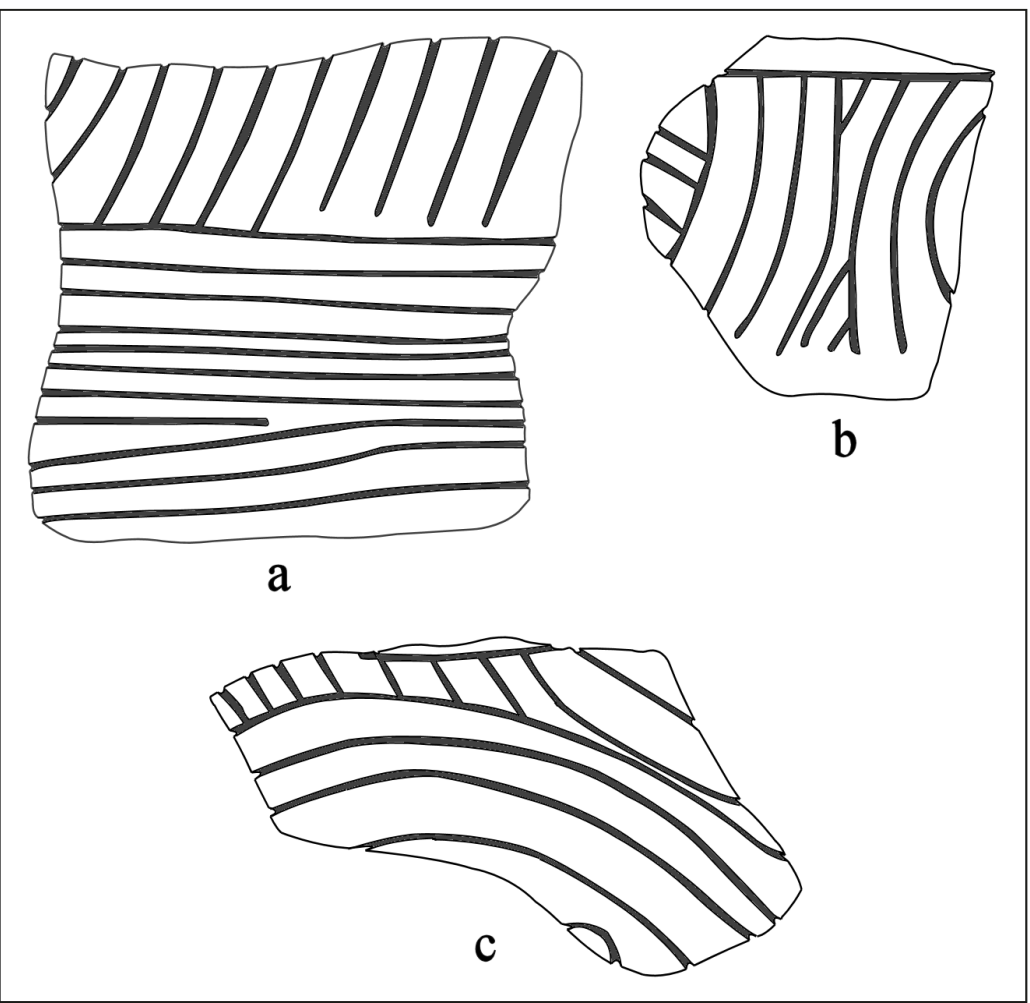

Figure 45. Keno Trailed bowl sherds.

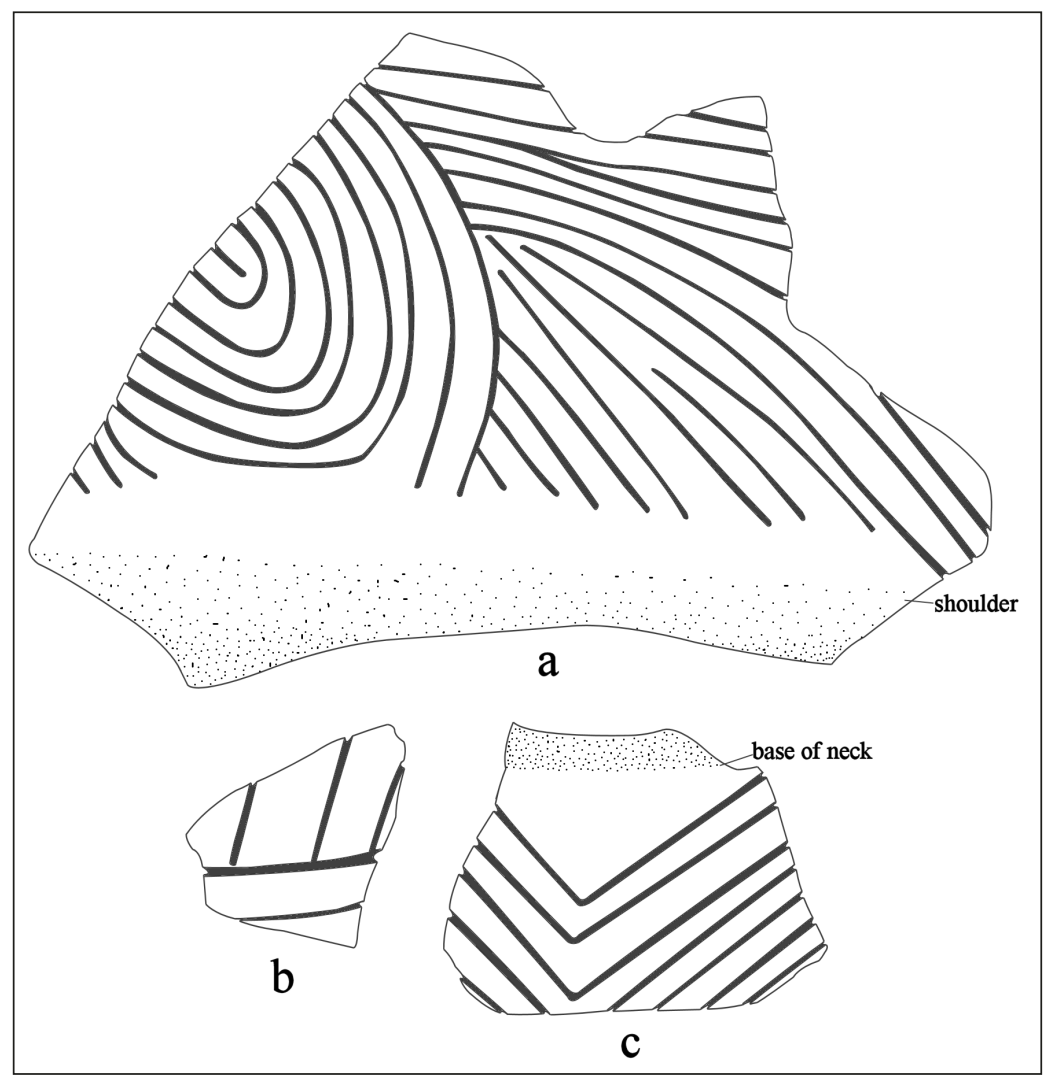

Figure 46. Keno Trailed bottle sherds. 


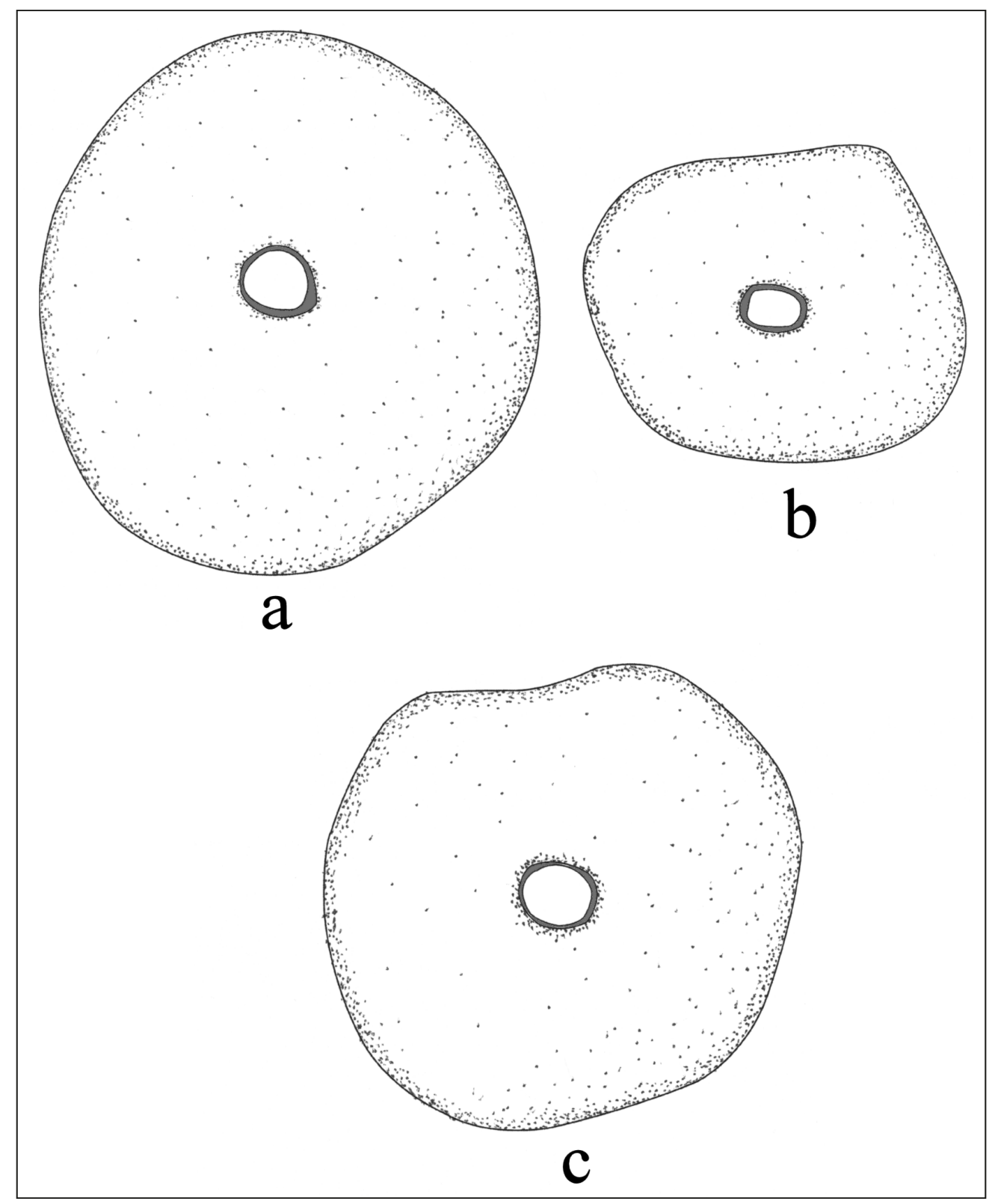

Figure 47. Plain spindle whorls from the Eli Moores site.

A third pipe is a thick tubular form (Lot 51), at least $79.5 \mathrm{~mm}$ in length. The diameter of the tube is $28.0 \mathrm{~mm}$, and the stem orifice opening is $13.0 \mathrm{~mm}$ (see Figure 49c). Perhaps the most distinctive of the ceramic pipes from the Eli Moores site has a triangular shape (see Figure 49b), with a bowl at the top with a $21.0 \mathrm{~mm}$ diameter, and the stem opening, through a slightly raised platform, only $2.0 \mathrm{~mm}$ in diameter. This pipe is $50.0 \mathrm{~mm}$ in diameter and $34 \mathrm{~mm}$ in width on any one side.

There are also single examples of elbow pipe and pre-A.D. 1450 Red River long-stemmed stem sherds in the collection, both grog-tempered. The Red River long-stemmed sherd has an $11.5 \mathrm{~mm}$ exterior diameter and a $4.2 \mathrm{~mm}$ diameter stem opening. 


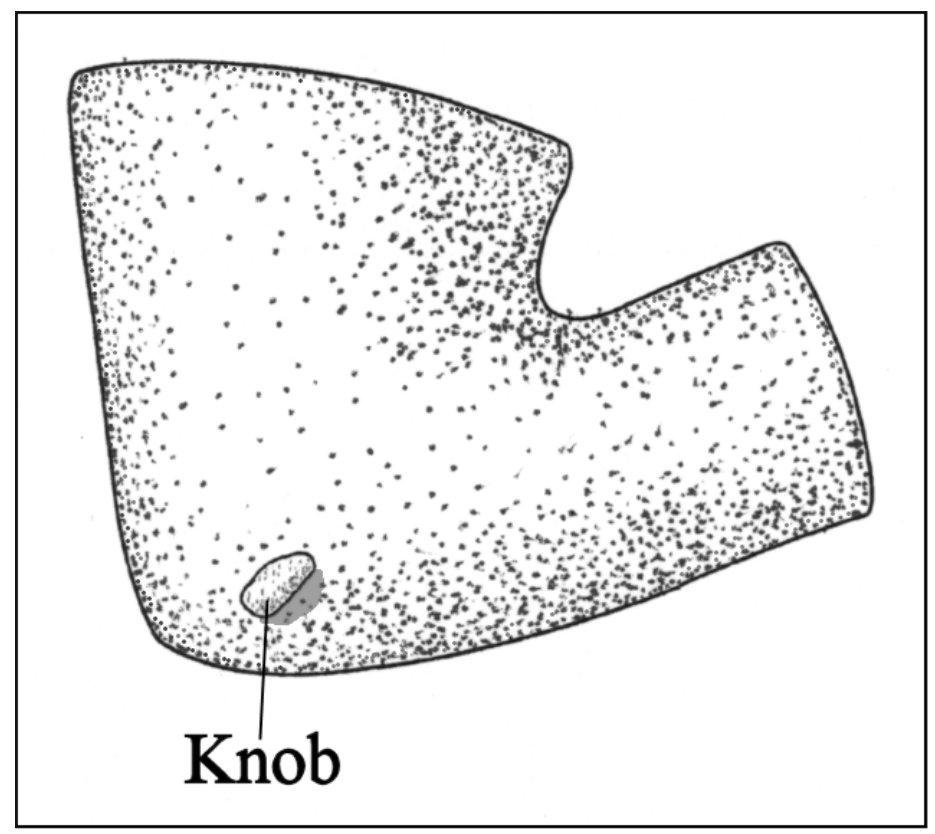

Figure 48. Plain elbow pipe.

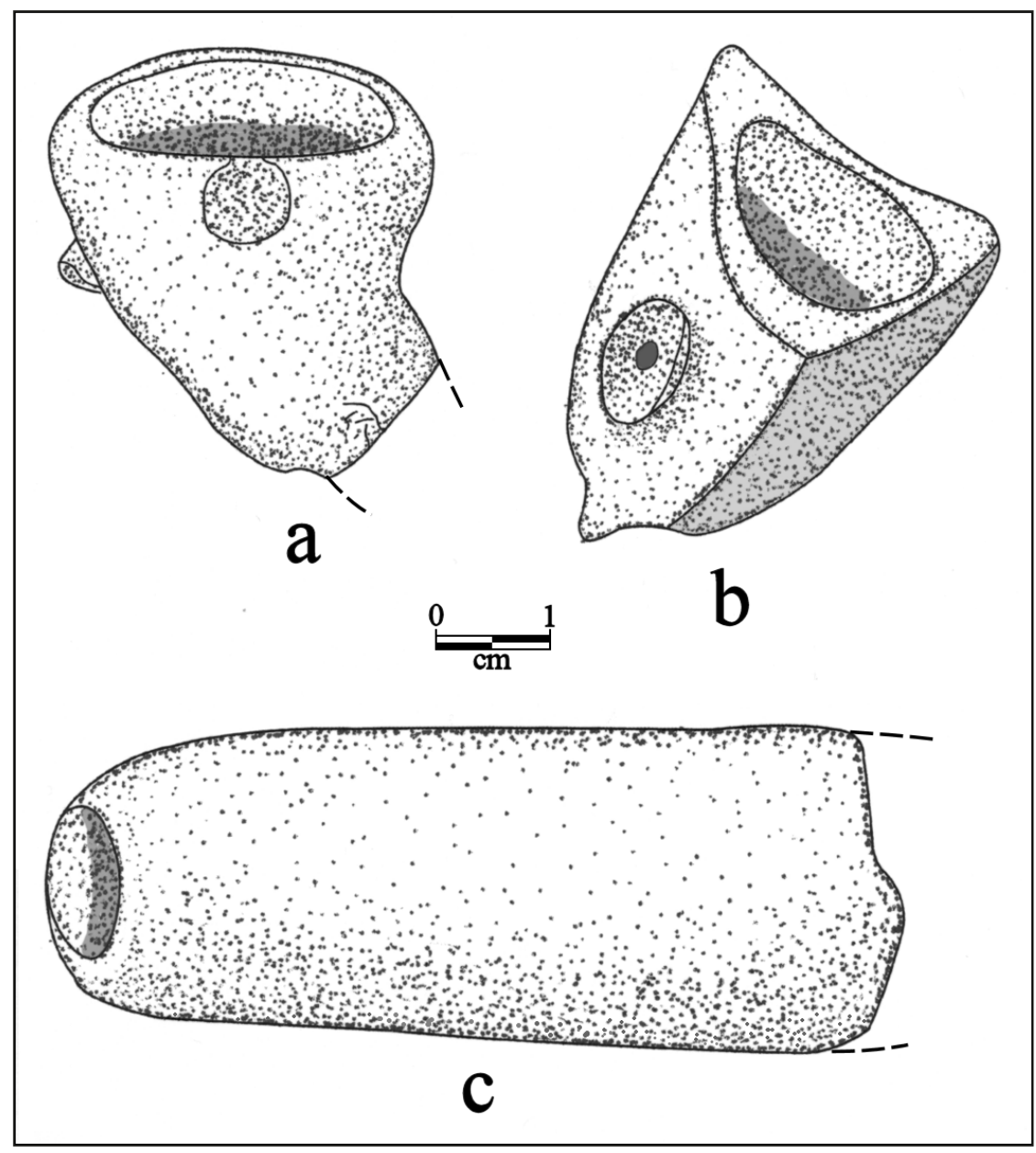

Figure 49. Other clay pipes from the Eli Moores site: a, elbow pipe; b, triangular-shaped pipe; c, tubular pipe. 


\section{Other Clay Artifacts}

There are remnants of clay pigments in the collection. This includes small chunks of a gray clay and a yellow clay (31 x $22 \mathrm{~mm}$ in length and width). There is also a possible clay coil fragment or vessel leg/ appendage (Lot 51), $19.4 \mathrm{~mm}$ in diameter and $33.0 \mathrm{~mm}+$ in length, as well as a $14.0 \mathrm{~mm}$ diameter clay coil fragment.

There are several large masses of daub and burned earth in the Eli Moores site collection, some of the daub being as much as $40-57 \mathrm{~mm}$ in thickness. The daub comes from both the mound excavations as well as midden excavations, and much of it is oxidized, suggesting the clay walls of structures burned in the open air, and were not extinguished or smothered by sediments before it was baked hard. Also in the collection is a single mud dauber nest, also indicative of a burned structure.

\section{Chipped and Ground Stone Analysis}

\section{Chipped Stone Tools}

There are 10 arrow points in the Eli Moores site chipped stone tools. Two are straight-stemmed and shouldered forms made from gray and brown chert. Another is a bi-pointed form (cf. Nodena type), 33 $\mathrm{mm}$ in length, $9 \mathrm{~mm}$ in width, and $4 \mathrm{~mm}$ thick, made from gray chert. One of the points is a Talco made from black Big Fork chert, and four others are triangular forms with flat bases. These are made from gray novaculite $(\mathrm{n}=2)$, Big Fork black chert, and Red River jasper (red variety). One cf. Perdiz point is also made from a black Big Fork chert, and a single Bassett point is made from a dark gray to black chert.

There are also two oval arrow point preforms (gray chert and quartzite) and an arrow point tip made from a dark gray chert. The lithic raw materials represented in the arrow points and arrow point preforms were likely obtained in nearby Red River gravels.

Other chipped stone tools in the assemblage include a single dart point fragment of dark gray chert, a large (102 x $38 \times 6.7 \mathrm{~mm}$ in length, width, and thickness) bifacial knive of dark gray chert, and six other bifaces (fragments and a bifacial preform). These are made from brown chert $(n=2)$, gray chert $(n=2)$, gray novaculite $(n=1)$, and dark gray novaculite $(n=1)$. One white chert flake tool has unifacial use-wear damage, and a grayish-brown chert flake has steep end and side use-worn edges indicating use as a scraping tool.

Finally, one polished sandstone pebble (40 x $30 \times 12 \mathrm{~mm}$ in length, width, and thickness) has a bifacially flaked edge, suggested it may have been used as a saw.

\section{Ground Stone Tools}

There are several kinds of ground stone tools in the Eli Moores assemblage. This includes four sandstone abraders or abrader fragments (Figure 50a), a quartzite pitted stone (with a $24 \mathrm{~mm}$ diameter pit on one face), a mano/pitted stone fragment of sandstone, a mano (62 x $42 \times 25 \mathrm{~mm}$ in length, width, and thickness) of Ouachita Mountains metamorphic rock with grinding on both surfaces, and two flat grinding slabs, one of sandstone ( $151 \times 103 \times 18 \mathrm{~mm}$ in length, width, and thickness) and the other made from ferruginous sandstone (94 x 66 x $14 \mathrm{~mm}$ in length, width, and thickness).

The collection has 11 celts or celt fragments with bifacial bits and flat or rounded butt ends (Figure $51 \mathrm{~b}-\mathrm{e})$, not including the celt from Burial J-2. They are made on Ouachita Mountains metamorphic rock 


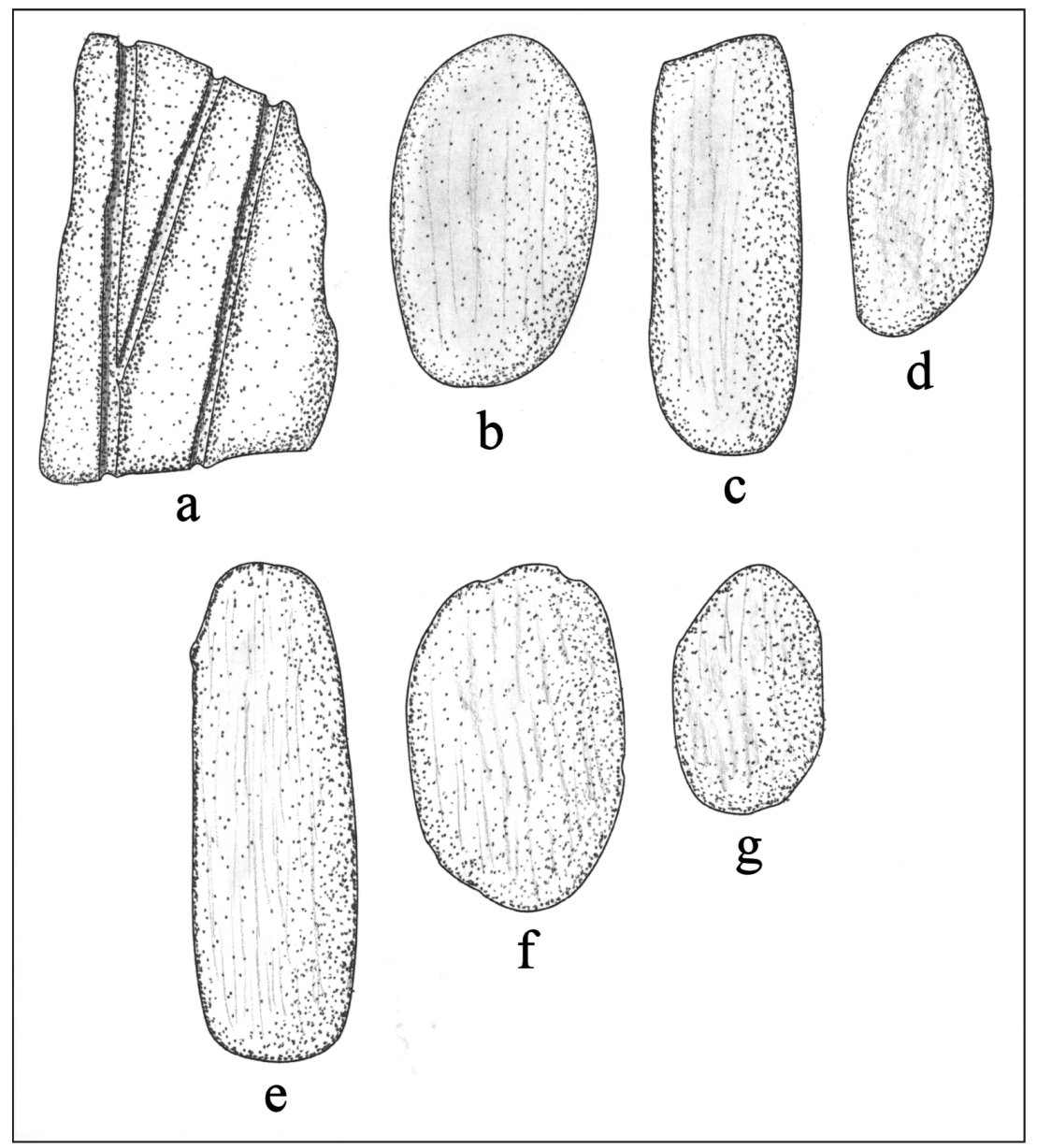

Figure 50. Lithic tools: a, abrader; b-g, chert polishing stones.

$(n=10)$, including greenstone and tuff, and hematite $(n=1)$. One of the larger celts $(97 \times 29 \times 15 \mathrm{~mm}$ in length, width, and thickness) is on a pebble with a polished face, chipped edges, and a well worn bit (19 $\mathrm{mm}$ in width). The other complete celts have bit widths that range from 37.7-40.0 mm and bit heights of 11.0-32.0 mm, with well polished and striated bifacial bits; lengths range from 76.5-121.5 mm, widths range from 43.9-56.1 mm, and they range in thickness from $29.5-55.9 \mathrm{~mm}$. The hematite celt $(76 \mathrm{x} 39 \mathrm{x}$ $17 \mathrm{~mm}$ in length, width, and thickness) has a polished body and a wide bit (38 mm); one of the Ouachita Mountains metamorphic rock celts has a $41.8 \mathrm{~mm}$ bit width.

One quartzite hammerstone is in the collection, along with a diorite or tuff pestle. The pestle has one blunt end with evidence of crushing (see Figure 51a), while the other end is rounded. The surface of the tool has pecking marks, but no polished surfaces. The tool is $165.0 \mathrm{~mm}$ in length, $55.9 \mathrm{~mm}$ in width, and $40.5 \mathrm{~mm}$ in thickness.

Finally, there are eight rounded pebbles and a polished cobble in the collection, likely used as polishing stones to finish the surface treatment of ceramic vessels made at the Eli Moores site. One is on quartzite, and two others are pieces of Ouachita Mountains metamorphic rock (i.e., greenstone). The other six are polished chert pebbles (see Figure 50b-g). These polishing stones range from 35.0-68.2 mm in length, $21.5-32.9 \mathrm{~mm}$ in width, and 10.2-26.1 $\mathrm{mm}$ in thickness. 


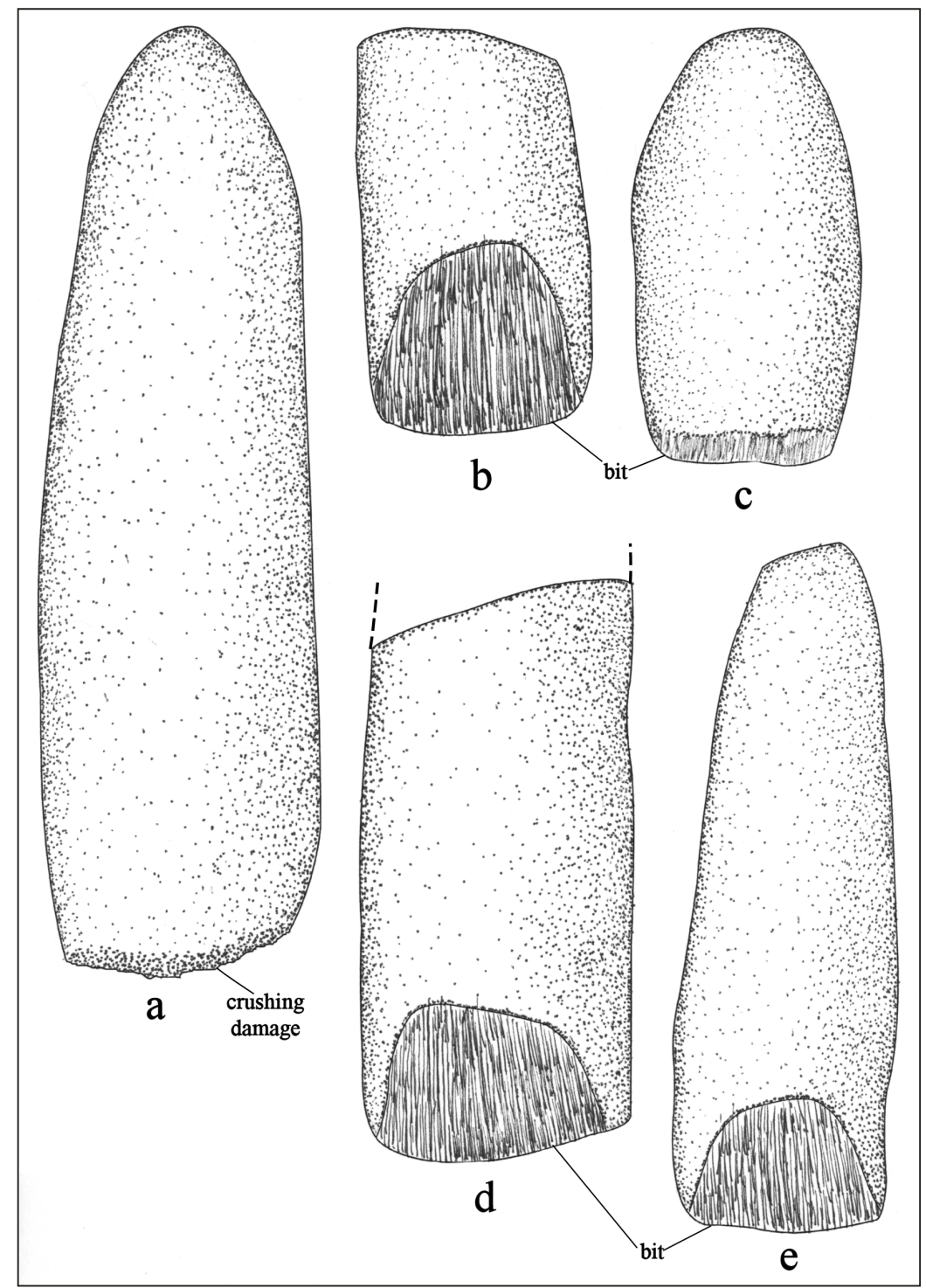

Figure 51. Ground stone tools: a, pestle; b-e, celts.

\section{Bone Tools}

Deer antler tools are common in the site collections, with 12 complete or fragmentary tools (Figure $52 \mathrm{c}-\mathrm{d}$ ); there also is an unmodified antler stub fragment that is at least $58.8 \mathrm{~mm}$ in length and $28.0 \mathrm{~mm}$ in width. The antler tools are polished, with either rounded $(n=5)$ or blunted $(n=7)$ ends. The complete tools range from 78.9-110.0 $\mathrm{mm}$ in length and from 18.0-23.9 $\mathrm{mm}$ in maximum width (near the base of the tool).

Other bone tools include one bird bowl awl (154.5 mm in length and a maximum of $24.3 \mathrm{~mm}$ in width) with a rounded and worn tip (Figure 53), a polished and grooved bird bone with a spur, and 12 deer ulna awls (see Figure 52a-b). The complete awls range from 93.0-157.0 mm in length and 32.4-44.1 mm in maximum width. 


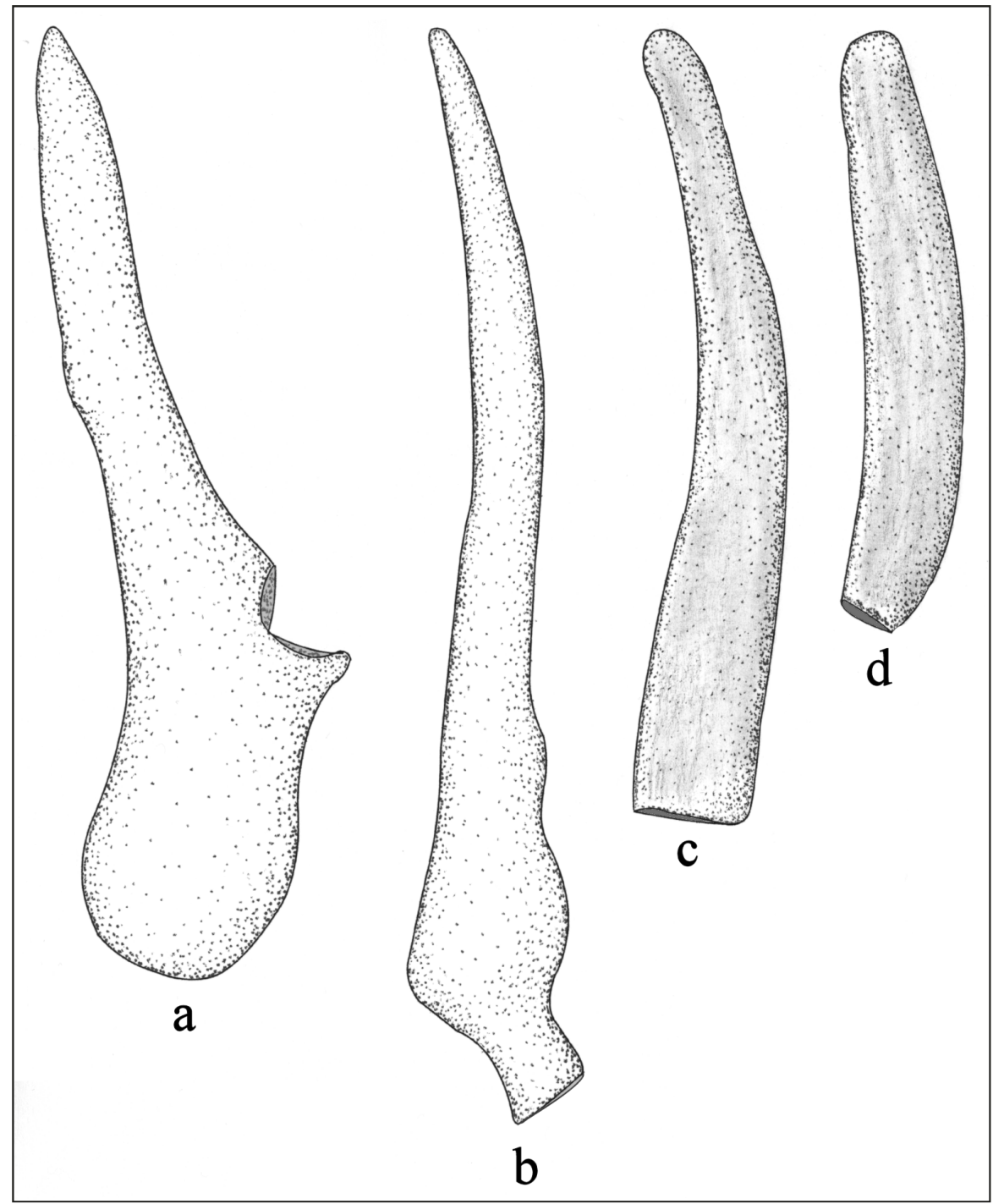

Figure 52. Bone and antler tools: a-b, awls; c-d, antler tines.

In addition to the various bone tools in the Eli Moores artifact assemblage, there is a large section of a deer cranium with attached antler stubs (Figure 54a). These stubs are a maximum of $33.0 \mathrm{~mm}$ in width where they meet the cranial bones.

There are four bear teeth from the Eli Moores investigations, three that are unmodified (and range from 45.1-56.9 $\mathrm{mm}$ in length). The one modified bear tooth is a pendant with a single $4.0 \mathrm{~mm}$ perforation near the root of the tooth (see Figure 54b-c). This tooth is $72.1 \mathrm{~mm}$ in length and $17.0 \mathrm{~mm}$ in maximum width.

\section{Mussel Shell Tools, Ornaments, and Unmodified Mussel Shell}

Five Lampsilis sp. mussel shell valves from the site have been modified by a single drilled perforation near the umbo (Figure 55c-d). The perforations range from 2.3-6.4 $\mathrm{mm}$ in diameter. These perforated mussel shells were probably ornaments in a necklace. There are also four unmodified Lampsilis sp. valves and valve fragments, along with a modified shell fragment (44.1 x $17.0 \mathrm{~mm}$ in length and width) with cut and smoothed edges that may be part of a shell inlay (Figure 55e). In addition, there are 35 unmodified Tritogonia verrucosa shell valves in the assemblage. 


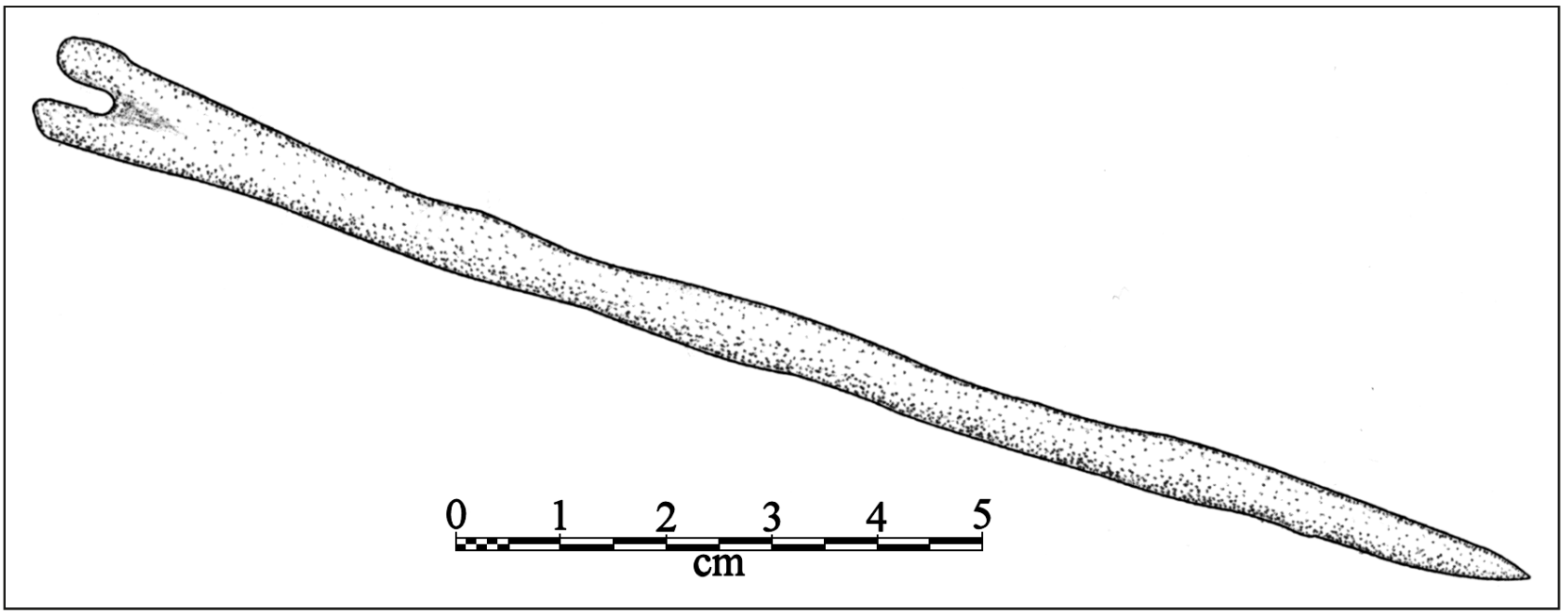

Figure 53. Bird bone awl.

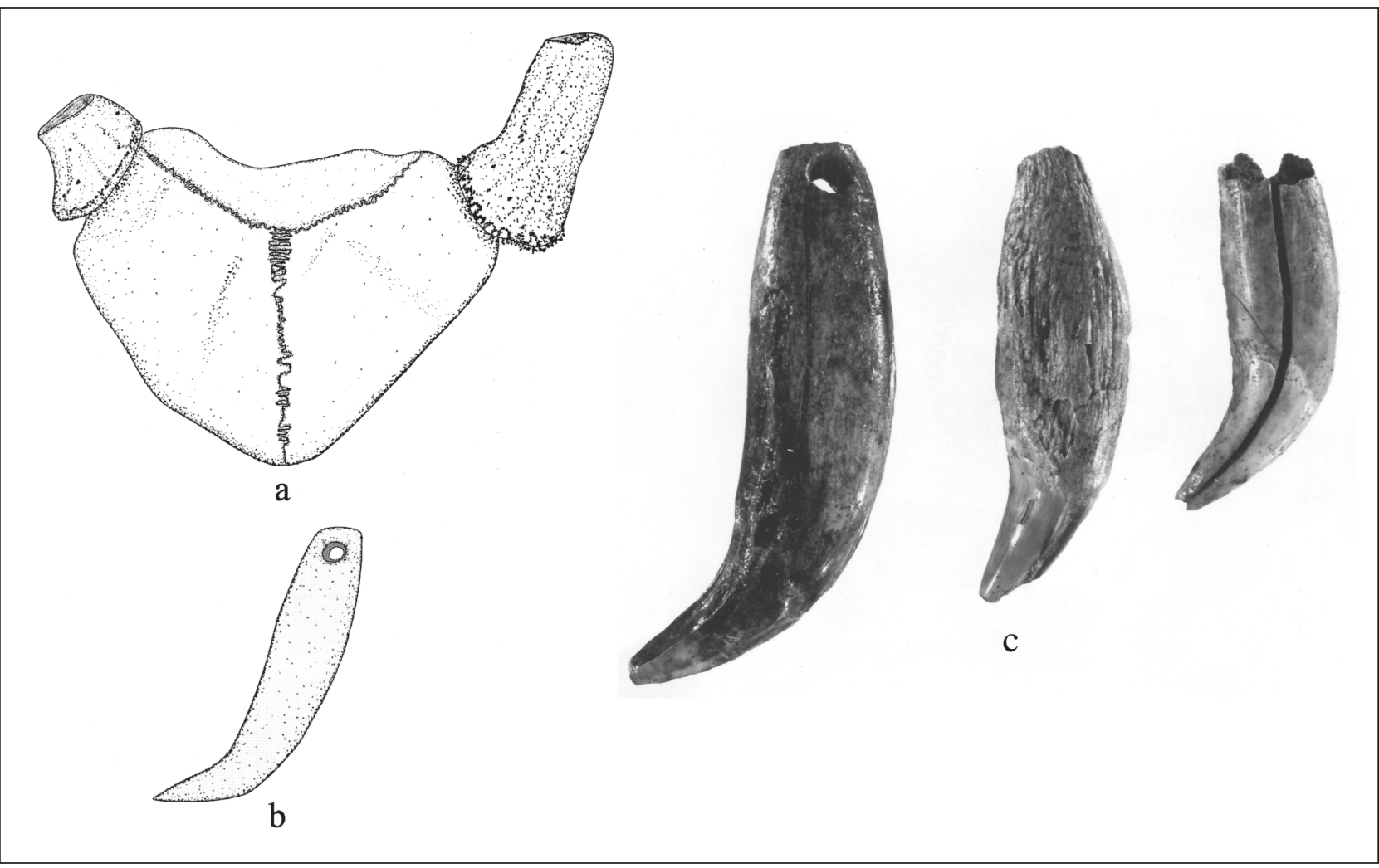

Figure 54. Other bone artifacts: a, deer cranium with attached antler stubs; $b$, drawing of perforated bear tooth; c, photograph of three bear teeth, 41BW2-22, courtesy of TARL.

There are larger Creodonta peruviana mussel shells in the collection, both unmodified $(\mathrm{n}=6)$ and modified $(\mathrm{n}=3)$. The modified valves are mussel shell hoes with single large (13.6-22.0 $\mathrm{mm}$ diameter) circular perforations (see Figure 55a). The circular perforation or drilled hole would have had a sturdy wooden stick placed in it to which the shell would have been hafted, creating a wood-handled hoe. The edges of the shell valves opposite the drilled holes have edge rounding and crushing, indicating this 


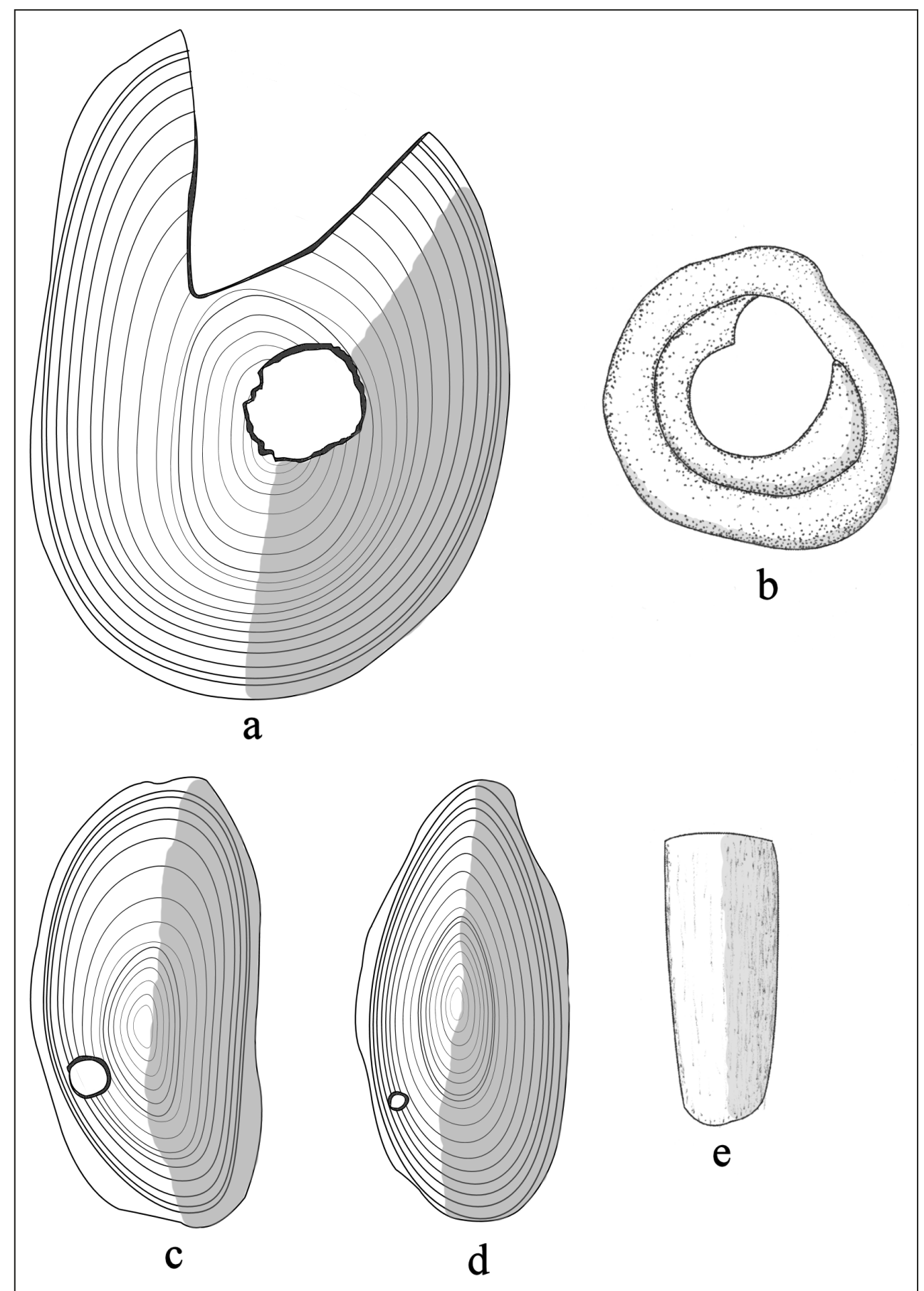

Figure 55. Mussel and conch shell artifacts from the Eli Moores site: a, mussel shell hoe; b, apex of columella shell; c-d, Lampsilis sp. perforated shells; e, possible shell inlay.

would have been the working edge of the hoe. Shell hoes are present in both domestic and mortuary contexts in other contemporaneous Caddo sites (Perttula et al. 2010:34-35; Webb 1959:175 and Figure 136). 


\section{Conch Shell}

There are two Busycon perversum conch shell artifacts in the Eli Moores collection from the 1932 UT excavations. The first is a small conch shell bead approximately $7.5 \mathrm{~mm}$ in diameter and $8.0 \mathrm{~mm}$ in length made from the columella. The other is an apical whorl fragment (see Phillips and Brown 1978:Figure 8) about $47.5 \mathrm{~mm}$ in width and $23.0 \mathrm{~mm}$ in diameter at the penultimate whorl (see Figure 55b); it is otherwise unmodified.

\section{European Trade Goods}

Glass beads were not found in the UT excavations at the Eli Moores site, but the landowner had found beads with several burials he had investigated subsequent to the UT work; a small sample of donated beads are in the TARL collections from the site. Furthermore, glass beads have been found on the surface of the site both before and after the UT investigations (Good 1977).

The glass beads are small (2.2 $\mathrm{mm}$ in diameter), rounded and drawn beads with simple or monochrome bodies, either an opaque blue ( $\mathrm{n}=15$, IIa40 in Kidd and Kidd [1970]) or an opaque white ( $\mathrm{n}=1$, IIa14). The Caddo preferred the color blue for fabrics (see Bolton 1987:133-134) as well as for the beads they used for ornamentation of their clothes and in necklaces. Glass beads are rare on Caddo sites before the first quarter of the 18th century, and trends in glass bead use on Caddo sites in the region suggest these beads likely date to the ca. 1700-1767 era (Perttula et al. 2010:Table 5). During this time period, beads tend to be small, drawn beads, likely "garment" or "embroidery" beads.

The two lead balls in the collection were found in the stomach area of Burial J-3, an adult male. The lead musket balls are approximately $9.5 \mathrm{~mm}$ in diameter. 


\section{Chapter 4, Analysis of the Plant Remains from the Eli Moores site (41BW2)}

Based on a November 2013 examination of the Eli Moores collection at TARL, the Eli Moores site collection has well preserved plant remains from mound midden and structure deposits. These include charred corn cobs, cultivated bean (Phaseolus vulgaris) (the beans were identified in 1933 by the Ethnobotanical Laboratory in the Museum of Anthropology at the University of Michigan), pecan and hickory nuts, a number of seeds, wood charcoal, and a section of charred cane basketry. Jackson (1932:40) identified pecan, hickory nuts, acorns, beans, squash seeds, and seeds resembling sunflowers.

Dr. Leslie Bush (Macrobotanical Analysis, Manchaca, Texas) has studied the remains and prepared a report on her findings that is presented below. The section of charred cane basketry was not removed from TARL, as Dr. Bush examined the basket fragments in the TARL facilities.

One of the corn concentrations included a number of charred corn cobs about $1.2 \mathrm{~m}$ east of Burial J-2 (Jackson 1932:20). The split cane basketry fragment (Figures 56 and 57) was recovered near the center of the mound at a depth of $53 \mathrm{~cm}$ bs (Jackson 1932:14), in the upper mound midden deposits. It was associated with a cache of 400+ charred pecan nuts (Jackson 1932:15); the basketry may have been part of a container that was holding the pecan nuts. One find in the southwest part of the mound, between a depth of $69-76 \mathrm{~cm}$ bs, was a concentration of charred cultivated beans associated with a broken ceramic vessel.

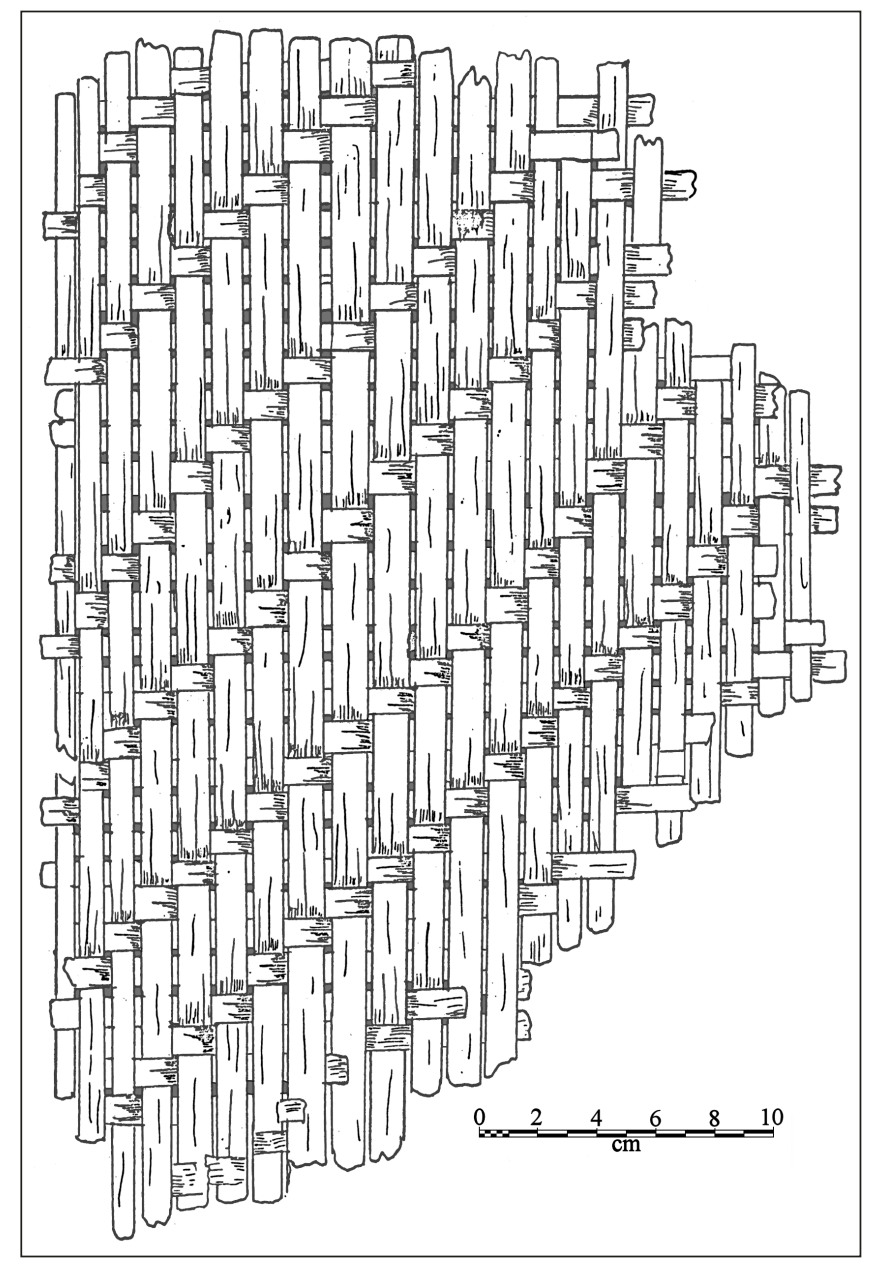

Figure 56. Drawing of split cane basketry fragment from the Eli Moores site. 


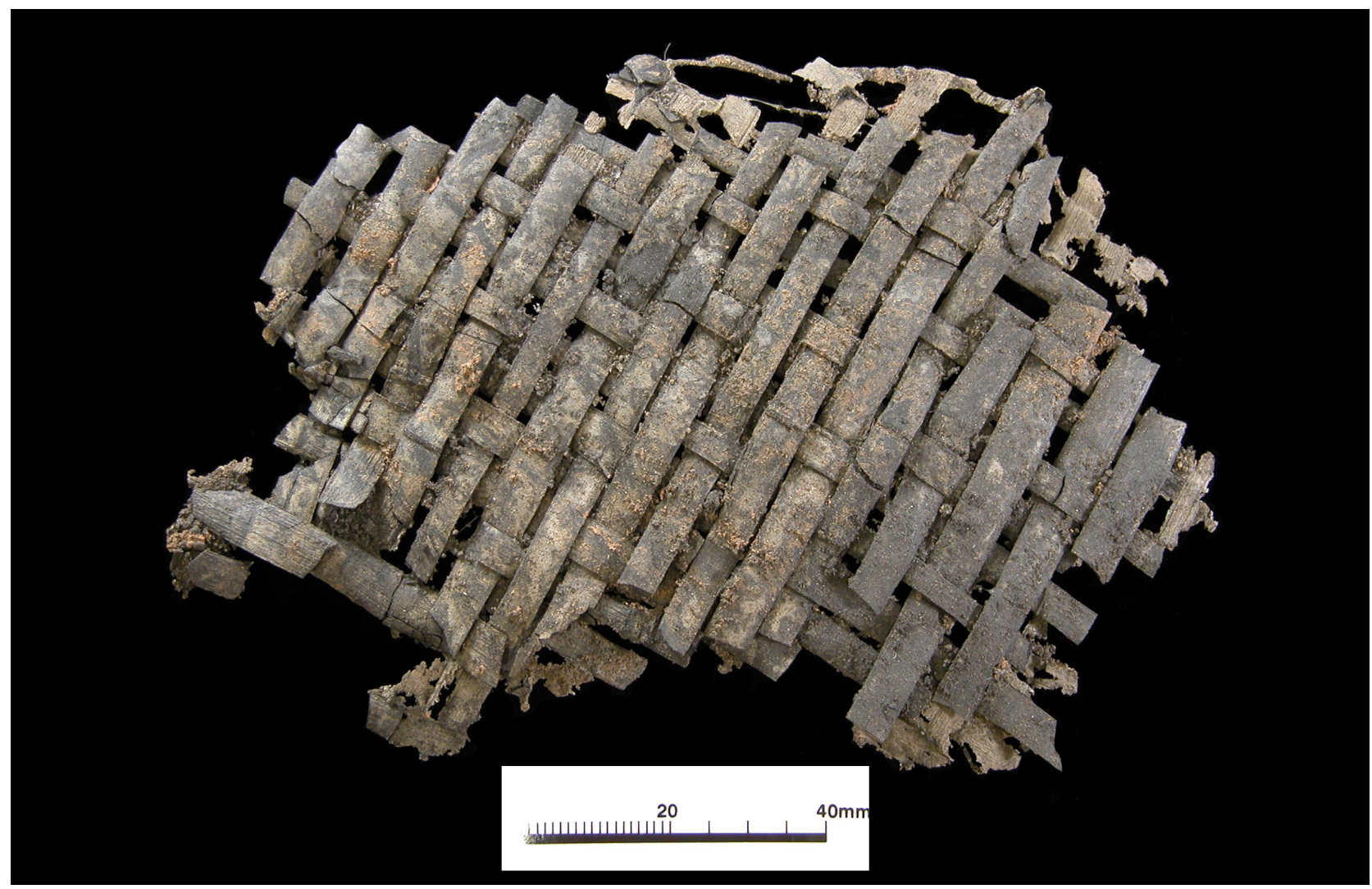

Figure 57. Split cane basketry. Photograph taken by Laura Nightengale, Texas Archeological Research Laboratory, The University of Texas at Austin.

\section{Eli Moores Site (41BW2) Plant Remains}

\section{Leslie L. Bush}

Botanical remains collected from the Eli Moores site (41BW2) by University of Texas excavations in 1932 were examined in the Texas Archeological Research Laboratory (TARL) in December 2013. The collection includes pecan nuts, parts of other nuts, corn, beans, wood charcoal, and two seeds. It also includes charred basketry fragments, a rarity on open sites in the Eastern Woodlands.

\section{Ecological setting}

The Eli Moores site lies in the meander belt of the Red River, a vegetation zone situated along the northeastern border of the state that is not well documented in Texas (but see Hoagland [1998] and Hoagland et al. [1996] for related work in Oklahoma). The comprehensive Flora of East Texas devotes only three pages to Red River vegetation (Diggs et al. 2006), and many state-wide descriptions of Texas flora omit the area altogether. The Red River vegetation zone is particularly narrow in Bowie County, since most of the floodplain is currently on the left (north) side of the river in that area and therefore belongs to the state of Oklahoma. Not surprisingly, plants of riparian zones tend to tolerate flooding and other disturbances better than their upland counterparts. A great many species may share the canopy in a floodplain forest, and "dominance is absent or poorly defined" (Lee 1945:163). Common trees of the Red River area include various types of oaks (Quercus spp.; post, water, Shumard, chinkapin, and bur), eastern red cedar (Juniperus virginiana), pecan and other hickories (Carya spp.), elms (Ulmus spp.), white ash (Fraxinus 
americana), roughleaf dogwood (Cornus drummondii), blackhaw viburnum (Viburnum prunifolium), sedges, and grasses and forbs (Bezanson 2000:57). Floodplains also support American beautyberry (Callicarpa americana), possumhaw (Ilex decidua), and Virginia creeper (Parthenocissus quinquefolia). Oxbows, sloughs, marshes and other wetlands associated with the Red River offer plant resources such as river cane, cattail and aquatic tubers or rhizomes including American lotus (Nelumbo lutea), waterlily (Nymphaea spp.), and spatterdock (Nuphar lutea).

Mean annual precipitation in Bowie County during the period 1951-1980 was 45.3 inches (1151 $\mathrm{mm})$. Precipitation is distributed fairly evenly over the year, with a slight peak in late spring. The frostfree season in Bowie County today averages 235 days and runs from March 21 through November 11 (NFIC 1987:57-58).

\section{Context and Methods}

The Eli Moores Site is a Caddo village, mound center, and burial ground that was apparently occupied from ca. the mid-16th century to the early 18th century. Clarence B. Moore noted "two mounds of moderate size" in the early 20th century (Moore 1912:637), but "no obvious mounds" were reported there in 1970 (THC Site Files, 8/1/1970) and their size likely has been diminished by plowing in modern times. Presently, however, Md. \#1 seems to be marked by a slight rise and a large pecan tree.

Much of the botanical collection from the site has been treated with a stabilizing agent, resulting in a shiny, transparent film over most of the specimens. Basketry fragments, pecans, beans, and corn cobs all appear to have received stabilizing treatments, while wood charcoal and small items frequently seem to have escaped this treatment. Based on the stylistic attributes of the associated tags, the botanical collection has been examined at least twice. The original, printed tags consist of short context descriptions while the apparently later tags (handwritten in red ink) assigned Item numbers. Different size fractions appear to have been created within Item numbers, probably using a 1/4-inch screen mesh. For this study, the smaller size fraction was further divided by screening through a No. 10 (2 mm square) mesh. At least two types of contexts are noted on the tags: a pecan deposit in Md. \#1 that also contained corn and beans and a midden deposit east of Md. \#1 that contained wood charcoal as well as pecan nuts; these "midden" pecans represent a second, separate cache (see Chapter 2, above). River cane stems were present in the midden context but not the other.

Although they were collected prior to the advent of radiometric dating methods, materials from Eli Moores were subject to full radiocarbon protocols during identification to retain whatever suitability they may have for radiocarbon dating. Samples were sorted on clean glassware and handled only with latex gloves and metal forceps. The nine samples that included small particles were placed on a No. 10 (2 mm) mesh to separate charcoal of identifiable size from sediment and charcoal flecks. Residue that fell through the mesh was examined under a stereoscopic light microscope to ensure that it contained only material consistent with that in the larger size fraction. Contact with paper and other plant products was avoided. Writing instruments used for data recording of samples were plastic mechanical pencils.

For each sample where wood charcoal was present, 20 fragments were selected for identification at random from those larger than $2 \mathrm{~mm}$. When fewer than 20 fragments were present in a sample, identification was attempted for all. Fragments were snapped to reveal a clean transverse section and examined under a stereoscopic light microscope at 28-45 X magnification. When necessary, tangential and radial sections were also created and examined.

For this analysis, materials were identified to plant part and taxon. Different plant parts and taxa were bagged separately, labeled, and returned to the original bag or box from which they came. A total of 14 
bags/boxes were examined. A 15th item, a jar of soil, was inspected for plant material through the glass. Only a few fragments of carbonized river cane were apparent, so the container was left untouched for future analyses.

Botanical materials were identified to the lowest possible taxonomic level largely though the author's previous knowledge of the taxa. Plant reference materials and a botanical library were not available at TARL, and transporting them was deemed unnecessary once it was discovered that there were no difficult or unusual taxa in the collection. When questions arose, the Macrobotanical Analysis comparative collection and standard reference works were consulted between microscope sessions at TARL (Core et al. 1979; Davis 1993; Hoadley 1990; InsideWood 2004; Martin and Barkley 2000; Musil 1963; Panshin and de Zeeuw 1980; Wheeler 2011). Botanical nomenclature follows that of the PLANTS Database (USDA, NRCS 2013).

\section{Results}

A summary of material from the Eli Moores botanical collection is shown in Table 9. Non-botanical items (bone, shells, fish scales, teeth, and a lithic flake) are listed in Table 10. Corn cob descriptions are shown in Table 11; cupule measurements are given in Table 12. The basketry fragments are described by protocols set out by James Adovasio (2010) in Table 13, and the largest fragment is pictured in Figures 56-57. A complete plant inventory list by bag/box with comments is provided in Table 14.

Table 9. Plants from pecan deposit and midden at the Eli Moores site.

\begin{tabular}{lrr}
\hline Collection totals & Number & Weight (g) \\
\hline Pecan (Carya illinoinensis), semi-carbonized & 7179 & 426.23 \\
Nuts, undifferentiated & 12 & 0.15 \\
Nutshell & 50 & 2.85 \\
Nutmeat & & 0.54 \\
Other nutmeat, carbonized & 1 & \\
Acorn (Quercus sp.) & & 0.46 \\
& & 0.01 \\
Other nutshell, carbonized & 4 & 19.97 \\
Hickory (Carya sp., thick) & 1 & 5.39 \\
Acorn (Quercus sp.) & & 14.93 \\
Corn (Zea mays), carbonized & 28 & \\
Cob fragments* & 78 & 0.12 \\
Kernels & & 0.01 \\
Common bean (Phaseolus vulgaris), carbonized & 229 & \\
Wild seeds, carbonized & & 1 \\
Persimmon (Diospyros virginiana) & 1 & \\
Sida (Sida sp.) & &
\end{tabular}


Table 9. Plants from pecan deposit and midden at the Eli Moores site, cont.

\begin{tabular}{lcc}
\hline Collection totals & Number & Weight (g) \\
\hline River cane stems (Arundinaria gigantea) & 63 & 1.37 \\
River cane basketry fragments (Arundinaria gigantea) & 5 & - \\
& & \\
Wood charcoal & & 43.38 \\
Mulberry (Morus rubra) & 36 & 5.14 \\
Ash (Fraxinus sp.) & 43 & 4.84 \\
Maple/box elder (Acer sp.) & 15 & 0.96 \\
Willow (Salix sp.) & 3 & 0.59 \\
American elm (Ulmus americana) & 4 & 0.53 \\
Holly/possumhaw (Ilex sp.) & 2 & 0.36 \\
Plum/cherry (Prunus sp.) & 5 & 0.19 \\
Eastern redcedar (Juniperus virginiana) & 3 & 0.06 \\
Pecan (Carya illinoinensis) & 2 & 0.06 \\
Indeterminable & 1 & 0.01 \\
Diffuse-porous hardwood & 1 & 16.38 \\
Not examined & 1022 & 0.22 \\
Bark, semi-carbonized & & 145.28 \\
Soil > 2mm & 2 & 120.44 \\
Residue < 2mm & & 0.06 \\
Modern detritus (staples and plastic) & & 0.08 \\
Uncarbonized pine (Pinus sp.) wood shavings & 3 & \\
\hline
\end{tabular}

*cob fragments and conjoined ranks of cupules; individual cupules and glumes not counted separately.

See Table 12 for measurements of indivudual cupules.

Table 10. Non-botanical items in the pecan deposit and midden from the Eli Moores site.

\begin{tabular}{lccl}
\hline Bag/Box & Item & Weight $(\mathrm{g})$ & Comments \\
\hline "Pecan Deposit" & Fauna & 0.74 & weight includes gelcap \\
"Pecans" (Jar) & Fauna & 1.60 & \\
Item \#2 & Fauna & 0.02 & bone \\
"Mound- Midden" & Fauna & 37.74 & shell, weight includes soil in bivalve \\
"Mound- Midden" & Fauna & 0.01 & fish bone \\
Item \#7 & Fauna & 0.46 & shell, bone, includes fish \\
Item \#6 & Teeth & 0.44 & 5 burned incisor roots; human or \\
& & & deer \\
Item \#5 & Fauna & 0.14 & bone, fish, scales \\
Item \#5 & Lithic, flake & 0.02 & chert \\
\hline
\end{tabular}


Table 11. Corn cob fragments (complete diameters) from the Eli Moores site.

\begin{tabular}{lrrr}
\hline Cob \# & 1 & 2 & 3 \\
\hline Fragment location & mid-shaft & mid-shaft & mid-shaft \\
Shape & cylindrical & cylindrical & narrowly tapered, curved \\
Length $(\mathrm{mm})$ & 15 & 15.8 & 28 \\
Cross-section shape & round & oval & oval \\
Diameter $(\mathrm{mm})$ & 9.8 & $15.1 \times 13.2$ & $14.2 \times 13.7$ \\
Row number & 10 & 10 & 16 \\
\hline
\end{tabular}

Table 12. Corn cupule dimensions from the Eli Moores site.

Cob \#1

Width (mm) Height (mm)

\begin{tabular}{|l|l|l}
\hline & 6.5 & 3.4 \\
& 6.5 & 3.4 \\
& 6.6 & 3.4 \\
& 6.8 & 3.4 \\
& 5.7 & 3.4 \\
& 6.6 & 3.5 \\
& 5.6 & 3.5 \\
& 5.9 & 3.5 \\
& 5.5 & 3.5 \\
& 5.3 & 3.2 \\
& 4.9 & 3.2 \\
& 5.1 & 3.2 \\
& 4.8 & 3.2 \\
& 6.5 & 3.7 \\
& 5.6 & 3.7 \\
& 5.7 & 3.7 \\
& 5.0 & 3.7 \\
& 5.7 & 3.6 \\
& 5.6 & 3.6 \\
$*$ & 5.7 & 3.6 \\
& 5.2 & 3.6 \\
\hline \multirow{6}{*}{ Mean } & $\mathbf{5 . 8}$ & $\mathbf{3 . 5}$
\end{tabular}

Incomplete diameters (conjoined and single ranks)

Width (mm) Height (mm)

$\begin{array}{ll}7.2 & 3.4 \\ 8.7 & 3.4 \\ 8.6 & 3.4 \\ 7.8 & 3.4 \\ 8.0 & 3.4 \\ 8.2 & 3.4 \\ 8.5 & 3.4 \\ 9.0 & 3.4 \\ 9.6 & 3.4\end{array}$

Incomplete diameters, cont. Width $(\mathrm{mm}) \quad$ Height $(\mathrm{mm})$

\begin{tabular}{ll}
5.9 & 3.3 \\
6.0 & 3.3 \\
6.0 & 3.3 \\
6.2 & 3.3 \\
6.4 & 3.6 \\
5.6 & 3.6 \\
6.0 & 3.6 \\
7.5 & 3.8 \\
6.8 & 3.8 \\
8.9 & 3.8 \\
6.6 & 2.9 \\
6.9 & 2.9 \\
6.7 & 2.9 \\
6.6 & 2.9 \\
6.8 & 3.8 \\
6.8 & 3.8 \\
6.7 & 3.8 \\
6.8 & 3.8 \\
6.6 & 3.8 \\
6.9 & 3.8 \\
7.1 & 3.5 \\
6.6 & 3.5 \\
6.7 & 3.5 \\
6.5 & 3.5 \\
6.2 & 3.5 \\
7.4 & 3.3 \\
7.7 & 3.3 \\
6.8 & 3.3 \\
7.3 & 4.0 \\
7.2 & 4.0 \\
7.7 & 4.0 \\
7.2 & 3.4 \\
6.7 & 3.4 \\
\hline & \\
\hline & \\
6.9
\end{tabular}


Table 12. Corn cupule dimensions from the Eli Moores site, cont.

\begin{tabular}{|c|c|c|c|}
\hline Width (mm) & Height (mm) & Width (mm) & Height (mm) \\
\hline 9.5 & 3.4 & 7.2 & 3.4 \\
\hline 8.3 & 3.4 & 6.7 & 3.4 \\
\hline 8.3 & 3.4 & 5.9 & 3.4 \\
\hline 6.8 & 3.4 & 6.5 & 2.7 \\
\hline 7.0 & 3.4 & 6.1 & 2.7 \\
\hline 6.8 & 3.4 & 6.0 & 2.7 \\
\hline 6.1 & 3.4 & 6.8 & 3.7 \\
\hline 6.5 & 3.4 & 7.0 & 3.7 \\
\hline 6.6 & 3.4 & 7.1 & 3.4 \\
\hline
\end{tabular}

Shaded indicates rank of cupules

*estimated dimension

Table 13. Description of basketry fragments from the Eli Moores site.

Site number

Site Name

Cultural Specimen

Specimen Unique Number

Completeness

Degree of Flexibility

Mended or Decorated

Form

Selvage

Center element

Plaiting Type

Shifts

Strip

Shape

Number

Orientation

Width

Distance between strips

Angle of crossing

Splices

Wear patterns

Carbonized

Wear from utilization

Sheen

Stain

Organic residue

Inorganic residue

Pitch
41BW2

Eli Moores

Textile, 5 fragments, probably basket based on curvature and association with plant food cache

Lot \#29 and Box 150 (loose cane strips)

Incomplete, largest fragment approx. $8.5 \times 6 \mathrm{~cm}$

Rigid

No

Unknown (fragmentary)

No

No

4/1 twill, one element acting as a unit

No

Flattened

Single

Side by side

Equal, $5.0 \mathrm{~mm}$ mean, 58 measurements

Equal, $1.0 \mathrm{~mm}$ mean, 26 measurements, 2 discarded as outliers 90

New elements laid in

Yes

No

Not determinable (stabilizer applied)

No

No

No

No 
Table 13. Description of basketry fragments from the Eli Moores site, cont.

Other

Strip preparation

Strip material
Stabilizer applied to material may obscure some wear, especially on reverse side

Plant stem, split longitudinally

Arundinaria gigantea

\section{Discussion}

\section{Carbonization status}

Most botanical items could be characterized as "carbonized," meaning that they were completely blackened by fire. Pecans in most boxes or bags consisted of incompletely carbonized specimens, usually dark brown (not fully carbonized throughout) but occasionally blacked on only one side of the specimen. These lots are characterized as "semi-carbonized," reflecting the mixed nature of most individual specimens and the lot as a whole. As indicated in Table 14, four pecan lots included only fully carbonized items. Only one type of plant material in the collection was completely uncarbonized: small shavings of fresh pine wood. Pine does not occur in the site area, but it does occur at TARL, where similar shavings from old collections drawers and drying racks can be found on the facility floors. The shavings are interpreted as 20th century curation debris.

\section{Corn (Zea mays)}

No whole corn cobs were present in the collection, but three cob fragments with complete diameters were recovered in Item \#4 (see Table 11). Item \#4 also included an additional five cob fragments with incomplete diameters. These cobs were split longitudinally but flattened so that row number could not be evaluated accurately. Two of the cob fragments with incomplete diameters retained the attached kernels. An additional 17 single or double ranks of cupules were present in Item \#4. The cupule measurements shown in Table 12 include all items where cupules could be measured. Fragments with attached cupules were not measured, nor were several specimens where dirt and stabilizing material obscured the corn anatomy.

\section{Seeds and nuts}

Most of the cultivated beans (Phaseolus vulgaris) in the collection were contained in the lots labeled "Kidney Beans" ( $\mathrm{n}=193)$ and "Beans picked from Pecan Cache" $(\mathrm{n}=32)$, but an additional four specimens were found among the material in Item \#2. One persimmon seed (Diospyros virginiana) was included in Item \#4 with the bulk of the corn. Persimmon is well-attested to as a Caddo food source, and Gaspar José de Solís suggests persimmon silviculture in his description of the fruit coming from "orchards" (Swanton 1996:132). A sida seed (Sida sp.) was found during microscope scanning of material smaller than 2 $\mathrm{mm}$ in Item \#7. Sida is a common, small-seeded anthropogenic weed. Three types of nuts were identified in the botanical collection: pecan hickory (Carya illinoinensis), thick-shelled hickory (Carya spp.), and acorn (Quercus spp.). Pecans were by far the most common plant type in the collection (426.23 g). They appear to have been in the shell when they burned. (Pecan husks remain on the trees, so husking is not a task associated with pecan processing.) 


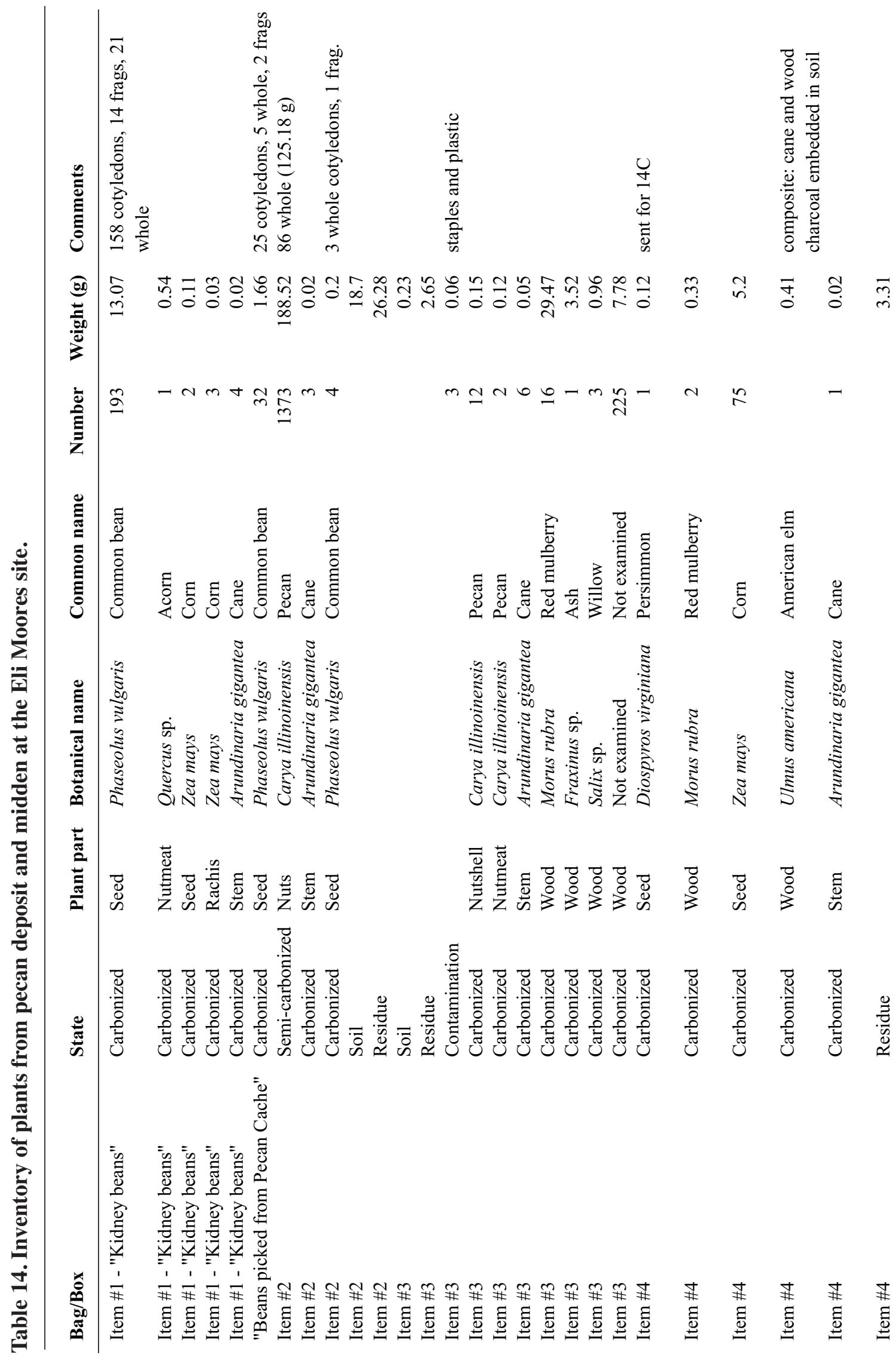




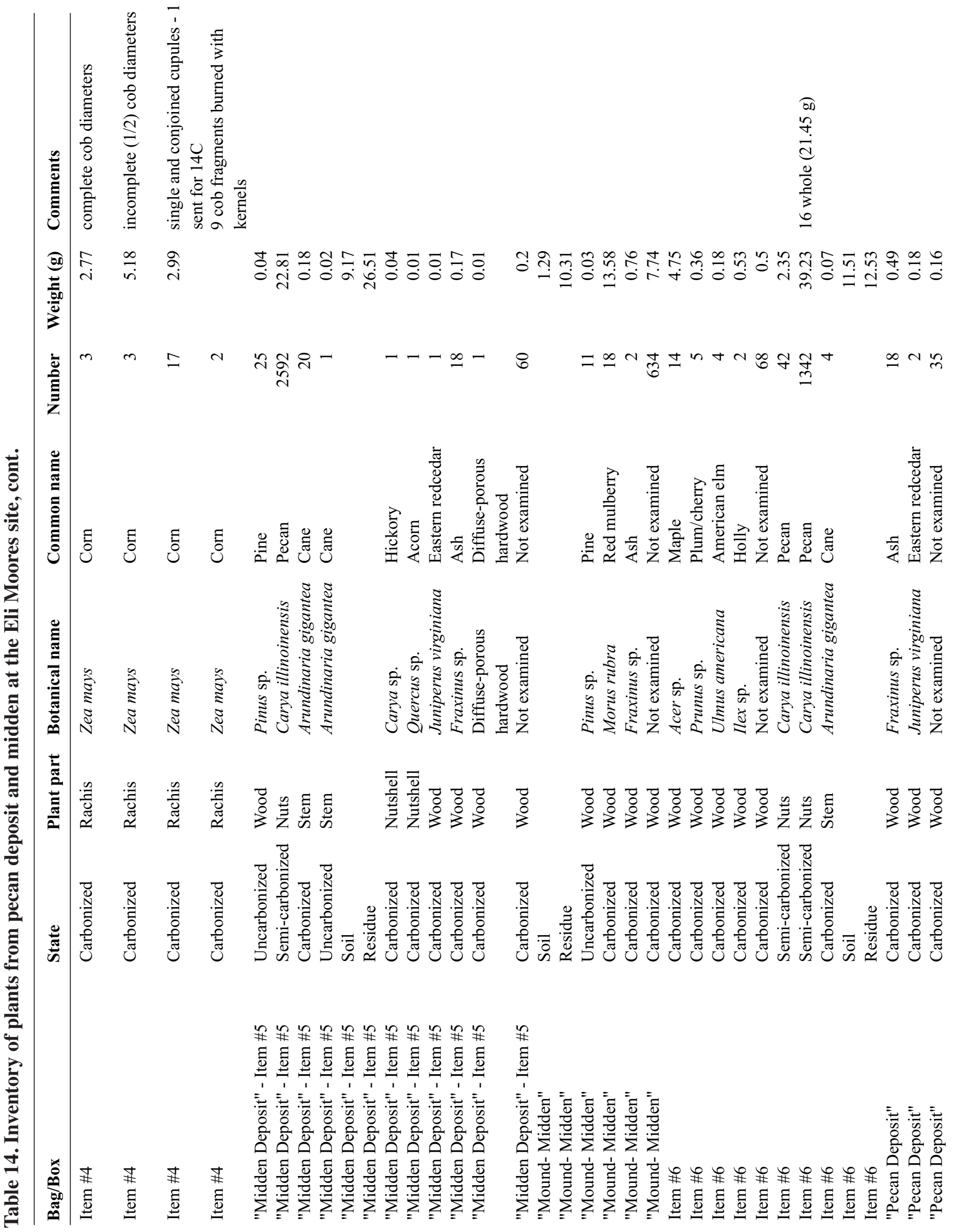




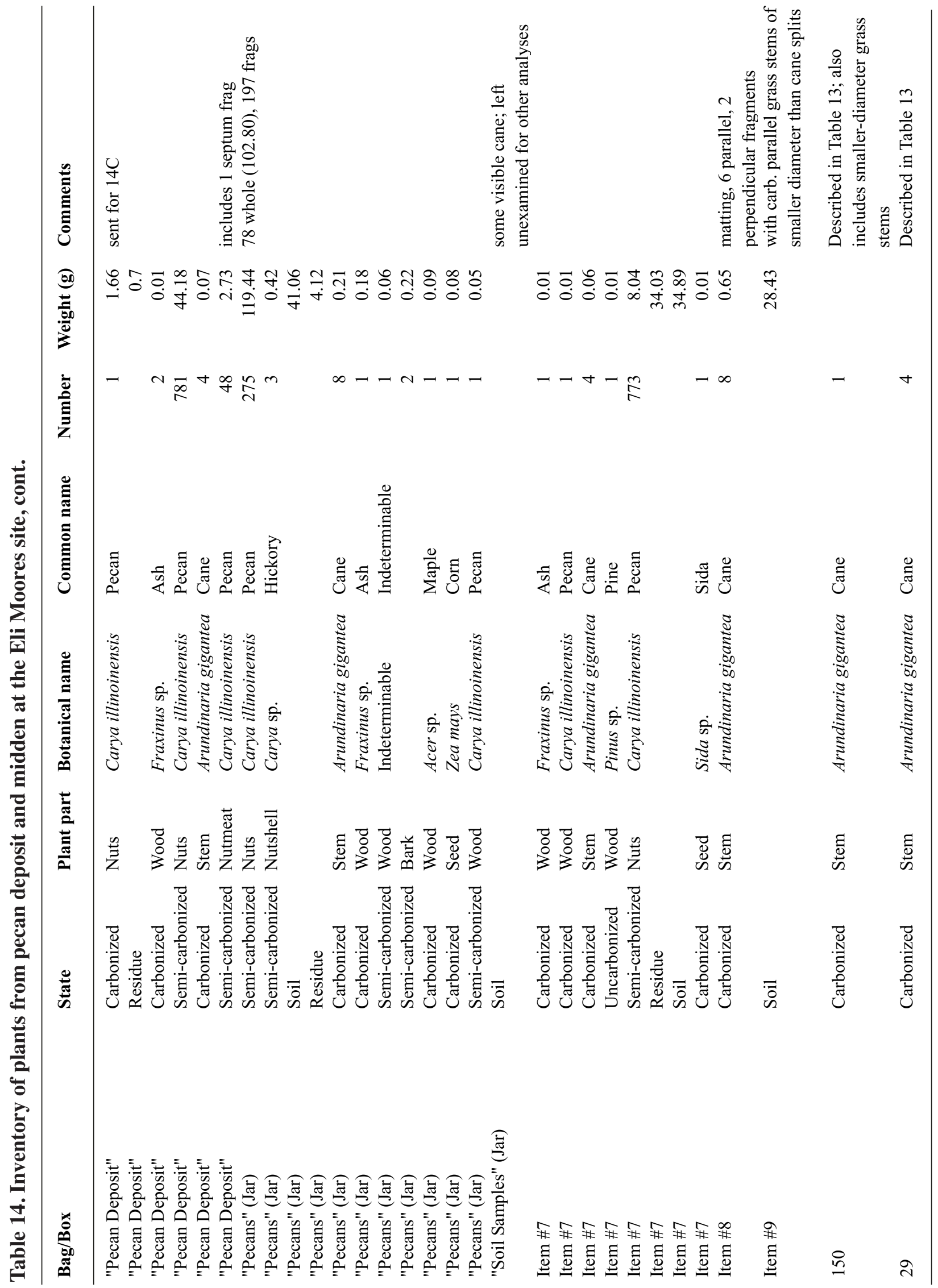




\section{Wood charcoal}

Nine types of wood were identified, all in carbonized form. All are common floodplain trees. High quality fuel woods such as oaks and true hickories are absent; as a group, the species represented would have made poor fuel. Ash (Fraxinus sp.) is notable as a good wood for basketry, since it splits readily into longitudinal (tangential) sections. No obvious ash basketry material was observed in the collection, however.

\section{Basketry fragment}

James Adovasio defines basketry as a sub-category of textiles that does not involve use of a loom. Matting is a special type of essentially two-dimensional basketry (Adovasio 2010:1). The five basketry fragments from the Eli Moores site collection do not permit definitive assignment of basketry form, but their association with a plant food cache and the slight curvature of the largest fragment indicates a three-dimensional basket rather than a mat. Like most of the collection, the basketry fragments have been treated with a stabilizing agent. The agent is especially noticeable on the reverse side of the basket. Although it has held the fragile, carbonized cane fragments in position, it obscures possible wear patterns and makes measurement of some elements difficult.

The basket was constructed with split cane elements (Arundinaria gigantea) in a technique known as "plaiting" where the warp and weft are both active. This basket was plaited in a four-over/one-under pattern with one element (i.e., one cane split) acting as a unit, crossing other elements at a ninety degree angle. The carbonized cane elements average $5.0 \mathrm{~mm}$ in width and are woven side by side (not overlapped), with a gap of approximately $1 \mathrm{~mm}$ between each element. No selvages (edges) or shifts (changes in pattern) were observed. A full description according to standard techniques may be found in Table 12. The largest, most complete fragment is pictured in Figures 56 and 57.

Two nearly identical basketry fragments are known from Caddo sites in the Arkansas Ozarks, Whitney Shelter (3BE20) and Brown Bluff (3WA10) (Scholtz 1975:72-73). A document from Fray Isidro Felis de Espinosa outlining early eighteenth century food storage practices at Mission La Purisima Conception on the Angelina River in East Texas describes a context in which the Eli Moores basket may have been used:

In their houses they have large baskets made of heavy reeds, into which they put their shelled corns and beans. In order that the weevil may not get in they cover the grain with a thick layer of ashes and they cover the baskets to keep out the rats (Hatcher 1927:156).

\section{Summary}

Plants recovered from excavations at the Eli Moores site in the 1930s include carbonized corn, beans, nuts (mostly pecan), a persimmon seed, wood, and split cane basketry fragments. Most of these may represent a single cache of food items that were burned when a Caddo structure was burned down and then covered with mound fill. Other remains came from a nearby midden that likely marks a non-mound habitation deposit. 


\section{Chapter 5, Radiocarbon Dating}

\section{Timothy K. Perttula and Robert Z. Selden Jr.}

There is an extensive radiocarbon database for East Texas, with more then 900 dates from Caddo sites (Perttula and Selden 2011). However, before this project, there were no absolute dates from the Eli Moores site, and the age of the site had not been definitively established. The presence of European trade goods in the deposits (i.e., glass beads, lead balls, and probable brass metal artifacts) indicates that some part of the Caddo occupation postdates ca. A.D. 1680/1690, when European artifacts brought by explorers and traders first appear on historic Caddo sites in East Texas (Perttula 1992). However, the beginning of the occupation (perhaps around ca. A.D. 1600, based on an examination of the decorated sherds in the assemblage) needs to be ascertained, and hopefully the results to be obtained from the radiocarbon samples selected from the site will provide that.

As part of the reanalysis of the Eli Moores site excavations, seven samples of organic remains - including corn, pecan nutshells, hickory nutshells, and even a small loose fragment from the cane matting - from the archaeological deposits in Mound No. 1 have been submitted for AMS radiocarbon dating, following the approval of TARL (Table 15). Before the radiocarbon samples of organic remains were submitted for AMS dating, Dr. Leslie Bush examined them in detail to identify, sort, and weigh all preserved organic remains. Three of the samples are from the cane and pecan cache, while the other four samples are associated with Item \#4 in Mound No. 1 (see Figure 7).

Table 15. Information on radiocarbon samples from the Eli Moores site.

\begin{tabular}{lll}
\hline Lab No. & Sample No. & TARL Information \\
\hline D-AMS 004819 & AEC-35 & Pecan shells in pecan deposit \\
D-AMS 004820 & AEC-36 & Cane matting associated with pecan deposit \\
D-AMS 004821 & AEC-37 & Item \#4, carbonized persimmon seed \\
D-AMS 004822 & AEC-38 & Item \#4, corn kernels \\
D-AMS 004823 & AEC-39 & charred beans from pecan deposit \\
D-AMS 004824 & AEC-40 & Item \#4, corn cupules \\
D-AMS 004825 & AEC-41 & Item \#4, corn cupules \\
\hline
\end{tabular}

The summed probability distribution of the seven calibrated radiocarbon dates from the Eli Moores site indicate that the likeliest temporal range at two sigma (95 percent probability) of the Caddo occupation was between cal. A.D. 1400-1660 (Figure 58). The major peaks in probability density are at ca. A.D. 1460-1520 and A.D. 1580-1640. There are minor peaks at ca. A.D. 1320, A.D. 1400, and A.D. 1790. The median calibrated age ranges span the period from A.D. 1403-1648 (Table 16).

The calibrated age ranges with the highest probabilities from the charred matting/pecan deposit in the mound are A.D. 1448-1530 (0.50), A.D. 1487-1651 (0.95), and A.D. 1620-1670 (0.57), with median calibrated ages ranging from A.D. 1527-1648. This indicates this deposit dates to the latter years of the Texarkana phase, but before the historic Nasoni Caddo occupation of the Eli Moores site. The calibrated age ranges with the highest probabilities from the Item \#4 deposit in the mound are A.D. 1388-1436 (0.64), A.D. 1445-1522 (0.71), A.D. 1450-1524 (0.59), and A.D. 1541-1635 (0.53), with median calibrated ages ranging from A.D. 1403-1558. This particular deposit of charred plant remains generally dates prior to the charred matting/pecan deposit in the mound, and falls in the early years of the Texarkana phase. 


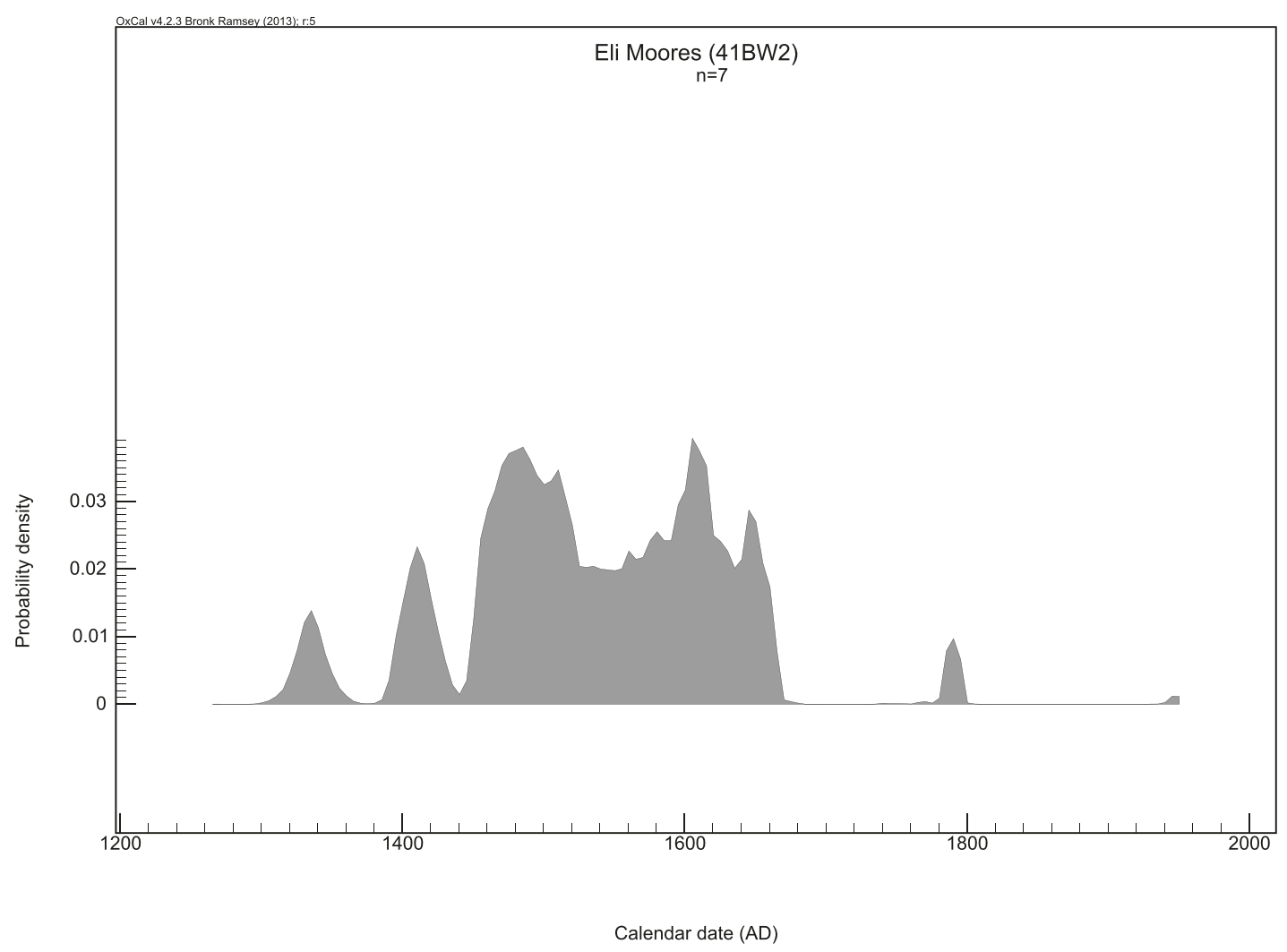

Figure 58. Summed probability distribution of calibrated radiocarbon dates from the Eli Moores site. Figure prepared by Robert Z. Selden Jr.

Table 16. Calibrated radiocarbon age ranges from the Eli Moores site.

\begin{tabular}{llll}
\hline Assay \# & $\begin{array}{l}\text { Conventional 14C } \\
\text { Age (B.P.) }\end{array}$ & $\begin{array}{l}\text { Two Sigma } \\
\text { Calibrated Age } \\
\text { (A.D.) }\end{array}$ & $\begin{array}{l}\text { Median } \\
\text { Calibrated Age } \\
\text { (A.D.) }\end{array}$ \\
\hline 004819 & $260 \pm 28$ & $\begin{array}{l}1521-1592(0.26), \\
1620-1670(0.57)\end{array}$ & 1648 \\
004820 & $365 \pm 34$ & $1448-1530(0.50)$, & 1527 \\
004821 & $384 \pm 24$ & $1540-1635(0.46)$ & $1445-1522(0.71)$, \\
004822 & $542 \pm 30$ & $1575-1624(0.24)$ & 1487 \\
004823 & $307 \pm 31$ & $1316-1355(0.32)$, & 1403 \\
004824 & $351 \pm 24$ & $1488-1436(0.64)$ & $1561(0.95)$ \\
004825 & $370 \pm 24$ & $1457-1530(0.43)$, & 1558 \\
& & $1541-1635(0.53)$ & $1509-1524(0.59)$, \\
\end{tabular}

Note: All assays done by Direct AMS. 


\section{Chapter 6, Summary and Conclusions}

The Eli Moores site (41BW2) is an important ancestral Caddo mound center (with two mounds) and habitation site on a natural levee of the Red River in the East Texas Pineywoods, likely part of the Nasoni Caddo village visited by the Teran de los Rios entrada in 1691. The site may have been the residence of the caddi of the Nasoni Caddo when it was visited by the French and Spanish, and the Xinesi lived in a temple on the mound at the nearby Hatchel site. The site was investigated by the University of Texas in 1932, and in one of the mounds and in associated midden deposits, the remains of Caddo structures, midden deposits, features, eight burials (with nine individuals), and a large ceramic and lithic assemblage were recovered, along with well-preserved plant and faunal remains. This report is a reanalysis of the existing 1932 excavation and feature records as well as the recovered artifact assemblage and plant remains that are curated at the Texas Archeological Research Laboratory at The University of Texas at Austin (TARL) and presents in detail the significant archaeological findings of the 1932 excavations.

The University of Texas 1932 excavations at the Eli Moores site concentrated on Mound \#1. This mound was estimated to be ca. $20 \mathrm{~m}$ in diameter and $1.5 \mathrm{~m}$ in height, and there was a borrow pit directly north of the mound. A blue glass bead had been previously found on the surface of the mound. Mound \#2 is ca. $12 \mathrm{~m}$ southwest of Mound \#1, while an unexplored mounded midden deposit is ca. $15 \mathrm{~m}$ south of Mound \#1. Mound \#2 had a small "test hole" excavated in it by the UT crew, but only midden deposits were encountered there; a small borrow pit was located just south of this mound. Jackson also noted that there were several midden deposits north and east of Mound \#1, one of which had much daub, suggesting it was the location of a burned clay and thatch-covered structure. In another midden deposits (about $45 \mathrm{~m}$ east of Mound \#1, a Caddo burial (J-1) and a flexed dog burial (Feature 1) were discovered lying about $1.8 \mathrm{~m}$ apart in the excavations; the small to medium-sized adult dog may have been associated with the Caddo burial as it lay near the feet of the deceased Caddo adult.

The excavations in Mound \#1 proceeded first through the excavation of $1.5 \mathrm{~m}$ wide north-south and east-west trenches that cut across much of the mound, and then much of the central portion of the mound was excavated. These excavations encountered evidence of two wood structures (that may have been burned down), an ash pit, and seven burials (J-2 to J-8). Six of the burials (and seven individuals) are children less than 6-7 years of age at their death, while Burial J-3 is that of an adult Caddo male; this burial may have been intrusive into the mound, while the others were likely buried during the accumulation of the mound midden deposits. Funerary offerings with the burials included 10 ceramic vessels or broken vessel sections, four Maud arrow point and a Maud point preform, one Bassett point, a celt, a conch shell bead, three Olivella sp. shell beads, mussel shells, a drilled turtle shell, a deer mandible and several long bones, a broken but smoothed raccoon bacculum bone, and a bone needle. Burial J-3 had two lead balls in its rib cage, probably the cause of death.

Profiles on the north and south sides of the north-south trench bisecting Mound \#1 indicates that the mound deposits were comprised of stratified midden deposits and a clay zone, the latter perhaps indicative of either structural zones or clay caps in the mound fill. The mound fill comprised of midden deposits also contained evidence for the burning of structures as well as much wood, producing a $92 \mathrm{~cm}$ thick deposit with quantities of ash, burned clay, and charcoal. The red clay zones were used to first create a mound platform (125-155 cm bs) and then also as a mound fill capping event $(10-33 \mathrm{~cm} \mathrm{bs})$.

Mound \#2 was dug into by the landowner, Eli Moores, after the UT work at the site. Moores wrote a letter to A. T. Jackson in 1933, indicating that he had excavated five burials at that time, along with 18 associated ceramic vessels and several hundred glass beads. Moores also found nine metal artifacts, made 
either from brass, copper, or bronze, with these burials. Moores continued to dig at the site, and by 1935 had discovered 10 or 11 burials and additional ceramic vessels.

The 10 vessels from the burials at the Eli Moores site are from Texarkana phase burials. They include plain bowls ( $\mathrm{n}=2)$, an incised-punctated jar, an appliqued jar, and a Karnack Brushed-Incised jar, as well as a Simms Engraved carinated bowl, an engraved bottle with a pendant triangle element on the body, a Belcher Engraved, var. Belcher compound bowl, and two Barkman Engraved carinated bowls.

Plain rims are common in the Eli Moores ceramic assemblage, suggesting that plain ware vessels (jars, bowls, and bottles) were a significant component of the overall assemblage made and used at the site. These plain rims represent 27.4 percent of all the rims in the ceramic collection; utility ware rims account for 19.5 percent of the sample, and 53.2 percent of the rims are from fine ware vessels. Sherds are from vessels most commonly tempered with grog ( 84.9 percent), followed by bone ( 9.4 percent), and shell (5.7 percent). The low percentages of shell-tempered sherds in the ceramic assemblage suggests that they are from vessels made in other Caddo ceramic production areas on the Red River where the use of shell temper was considerable after the 15th century A.D., including the middle Red River and McCurtain phase Caddo groups and among certain Belcher phase Caddo groups in the Great Bend area.

The decorated ceramic assemblage from the 1932 investigations at the Eli Moore site includes 1223 rim and body sherds. The decorated sherds are divided into utility wares $(n=554,45$ percent of the decorated sherds) and fine wares ( $n=669,55$ percent); the proportion of fine wares is notable.

Several different kinds of utility wares are represented, principal among them are sherds with incised, brushed, appliqued, punctated, and trailed-incised decorative elements from Emory Punctated-Incised, Foster Trailed-Incised, Karnack Brushed-Incised, and McKinney Plain vessels. There are also Cowhide Stamped, Moore Noded, Nash Neck Banded, Pease Brushed-Incised, and Belcher Ridged, var. Belcher sherds in the utility wares.

The 669 fine ware sherds in the Eli Moores ceramic assemblage are dominated by sherds from vessels with engraved and excised elements (91 percent), principally from Barkman Engraved and Simms Engraved vessels. The remainder of the fine ware sherds have red-slipped (3.5 percent) and trailed (5.5 percent) decorative elements, the latter from Keno Trailed bowls and bottles. The constellation of engraved and trailed fine ware types at sites such as Eli Moores and Hatchel (41BW3) suggest that the principal occupation at Eli Moores and other Nasoni Caddo sites is contemporaneous with the latest Belcher phase (Belcher IV) occupation at the Belcher site, and at the late 17th century to early 18th century component at the Chakanina phase Cedar Grove site (3LA97) in southwest Arkansas. Sherds from Simms Engraved and Barkman Engraved vessels dominate the fine wares from the Eli Moores site, accounting for about 58 percent of all the fine ware rims and ca. 30 percent of the body sherds. The similarities in design element structure and design elements between Simms Engraved and Barkman Engraved (i.e., narrow horizontal bands with a row of excised punctates), and the generally younger (ca. post-A.D. 1600) age of Simms Engraved vessels from other Red River contexts suggests that Simms Engraved is a stylistically linked evolution from later versions of Barkman Engraved fine wares in this part of the Red River basin.

Other identified fine ware engraved ceramic types in the assemblage include Avery Engraved, Belcher Engraved, Natchitoches Engraved, Hodges Engraved, Hatchel Engraved, Taylor Engraved, and Glassell Engraved. Only the Barkman Engraved, Hatchel Engraved, and Simms Engraved fine wares were likely produced locally by Red River Caddo potters, but the other defined ceramic types were likely manufactured by contemporaneous Great Bend Belcher phase Caddo potters living downstream along the Red River and major tributaries. A distinctive but untyped category of engraved fine wares from the Eli 
Moores site have scroll elements and hatched scroll fill elements as well as hatched or excised bracket dividers. Most of these sherds have either horizontal scroll bands, or slanting scrolls, with upper and lower scroll fill zones with open or cross-hatched triangle elements.

The trailed fine ware sherds are from Keno Trailed bowls and bottles. The bowls have horizontal and curvilinear elements on the rim portion of the vessel as well as multiple curvilinear trailed lines covering the vessel body. Keno Trailed bottle sherds have curvilinear, multiple curvilinear, and diagonal opposed and curvilinear trailed lines on the vessel body. These sherds may be from Keno Trailed, var. McClendon vessels.

Other ceramic material culture items in the Eli Moores assemblage include spindle whorls $(n=17)$, elbow pipes $(n=2)$, and a tubular pipe. There are also gray and yellow clay pigments and a possible clay coil fragment or a vessel leg/appendage.

Lithic artifacts at the site are represented by 10 arrow points, including a cf. Nodena, one Talco, one Perdiz, one Bassett, and four Maud points. These were made from high-quality Red River and Ouachita Mountains cherts and novaculite. There is also a single dart point fragment, a large bifacial knive, six biface fragments, a flake tool, and a polished sandstone pebble. Ground stone tools include four sandstone abraders or abrader fragments, a quartzite pitted stone, a mano/pitted stone fragment of sandstone, a mano of Ouachita Mountains metamorphic rock with grinding on both surfaces, a quartzite hammerstone, eight rounded pebbles and a polished cobble, and two flat grinding slabs. The collection from the Eli Moores site has 11 celts or celt fragments with bifacial bits and flat or rounded butt ends, as well as a celt from Burial J-2. They are made on Ouachita Mountains metamorphic rock, including greenstone and tuff, and hematite.

There is an interesting assortment of bone tools in the Eli Moores assemblage. This includes 12 deer antler tools and an unmodified antler stub fragment. The antler tools are polished, with either rounded or blunted ends. Other bone tools include one bird bowl awl with a rounded and worn tip, a polished and grooved bird bone with a spur, and 12 deer ulna awls. In addition to the various bone tools, there is a large section of a deer cranium with attached antler stubs. There are also four bear teeth from the Eli Moores investigations, three that are unmodified. The one modified bear tooth is a pendant with a single perforation near the root of the tooth.

Five Lampsilis sp. mussel shell valves from the site have been modified by a single drilled perforation near the umbo. These perforated mussel shells were probably ornaments in a necklace. There are also four unmodified Lampsilis sp. valves and valve fragments, along with a modified shell fragment with cut and smoothed edges that may be part of a shell inlay. In addition, there are 35 unmodified Tritogonia verrucosa shell valves in the assemblage.

There are larger Creodonta peruviana mussel shells in the collection, both unmodified and modified. The modified valves are mussel shell hoes with single large circular perforations. The edges of the shell valves opposite the drilled holes have edge rounding and crushing, indicating this would have been the working edge of the hoe.

There are two Busycon perversum conch shell artifacts in the Eli Moores collection from the 1932 UT excavations. The first is a small conch shell bead made from the columella. The other is an apical whorl fragment; it is otherwise unmodified. 
There are European trade goods in the Eli Moores artifact assemblage. Glass beads were not found in the UT excavations at the Eli Moores site, but the landowner had found beads with several burials he had investigated subsequent to the UT work; a small sample of donated beads are in the TARL collections from the site. Furthermore, glass beads have been found on the surface of the site both before and after the UT investigations. The glass beads are small ( $2.2 \mathrm{~mm}$ in diameter), rounded and drawn beads with simple or monochrome bodies, either an opaque blue $(n=15)$ or an opaque white $(n=1)$. The Caddo preferred the color blue for fabrics as well as for the beads they used for ornamentation of their clothes and in necklaces. Glass beads are rare on Caddo sites before the first quarter of the 18th century, and trends in glass bead use on Caddo sites in the region suggest these beads likely date to the ca. 1700-1767 era. During this time period, beads tend to be small, drawn beads, likely "garment" or "embroidery" beads.

The two lead balls in the collection were found in the stomach area of Burial J-3. The lead musket balls are approximately $9.5 \mathrm{~mm}$ in diameter.

Botanical remains were collected from the Eli Moores site by University of Texas excavations in 1932, and were examined for this project by Leslie L. Bush. The collection includes pecan nuts, many in a cache associated with basketry, parts of other nuts (hickory and acorn), corn (cob fragments and cupules), cultivated beans (Phaseolus vulgaris), wood charcoal from common floodplain trees, and two seeds (persimmon). It also includes five charred basketry fragments made from split river cane (Arundinaria gigantea), a rarity on open sites in the Eastern Woodlands. Most of these remains likely represent a single cache of food items that were burned when a Caddo structure was burned down and then covered with mound fill. Other remains came from a nearby midden that may mark a non-mound habitation deposit.

Finally, seven samples of pecan shell, cane matting, corn $(n=3)$, charred beans, and a carbonized persimmon seed were submitted for AMS radiocarbon dating as part of the reanalysis of the Eli Moores assemblage curated at TARL. The summed probability distribution of the seven calibrated radiocarbon dates indicate that the likeliest temporal range at two sigma (95 percent probability) of the Caddo occupation was between cal. A.D. 1400-1660, during the Texarkana phase. The major peaks in probability density are at ca. A.D. 1460-1520 and A.D. 1580-1640. The median calibrated age ranges span the period from A.D. 1403-1648. The calibrated age ranges with the highest probabilities from the charred matting/ pecan deposit in the mound are A.D. 1448-1530, A.D. 1487-1651, and A.D. 1620-1670, with median calibrated ages ranging from A.D. 1527-1648. This indicates this deposit dates to the latter years of the Texarkana phase, but before the historic Nasoni Caddo occupation of the Eli Moores site. The calibrated age ranges with the highest probabilities from the Item \#4 deposit in the mound are A.D. 1445-1522 (0.71), A.D. 1450-1524 (0.59), and A.D. 1541-1635 (0.53), with median calibrated ages ranging from A.D. 1487-1558. 


\section{References Cited}

Adovasio, J. W.

2010 Basketry Technology: A Guide to Identification and Analysis. Updated Edition. Left Coast Press. Walnut Creek, California.

Alt, S.

1999 Spindle Whorls and Fiber Production at Early Cahokian Settlements. Southeastern Archaeology 18(2):124-134.

Barr, J.

2007 Peace Came in the Form of a Woman: Indians and Spaniards in the Texas Borderlands. University of North Carolina Press, Chapel Hill.

2011 Geographies of Power: Mapping Indian Borders in the "Borderlands" of the Early Southwest. William and Mary Quarterly 68(1):5-46.

Bezanson, D.

2000 Natural Vegetation Types of Texas and Their Representation in Conservation Areas. Master's thesis, Department of Geography, University of Texas at Austin.

Bolton, H. E.

1987 The Hasinais: Southern Caddoans as seen by the earliest Europeans. University of Oklahoma Press, Norman.

Brown, J. A.

1996 The Spiro Ceremonial Center: The Archaeology of Arkansas Valley Caddoan Culture in Eastern Oklahoma. 2 Vols. Memoirs No. 29. Museum of Anthropology, University of Michigan, Ann Arbor.

Campbell, T. N.

1996 Nasoni Indians. In The New Handbook of Texas, Vol.4, edited by R. Tyler, pp. 938-939. Texas State Historical Association, Austin.

Core, H. A., W. A. Cote, and A. C. Day

1979 Wood Structure and Identification. 2nd edition. Syracuse University Press, Syracuse, New York.

Creel, D. G.

1996 Hatchel-Mitchell Site. In The New Handbook of Texas, Vol. 3, edited by R. Tyler, pp. 504-505. Texas State Historical Association, Austin.

Davis, L. W.

1993 Weed Seeds of the Great Plains: A Handbook for Identification. University Press of Kansas, Lawrence.

Diggs Jr., G. M., B. L. Lipscomb, M. D. Reed, and R. J. O'Kennon

2006 Illustrated Flora of East Texas, Volume One: Introduction, Pteridophytes, Gymnosperms, and Monocotyledons. Sida, Botanical Miscellany, No. 26. Botanical Research Institute of Texas, Fort Worth. 
Flynn, P.

1976 A Study of Red-Filmed Pottery from the Clement Site (Mc-8), McCurtain County, Oklahoma. Bulletin of the Oklahoma Anthropological Society 25:127-134.

Foster, W. C.

1995 Spanish Expeditions into Texas, 1689-1768. University of Texas Press, Austin.

2008 Historic Native Peoples of Texas. University of Texas Press, Austin.

Foster, W. C. (editor)

1998 The La Salle Expedition to Texas: The Journal of Henri Joutel, 1684-1687. Texas State Historical Association, Austin.

Galehouse, J. S.

1971 Point Counting. In Procedures in Sedimentary Petrology, edited by R. E. Carver, pp. 385-407. Wiley-Interscience, New York.

Gilmore, K.

1991 An Archeological Footnote to History. Bulletin of the Texas Archeological Society 60:303-324.

1996 Early European-Indian Ceremonies on the Red River. Journal of Northeast Texas Archaeology 7:12.

Good, C.

1977 Moores Plantation: Thesis Prospectus. MS on file, TARL.

Hatcher, M. A.

1927 Descriptions of the Tejas or Asinai Indians, 1691-1722, Part IV (Espinosa). Southwestern Historical Quarterly 31:150-180.

1932 The Expedition of Don Domingo Teran de los Rios into Texas. Preliminary Studies of the Texas Catholic Historical Society II(1):3-62.

1999 The Expedition of Don Domingo Teran de los Rios Into Texas (1691-1692). In Wilderness Mission: Preliminary Studies of the Texas Catholic Historical Society, edited by J. F. de la Teja, pp. 2-66. Studies in Southwestern Catholic History No. 2. Texas Catholic Historical Society, Austin.

Hoadley, R. B.

1990 Identifying Wood: Accurate Results with Simple Tools. The Taunton Press, Newtown, Connecticut.

Hoagland, B. W.

1998 [Riparian] Vegetation. In Riparian Area Management Handbook, edited by A. Fallon and M. Smolen, pp. 19-33. Oklahoma Cooperative Extension Service, Oklahoma State University, Stillwater.

Hoagland, B. W., L. R. Sorrets, and S. M. Glenn

1996 Woody Species Composition of Floodplain Forests of the Little River, McCurtain and LeFlore Counties, Oklahoma. Proceedings of the Oklahoma Academy of Sciences 76:23-29. 
InsideWood

2004-onwards Published on the Internet. http://insidewood.lib.ncsu.edu/search.

Jackson, A. T.

1932 Exploration of a Burial Site on E. H. Moores Plantation in Bowie County, Texas. MS on file, TARL.

2004 Excavation of an Earth Mound, Bowie County, Texas. Caddoan Archeology Journal 13 (No. 3/4):57-64.

Kelley, D. B.

2012 The Belcher Phase: Sixteenth- and Seventeenth-Century Caddo Occupation of the Red River Valley in Northwest Louisiana and Southwest Arkansas. In The Archaeology of the Caddo, edited by T. K. Perttula and C. P. Walker, pp. 411-430. University of Nebraska Press, Lincoln.

Kidd, K. E. and M. A. Kidd

1970 A Classification System for Glass Beads for the Use of Field Archaeologists. Occasional Papers in Archaeology and History 1:45-89. National Historic Sites Service, National and Historic Parks Branch, Department of Indian Affairs and Northern Development, Ottawa, Ontario.

Lee, $\mathrm{C}$.

1997 Paleopathology of the Hatchel-Mitchell-Moores Sites, Bowie County, Texas. Bulletin of the Texas Archeological Society 68:161-177.

Lee, M. B.

1945 An Ecological Study of the Floodplain Forest Along the White River System of Indiana. Butler University Botanical Studies 7:155-175.

MacRoberts, B. R. and M. H. MacRoberts

2008 Plant Ecology and Phytogeography of the West Gulf Coastal Plain: An Overview. In Freeman and Custis Red River Expedition of 1806: Two Hundred Years Later, edited by L. M. Hardy, pp. 7-28. Bulletin of the Museum of Life Sciences, No. 14. Museum of Life Sciences, Louisiana State University in Shreveport, Shreveport.

Martin, A. C. and W. D. Barkley

2000 Seed Identification Manual. The Blackburn Press, Caldwell, New Jersey.

Moore, C. B.

1912 Some Aboriginal Sites on Red River. Journal of the Academy of Natural Sciences of Philadelphia 14(4):526-638.

Musil, A. F.

1963 Identification of Crop and Weed Seeds Agriculture Handbook No. 219. U.S. Department of Agriculture, Washington, D.C.

NFIC (Natural Fibers Information Center)

1987 The Climates of Texas Counties. Natural Fibers Information Center, The University of Texas at Austin, in cooperation with the Office of the State Climatologist, Texas A\&M University, College Station. 
Panshin, A. J. and C. de Zeeuw

1980 Textbook of Wood Technology: Structure, Identification, Properties, and Uses of the Commercial Woods of the United States and Canada. Fourth edition. McGraw-Hill Book Company, New York.

Perttula, T. K.

1992 “The Caddo Nation”: Archaeological \& Ethnohistoric Perspectives. University of Texas Press, Austin.

2005 1938-1939 WPA Excavations at the Hatchel Site (41BW3) on the Red River in Bowie County, Texas. Southeastern Archaeology 24(2):180-198.

2013 Caddo Ceramics in East Texas. Bulletin of the Texas Archeological Society 84:181-212.

Perttula, T. K. and R. Z. Selden, Jr.

2011 East Texas Radiocarbon Database. Electronic resource, http://counciloftexasarcheologists. org/?page_id=27, July 1, 2013.

Perttula, T. K., J. E. Bruseth, N. A. Kenmotsu, and W. A. Martin

1995 Archeological Testing at the Cabe Mounds (41BW14), Bowie County, Texas. Cultural Resource Management Report 8. Department of Antiquities Protection, Texas Historical Commission, Austin.

Perttula, T. K., B. Nelson, R. L. Cast, and B. Gonzalez

2010 The Clements Site (41CS25): A Late 17 th to Early $18^{\text {th }}$-Century Nasoni Caddo Settlement and Cemetery. Anthropological Papers No. 92. American Museum of Natural History, New York.

Perttula, T. K., M. B. Trubitt, and J. S. Girard

2012 The Use of Shell-Tempered Pottery in the Caddo Area of the Southeastern United States. Southeastern Archaeology 30(2):242-267.

Phillips, P. and J. A. Brown

1978 Pre-Columbian Shell Engravings from the Craig Mound at Spiro, Oklahoma, Part 1. Peabody Museum Press, Peabody Museum of Archaeology and Ethnology, Harvard University, Cambridge.

Rice, P. M.

1987 Pottery Analysis: A Sourcebook. University of Chicago Press, Chicago.

Rogers, J. D. and G. Sabo III

2004 The Caddos. In Handbook of North American Indians, Volume 14, Southeast, edited by R. D. Fogelson, pp. 616-631. Smithsonian Institution, Washington, D.C.

Sabo, G. M.

2012 The Teran Map and Caddo Cosmology. In The Archaeology of the Caddo, edited by T. K. Perttula and C. P. Walker, pp. 431-447. University of Nebraska Press, Lincoln.

Schambach, F. F. and J. E. Miller

1984 A Description and Analysis of the Ceramics. In Cedar Grove: An Interdisciplinary Investigation of a Late Caddo Farmstead in the Red River Valley, edited by N. L. Trubowitz, pp. 109-170. Research Series No. 23. Arkansas Archeological Survey, Fayetteville. 
Scholtz, S. C.

1975 Prehistoric Plies: A Structural and Comparative Analysis of Cordage, Netting, Basketry, and Fabric from Ozark Bluff Shelters. Research Series No. 9. Arkansas Archeological Survey, Fayetteville.

Skinner, S. A., R. K. Harris, and K. M. Anderson (editors)

1969 Archaeological Investigations at the Sam Kaufman Site, Red River County, Texas. Contributions in Anthropology No. 5. Department of Anthropology, Southern Methodist University, Dallas.

Stoltman, J. B.

1989 A Quantitative Approach to the Petrographic Analysis of Ceramic Thin Sections. American Antiquity 54(1):147-160.

Story, D. A.

1990 Cultural History of the Native Americans. In The Archeology and Bioarcheology of the Gulf Coastal Plain, by D. A. Story, J. A. Guy, B. A. Burnett, M. D. Freeman, J. C. Rose, D. G. Steele, B. W. Olive, and K. J. Reinhard, pp. 163-366. 2 Vols. Research Series No. 38. Arkansas Archeological Survey, Fayetteville.

Sundermeyer, S. A., J. T. Penman, and T. K. Perttula

2008 Integrated Cultural Resources Investigations for the Bowie County Levee Realignment Project, Bowie County, Texas, and Little River County, Arkansas. Miscellaneous Reports, Report of Investigations No. 29. LopezGarcia Group, Dallas.

Taylor, H. C.

1949 An Archaeological Survey of the Mounds in the Red River from DeKalb, Texas, to Ida, Louisiana. MS on file, TARL.

Texas Archeological Research Laboratory, The University of Texas at Austin (TARL)

1931 University of Texas, Department of Anthropology Field Book \#1 for 1931. MS on file at TARL.

USDA, NRCS (United States Department of Agriculture, Natural Resources Conservation Service)

2013 The PLANTS Database. http://plants.usda.gov. National Plant Data Team, Greensboro, NC 274014901 USA. Accessed 12/19/13.

Wedel, M. M.

1978 La Harpe's 1719 Post on the Red River and Nearby Caddo Settlements. Bulletin No. 30. Texas Memorial Museum, Austin.

Webb, C. H.

1959 The Belcher Mound, a Stratified Caddoan Site in Caddo Parish, Louisiana. Memoirs No. 16. Society for American Archaeology, Salt Lake City.

Wheeler, E. A.

2011 InsideWood-A Web Resource for Hardwood Anatomy. IAWA Journal 32(2):199-211. 